CHPRC-01674

Revision 1

\title{
Hydrogen Concentration in the Inner-Most Container within a Pencil Tank Overpack Packaged in a Standard Waste Box Package
}

Prepared for the U.S. Department of Energy

Assistant Secretary for Environmental Management

Contractor for the U.S. Department of Energy

under Contract DE-AC06-08RL14788

C.M2N/HILL

Plateau Remediation Company

P.O. Box 1600

Richland, Washington 99352

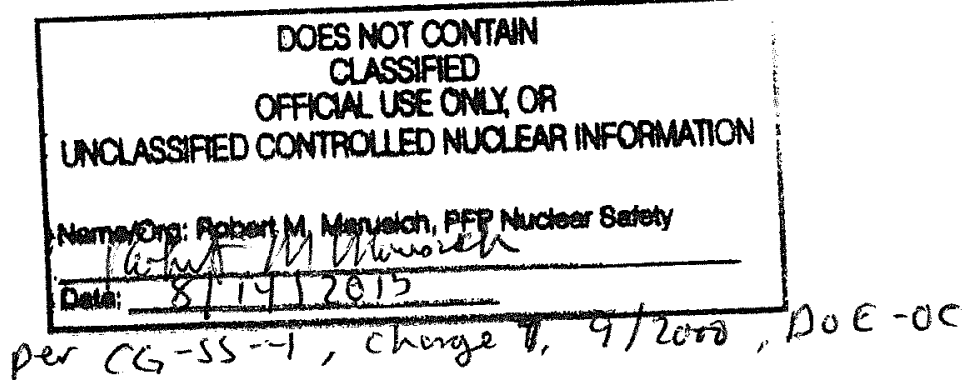


CHPRC-01674

Revision 1

EDC\#: ECR-13-000771

\section{Hydrogen Concentration in the Inner-Most Container within a Pencil Tank Overpack Packaged in a Standard Waste Box Package}

Document Type: TR Program/Project: PFP

R. M. Marusich

CH2M HILL Plateau Remediation Company

Date Published

August 2013

Prepared for the U.S. Department of Energy

Assistant Secretary for Environmental Management

Contractor for the U.S. Department of Energy

under Contract DE-AC06-08RL14788

\section{CH2WHILL}

Plateau Remediation Company

P.O. Box 1600

Richland, Washington 99352

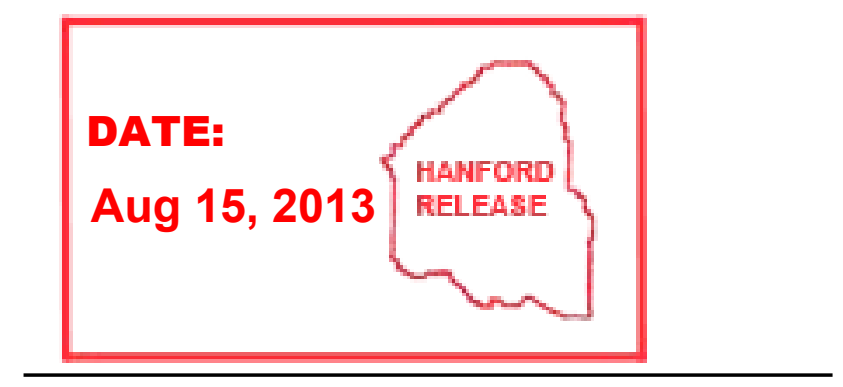

Release Stamp 


\section{CHPRC-01674}

Revision 1

TRADEMARK DISCLAIMER

Reference herein to any specific commercial product, process, or service by

tradename, trademark, manufacturer, or otherwise, does not necessarily

constitute or imply its endorsement, recommendation, or favoring by the

United States Government or any agency thereof or its contractors or

subcontractors.

This report has been reproduced from the best available copy.

Printed in the United States of America 


\section{CHPRC RECORD OF REVISION (ROR)}

(1) Document Number

CHPRC-01674

(2) Title

Hydrogen Concentration in the Inner-Most Container within a Pencil Tank Overpack Packaged in aa Standard Waste Box

\section{Change Control Record}

(3)

Revision

0

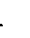

ECR-13-000771, Revised document, Revisions show hydrogen

concentration in the sonotube within Pencil Tanks in SWBs

already shipped and to show hydrogen concentration in the

sonotube for the case where the sonotube bag has a bag filter in

it and the sonotube cushon has an engineered hole in it (or the sonotube walls have engineered holes in them).
Authorized for Release

(5) DA/TA Date

Rivim i/15/70n

RMM

$8 \mid 1412013$

凶 


\title{
CHPRC-01674, Rev. 1
}

\section{Hydrogen Concentration in the Inner-Most Container Within a Pencil Tank Overpack Packaged in a Standard Waste Box Package}

\author{
August 2013 \\ Prepared by: R. M. Marusich \\ for \\ CH2M HILL Plateau Remediation Company \\ Richland, Washington
}




\section{Contents}

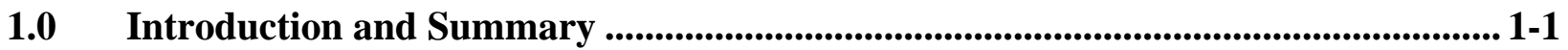

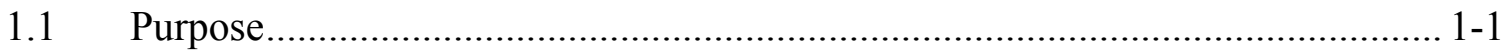

$1.2 \quad$ Methodology and Assumptions ............................................................. 1-2

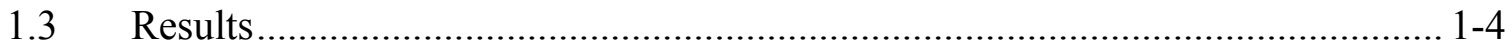

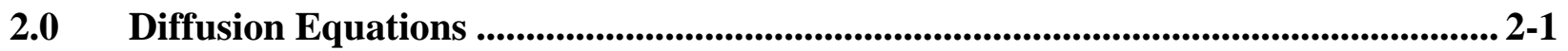

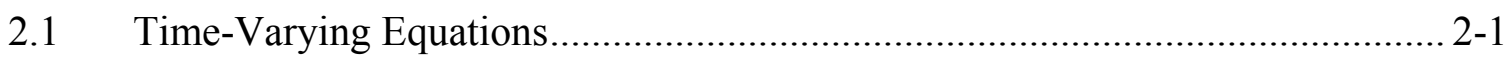

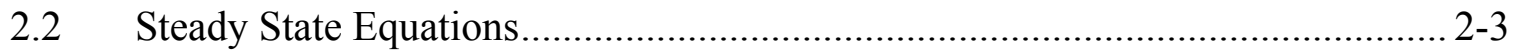

2.3 Method of Solution for Steady-State Equations …………............................. 2-4

3.0 Hydrogen Generation Rate ................................................................................................ 3-1

3.1 Number of Curies and Energy Released ....................................................... 3-1

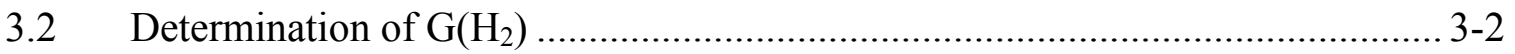

3.3 Hydrogen Generation Rate ………………............................................... 3-3

4.0 Permeability................................................................................................... 4-1

5.0 Permeability of "Horse-Tailed" or "Twist And Wrap" Closures ................................. 5-1

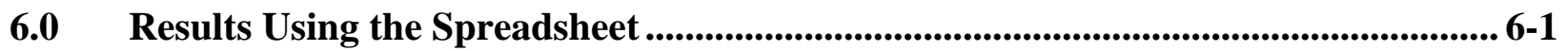

6.1 The 6-Bag Spreadsheet Used For the TRUCON Codes ...................................... 6-1

6.2 Hydrogen Diffusions in the PTO/SWB Waste Package ...................................... 6-1

6.2.1 Dimensions, Diffusivities and Initial Conditions of the PTO/SWB Waste Package ...................................................................................... 6-1

6.2.2 Hydrogen Concentration in the Sonotube of SWBs Previously

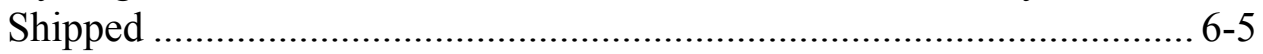

6.2.3 Hydrogen Concentration in the Sonotube of SWBs Shipped in the Future with a Bag Filer in the Sonotube Bag and with Hole in the Sonotube Cushion ........................................................................... 6-16

6.3 Miscellaneous Calculations ...................................................................... 6-20

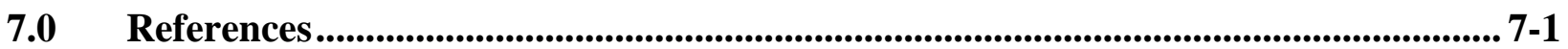

\section{Tables}

Table 1-1. Allowable Inventory for Various Configurations ............................................... 1-1

Table 3-1. Search Results for Specific Activity ................................................................ 3-2

Table 3-2. Calculation of the Average Energy per Disintegration......................................... 3-1

Table 3-3. Summary of G Values for alpha-emitting radionuclides from $\mathrm{CH}-\mathrm{TRU}$ Payload Appendices....................................................................................... 3-2 
Table 6-1. Bounding Mass Fraction of the Isotopes in the PTOs that have been Shipped ...... 6-5

Table 6-2. Inventory and Isotopic distribution for the SWBs containing PTOs that have

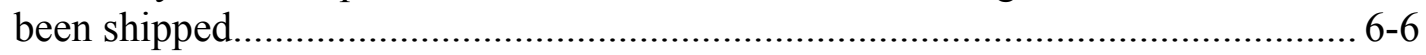

Table 6-3. Data on Water Vapor and Hydrogen Permeability .............................................. 6-11

Table 6-4. Diffusion through the PTO in an SWB waste package - Previously Shipped

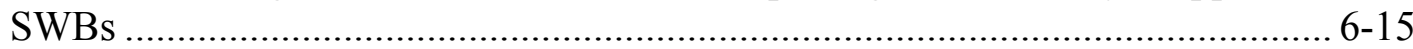

Table 6-5. Diffusion through the PTO in an SWB waste package - SWBs Shipped in the Future with a Bag Filter in the Sonotube Bag and with Holes in the Sonotube ................................................................................................ 6-19

Table 6-7. Resistance factors for various components of the PTO in an SWB .................... 6-22

\section{Figures}

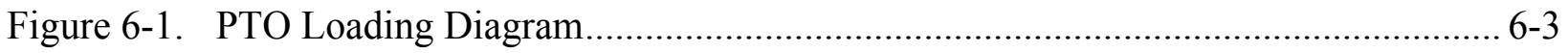

Figure 6-2. Sonotube Bag Sheet ................................................................................ 6-12

\section{Appendices}

A Details of the Steps Involved to Calculate the Hydrogen Concentration in the Sonotube using Steady State Diffusion Equations for the Pencil Tank Overpack .......... A-1

B Literature Search for Values for Permeability of Plastics .............................................

C A Literature Search for Values for Permeability of the Diffusivity of Twist and Tape Closures on Plastic Bags ........................................................................................

D E-Mail from Murthy Devarakonda, WIPP, Giving the Diffusivities Used by WIPP..... D-1

E Sensitivity Analyses Performed with 6-Bag Spreadsheet Modeling the TRUCON Code Configurations .................................................................................................

F Attachment from E-Mail Regarding Gram Limit Guidance for Debris Waste

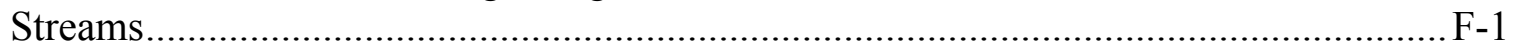

G Clarification of Data Used by WIPP in the Development of the TRUCON Code

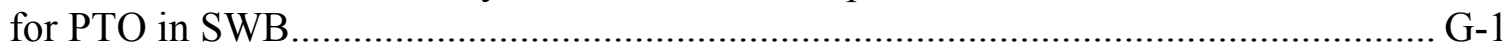

$\mathrm{H} \quad$ Equations Shown in the Spreadsheet .................................................................. H-1

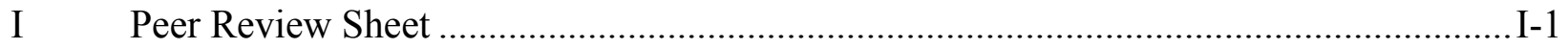




\section{Terms}

Am

DNFSB

DSA

MMC

NDA

NucFil

PFP

PRF

PTO

PVC

SWB

TBP

TRU

TRUCON

WIPP americium

Defense Nuclear Facility Safety Board

Documented Safety Analysis

Miscellaneous Material Container

Non-Destructive Assay

Nuclear Filter Technology

Plutonium Finishing Plant

Plutonium Reclamation Facility

Pencil Tank Overpack

polyvinyl chloride

Standard Waste Box

tributyl phosphate

Transuranic

TRU Waste Content

Waste Isolation Pilot Plant 


\subsection{Introduction and Summary}

\subsection{Purpose}

The purpose of this report is to evaluate hydrogen generation within Pencil Tank Overpacks (PTO) in a Standard Waste Box (SWB), to establish plutonium (Pu) limits for PTOs based on hydrogen concentration in the inner-most container and to establish required configurations or validate existing or proposed configurations for PTOs. The methodology and requirements are provided in this report.

This report:

- Provides information requested by the Defense Nuclear Facility Safety Board (DNFSB) staff for an argument and a technical basis which supports the position that the twist and tape closure method (a.k.a., "horse-tail") used on the plastic liners containing Transuranic (TRU) waste, provides a vent path which prevents the accumulation of flammable gas (e.g., hydrogen from radiolytic decomposition).

- Answers the questions that arose during the discussions with the DNFSB staff regarding hydrogen concentration in the Plutonium Finishing Plant (PFP)-specific waste package by developing a model to determine the hydrogen diffusion through multiple layers of confinement.

- Uses the model to show that:

- hydrogen concentration in a waste package for which there are TRU Waste Content (TRUCON) Codes (DOE/WIPP 01-3194, CH-TRU Waste Content Codes [CH-TRUCON], Rev 48) is less than 5 percent (thus showing that the model reasonably matched the Waste Isolation Pilot Plant [WIPP] calculations), and

- hydrogen concentration, within the sonotube that is inside the PTOs, which are within an SWB, is below 5 percent. 


\subsection{Methodology and Assumptions}

\section{Methodology}

A set of steady state diffusion flow equations, for the hydrogen diffusion from one bag to the next bag (or one plastic waste container to another), within a set of nested waste bags (or nested waste containers), are developed and presented. The input data is presented, justified, and input into the steady state diffusion flow equations, resulting in the steady state hydrogen concentration in each volume.

The input data is used in the equations for hydrogen concentration due to diffusion flow through multiple nested waste packages to obtain the hydrogen concentrations in the innermost portion of the waste package. The waste packages analyzed are designated by the TRUCON Code for the general waste containers, TRUCON Code RH125, and the TRUCON Code for the PTO in an SWB, TRUCON Code RH111S/112S. The TRUCON Codes come from DOE/WIPP 01-3194.

Figure 6-1, PTO Loading Diagram, depicts the packaging configuration for PTOs.

This packaging configuration is modeled with five regions, and a sixth designating the environment. The regions are:

- Region 1: Inside sonotube - void region inside the sonotube

- Region 2: Sonotube Bag - volume defined by outside of the sonotube and inside sonotube plastic bag

- Region 3: PTO - volume defined by outside of the sonotube plastic bag and inside PTO

- Region 4: SWB liner - volume defined by outside of PTO and inside of SWB liner

- Region 5: SWB liner - volume defined as outside the SWB liner and the inside of the SWB

- Region 6: Outside the SWB

\section{Assumptions}

The assumptions include the following:

- Waste package design data (dimensions, thicknesses, and materials of the various portions of the waste package) are as discussed in Section 6.2.1.

- Waste package diffusion data (diffusivity of the filters and permeability of the bag surface and closure, assumption of steady state conditions) are as discussed in Section 6.2.2 and 6.2.3.

- Value of $\mathrm{G}\left(\mathrm{H}_{2}\right)$ and isotopic distribution is that shown in Section 3.2 and 6.2.2.

- Plutonium values used in the analysis are best estimate values from the Non-Destructive Analysis (NDA). Best estimate values are used as they are most representative of the inventory that is generating hydrogen. 
- It is assumed that the plutonium isotopes are encased in material that results in the greatest hydrogen generation; solidified aqueous or homogeneous inorganic solids or high-wattage solid organic materials with absorbed liquids (See Section 3.2 and 6.2.2).

- In each case, all of the PTOs were assumed to be the small PTOs, per Section 6.2.1. This is a conservative assumption for the six-PTO case (usually four small PTOs and two large PTOs in an SWB) and could be conservative for the other cases if the pencil tank sections are such that the large PTO is used.

- The inventory in each PTO was chosen so that the hydrogen concentration in the sonotube was 4.8 percent (i.e., less than 5 percent with some margin).

- It is assumed that each PTO in an SWB has the same amount of plutonium. The assumption is conservative. In reality, PTOs are mixed into SWBs in order to minimize the number of PTOs. This sometimes results in PTOs with over 100 grams Pu being surrounded by PTOs with less than 25 grams Pu.

\section{Flow of Report}

Section 2.0 provides the set of equations that were solved to determine the hydrogen concentration in the various portions of the waste package of interest. Section 2.0 also provides the method of solutions of these equations. Sections 3.0, 4.0, and 5.0 provide the input needed to solve the diffusion equation, that is, the hydrogen generation rate, the permeability of hydrogen through the bag surface, and the diffusivity of hydrogen through the twist and tape closures ("horse-tails"). Sections 2.0 through 5.0 are essentially unchanged from that in Revision 0 to CHPRC-01674.

Section 6.0 provides the results from the spreadsheet analysis. The method is first tested by showing that the hydrogen concentration in the innermost bag within a set of bags, used to package general waste allowed by WIPP for a particular TRUCON Code for general debris shipments, is less than 5 percent of the allowable inventory. The method is then used to show the hydrogen concentration in the PTO/SWB package. Section 6.0 and 6.1 are essentially unchanged from that in Revision 0 to CHPRC-01674. Section 6.2 provides the new analysis of the hydrogen concentration within SWBs that have been previously shipped and new analysis of the hydrogen concentration within SWBs given the changes to the sonotube and sonotube bag.

The appendices contain the details of the analytical method used to calculate the hydrogen concentration and the justification of the input data used. The equations and the method solutions were coded into a spreadsheet. Appendix A, Details of the Steps Involved to Calculate the Hydrogen Concentration in the Sonotube using Steady State Diffusion Equations for the Pencil Tank Overpack, shows the equations coded into the spreadsheet. Appendix H, Equations Shown in the Spreadsheet, provides the details of the spreadsheet.

Appendices A through $\mathrm{F}$ and Appendix $\mathrm{H}$ are essentially unchanged from that in Revision 0 to CHPRC-01674. Appendix G.2 of Revision 1 now contains additional e-mail correspondence from WIPP regarding the sonotube bag. 


\subsection{Results}

Table 1-1, Allowable Inventory for Various Configurations, provides the allowable inventory in PTOs for SWBs that have been shipped and SWBs that will be shipped in the future. The difference between the PTOs within the SWBs that have been shipped and those to be shipped is the following:

- In most cases, the sonotube cushion in the SWBs to be shipped contains a PVC pipe nipple that is 2.25-inch in diameter and has a 2.75-inch long hole to provide an engineered path for hydrogen out of the sonotube. In some cases, the sonotubes contain four 0.5 -inch diameter holes near the base. The diffusivity of the 2.25-inch diameter hole in the sonotube cushion is slightly smaller to that of the four 0.5 -inch diameter holes. The sonotube in the SWBs that have been shipped do not have the engineered flow path. Hydrogen diffusion is through the gap between the sonotube cushion and the sonotube wall and between the wood plug and the sonotube wall.

- The sonotube bag in the SWBs to be shipped contains a bag filter as well as a twist and tape closure. The sonotube bags in the SWBs that have been shipped contain only the twist and tape closure.

- The isotopic inventory of the material in the pencil tanks of the SWBs that have been shipped is assumed to be a "fuels grade" isotopic distribution. "Fuels grade" plutonium was the most restrictive (in terms of hydrogen generation) of the solutions that were run through the pencil tanks. The isotopic inventory of the material within the SWB to be shipped is based on a bounding distribution taken from the PFP Documented Safety Analysis (DSA) (HNF-15500, Plutonium Finishing Plant Deactivation and

Decommissioning Documented Safety Analysis). The bounding distribution is used to be conservative and to cover the very unlikely event that an isotopic distribution more severe than the "fuels grade" distribution may be encountered. Use of the bounding isotopic distribution results in allowable inventories that are $25 \%$ to $30 \%$ less than those obtained using a "fuels grade" isotopic distribution.

Table 1-1 also shows that the allowable inventory in the SWBs to be shipped are bounded by the 325 fissile gram equivalent limit (based on best estimate NDA measurement plus two sigma) imposed by WIPP and the PFP Criticality Safety Evaluation Report. 
Table 1-1. Allowable Inventory for Various Configurations

\begin{tabular}{|c|c|c|c|c|c|c|c|c|c|}
\hline \multirow{2}{*}{ Title } & \multirow{2}{*}{$\mathbf{G}\left(\mathbf{H}_{2}\right)$} & \multirow{2}{*}{$\begin{array}{c}\text { Isotopic } \\
\text { Distribution }\end{array}$} & \multicolumn{3}{|c|}{$\begin{array}{l}\text { Allowable inventory for the } \\
\text { indicated number of PTOs }\end{array}$} & \multicolumn{4}{|c|}{ Diffusivity } \\
\hline & & & 1 & 3 & 6 & sonotube & $\begin{array}{c}\text { Sonotube } \\
\text { bag }\end{array}$ & PTO & SWB \\
\hline SWBs previously shipped & 1.09 & "Fuels grade" & 218 & 194 & 165 & $1.03 \mathrm{E}-5$ & $4.67 \mathrm{E}-6$ & $1.1 \mathrm{E}-5$ & $3.7 \mathrm{E}-5$ \\
\hline $\begin{array}{l}\text { SWBs to be shipped. } \\
\text { 2.25-inch diameter, } 2.75 \text { inch } \\
\text { long hole in sonotube cushion } \\
\text { (representing a 2.5-inch } \\
\text { Schedule } 80 \text { PVC fully threaded } \\
\text { pipe nipple). } \\
\text { (Sonotubes that have four } 0.5 \\
\text { inch diameter holes in the } \\
\text { sonotube wall, instead of a } 2.25 \text { - } \\
\text { inch hole in the sonotube } \\
\text { cushion have the same } \\
\text { allowable inventory) }\end{array}$ & 1.6 & ">10\% Pu-240" & 331 & 237 & 166 & $1.13 \mathrm{E}-4$ & $1.1 \mathrm{E}-4$ & $1.1 \mathrm{E}-5$ & $3.7 \mathrm{E}-5$ \\
\hline Bag filter in sonotube bag. & & & & & & & & & \\
\hline
\end{tabular}




\subsection{Diffusion Equations}

Before the hydrogen concentration located within the PTO in an SWB can be analyzed, a set of equations for the hydrogen diffusion through nested waste containers must be determined. The equations used and the method of the solution of the inter-related equations are developed within this section.

\subsection{Time-Varying Equations}

Equations 1 and 2 of ICP/CON-04-00563, High Hydrogen Concentrations Detected In The Underground Vaults For RH-TRU Waste At INEEL Compared With Calculated Values Using The INEEL-Developed Computer Code, provide the general equations for the hydrogen transport through the nested waste packages. The equations are extended to cover a case in which there is a six-bag (or six-container) nested waste package (e.g., Bag 1 is in Bag 2, Bag 2 is in Bag 3, etc.) within a liner in a drum or an SWB. The equations for a nested six-bag package in a liner within a drum represent the worst-case package for which there is a TRUCON Code at Hanford.

The equations are shown below. Subscripts 1 through 6 denote the nested bags. The bags can be waste bags or other containers (i.e., metal material containers). Subscript "L" denotes the liner and subscript " $D$ " denotes the drum. The terms are defined after the equations are set forth.

The equation for the innermost bag is:

$$
\frac{\mathrm{dn}_{\mathrm{H} 2,1}}{\mathrm{dt}}=\mathrm{n}_{\mathrm{H} 2, \mathrm{Gen}}-\mathrm{L}_{\mathrm{R}, 1 \rightarrow 2}\left(\frac{\mathrm{n}_{\mathrm{H} 2,1}}{\mathrm{n}_{\mathrm{T}, 1}}-\frac{\mathrm{n}_{\mathrm{H} 2,2}}{\mathrm{n}_{\mathrm{T}, 2}}\right)
$$

The equations for bags 2 through 5 (i.e., $\mathrm{j}=2$ through 5) are:

$$
\frac{\mathrm{dn}_{\mathrm{H} 2, \mathrm{j}}}{\mathrm{dt}}=\left\{\left(\mathrm{L}_{\mathrm{R},(\mathrm{j}-1) \rightarrow \mathrm{j}}\right)\left(\frac{\mathrm{n}_{\mathrm{H} 2,(\mathrm{j}-1)}}{\mathrm{n}_{\mathrm{T},(\mathrm{j}-1)}}-\frac{\mathrm{n}_{\mathrm{H} 2, \mathrm{j}}}{\mathrm{n}_{\mathrm{T}, \mathrm{j}}}\right)\right\}-\left\{\left(\mathrm{L}_{\mathrm{R}, \mathrm{j} \rightarrow(\mathrm{j}+1)}\right)\left(\frac{\mathrm{n}_{\mathrm{H} 2, \mathrm{j}}}{\mathrm{n}_{\mathrm{T}, \mathrm{j}}}-\frac{\mathrm{n}_{\mathrm{H} 2,(\mathrm{j}+1)}}{\mathrm{n}_{\mathrm{T},(\mathrm{j}+1)}}\right)\right\}
$$

The equation for the last bag $(\mathrm{j}=6$ - flow into the Liner) is:

$$
\frac{\mathrm{dn}_{\mathrm{H} 2,6}}{\mathrm{dt}}=\left\{\left(\mathrm{L}_{\mathrm{R},(5) \rightarrow 6}\right)\left(\frac{\mathrm{n}_{\mathrm{H} 2,(5)}}{\mathrm{n}_{\mathrm{T},(5)}}-\frac{\mathrm{n}_{\mathrm{H} 2,6}}{\mathrm{n}_{\mathrm{T}, 6}}\right)\right\}-\left\{\left(\mathrm{L}_{\mathrm{R}, 6 \rightarrow(\mathrm{L})}\right)\left(\frac{\mathrm{n}_{\mathrm{H} 2,6}}{\mathrm{n}_{\mathrm{T}, 6}}-\frac{\mathrm{n}_{\mathrm{H} 2,(\mathrm{~L})}}{\mathrm{n}_{\mathrm{T},(\mathrm{L})}}\right)\right\}
$$


The equations for the Liner and the Drum are:

$$
\begin{gathered}
\frac{\mathrm{dn}_{\mathrm{H} 2, \mathrm{~L}}}{\mathrm{dt}}=\left\{\left(\mathrm{L}_{\mathrm{R},(6) \rightarrow \mathrm{L}}\right)\left(\frac{\mathrm{n}_{\mathrm{H} 2,(6)}}{\mathrm{n}_{\mathrm{T},(6)}}-\frac{\mathrm{n}_{\mathrm{H} 2, \mathrm{~L}}}{\mathrm{n}_{\mathrm{T}, \mathrm{L}}}\right)\right\}-\left\{\left(\mathrm{L}_{\mathrm{R}, \mathrm{L} \rightarrow(\mathrm{D})}\right)\left(\frac{\mathrm{n}_{\mathrm{H} 2, \mathrm{~L}}}{\mathrm{n}_{\mathrm{T}, \mathrm{L}}}-\frac{\mathrm{n}_{\mathrm{H} 2,(\mathrm{D})}}{\mathrm{n}_{\mathrm{T},(\mathrm{D})}}\right)\right\} \\
\frac{\mathrm{dn}_{\mathrm{H} 2, \mathrm{D}}}{\mathrm{dt}}=\left\{\left(\mathrm{L}_{\mathrm{R},(\mathrm{L}) \rightarrow \mathrm{D}}\right)\left(\frac{\mathrm{n}_{\mathrm{H} 2,(\mathrm{~L})}}{\mathrm{n}_{\mathrm{T},(\mathrm{L})}}-\frac{\mathrm{n}_{\mathrm{H} 2, \mathrm{D}}}{\mathrm{n}_{\mathrm{T}, \mathrm{D}}}\right)\right\}-\left\{\left(\mathrm{L}_{\mathrm{R}, \mathrm{D} \rightarrow \text { atmos }}\right)\left(\frac{\mathrm{n}_{\mathrm{H} 2, \mathrm{D}}}{\mathrm{n}_{\mathrm{T}, \mathrm{D}}}-\frac{\mathrm{n}_{\mathrm{H} 2, \text { atmos }}}{\mathrm{n}_{\mathrm{T}, \text { atmos }}}\right)\right\}
\end{gathered}
$$

The equation for the hydrogen transport rate from package " $\mathrm{i}$ " to package " $\mathrm{i}+1$ " is defined as:

$$
L_{R, i,(i+1)}=\frac{P * A * C *(76 \text { cmHg per mole frac.) }}{x}(\text { where } i=1 \text { to } 6 \text { or "L" or " } D \text { ") }
$$

where:

$$
\begin{aligned}
& \mathrm{n}_{\mathrm{H} 2, \mathrm{I}}=\text { moles of hydrogen in a bag, liner, or drum ( } \mathrm{i}=1 \text { to } 6 \text { or "L" or " } \mathrm{D} \text { ") } \\
& \mathrm{n}_{\mathrm{T}, \mathrm{i}}=\text { total moles of gas in a bag, liner, or drum ( } \mathrm{i}=1 \text { to } 6 \text { or " } \mathrm{L} \text { " or " } \mathrm{D} \text { ") } \\
& \mathrm{t}=\text { time, seconds } \\
& \mathrm{n}_{\mathrm{H} 2, \mathrm{atmos}}=\text { hydrogen concentration of the atmosphere }=0.0 \\
& \mathrm{n}_{\mathrm{H} 2, \mathrm{Gen}}=\text { hydrogen generation rate, moles/s } \\
& \mathrm{L}_{\mathrm{R}, \mathrm{i},(\mathrm{i}+1)}=\quad \text { hydrogen transport rate from package } \mathrm{i} \text { to } \mathrm{i}+1 \text { (where } \mathrm{i}=1 \text { to } 6 \text { or " } \mathrm{L} \text { " or } \\
& \text { " } \mathrm{D} \text { "), or filter permeability, in units of moles/s-mole fraction, if a filter is } \\
& \text { present rather than diffusion flow through a bag. (See below) } \\
& \mathrm{P}=\text { hydrogen gas permeability, } \mathrm{cm}^{3}(\mathrm{STP}) / \mathrm{s}-\mathrm{cm}-\mathrm{cmHg} \text { (For this document, the } \\
& \text { more common and equivalent units are used. The more common units are: } \\
& \mathrm{cm}^{3}-\mathrm{cm} / \mathrm{s}-\mathrm{cm}^{2}-\mathrm{cmHg} \text { ) } \\
& \mathrm{A}=\text { layer (bag) permeable area, } \mathrm{cm}^{2} \\
& \mathrm{x}=\text { bag thickness, } \mathrm{cm} \\
& \mathrm{C}=\text { conversion factor for moles } / \mathrm{cm}^{3} \\
& =4.1 \times 10^{-5} \text { moles } / \mathrm{cm}^{3} \text { at } 298 \mathrm{~K} \text { and } 1 \text { atm per the ideal gas law. }
\end{aligned}
$$

The waste packages and containers are assumed to always be at atmospheric pressure (no pressurization due to hydrogen generation).

As is shown above, the hydrogen transport rate is a function of the permeability of the material, the material thickness, and the area of the material. For a waste package, there are multiple components to the transport rate. Consider a waste bag with a twist and tape closure. There is diffusion through the single layer of the bag surface, through the multiple layers of the bag 
material used in the twisted portion of the closure, through the multiple layers of the bag material, and the tape in the twisted portion of the closure that is taped.

For the purposes of this paper, the portions of the waste package are assumed to be comprised of a single layer of material and a closure (e.g., twist and tape). The "area" is the surface area of the portion of the waste package. The diffusivity of the closure is determined separately and added to the calculated diffusivity of the surface area. The "thickness" is the thickness of the material comprising the portion of the waste package (e.g., a single layer of the bag material). The "hydrogen gas permeability" is the permeability of the bag material to the hydrogen gas. Tape, which might be placed on the portion of the waste package surface outside of the closure, is ignored as the area of the tape and the underlying bag material is assumed to be much smaller than the area of the non-taped area. The transport rate of the closure is assumed to be from the tests (See Section 5.0).

\subsection{Steady State Equations}

In the analyses that follow, the time-varying equations are not used. Instead, since the steady state hydrogen concentration is required, the steady-state equations are used. To obtain the steady state equations, the time-varying equations above are used, but with the term $\mathrm{dn}_{\mathrm{H} 2, \mathrm{i}} / \mathrm{dt}$, (where $\mathrm{i}=1$ to 6 or "L" or " $\mathrm{D}$ ") set equal to zero.

Steady-State Equation for innermost bag:

$$
\mathrm{n}_{\mathrm{H} 2, \mathrm{Gen}}=\mathrm{L}_{\mathrm{R}, 1 \rightarrow 2}\left(\frac{\mathrm{n}_{\mathrm{H} 2,1}}{\mathrm{n}_{\mathrm{T}, 1}}-\frac{\mathrm{n}_{\mathrm{H} 2,2}}{\mathrm{n}_{\mathrm{T}, 2}}\right)
$$

Steady-State Equations for bags 2 through $6(j=2$ through 5):

$$
\left\{\left(\mathrm{L}_{\mathrm{R},(\mathrm{j}-1) \rightarrow \mathrm{j}}\right)\left(\frac{\mathrm{n}_{\mathrm{H} 2,(\mathrm{j}-1)}}{\mathrm{n}_{\mathrm{T},(\mathrm{j}-1)}}-\frac{\mathrm{n}_{\mathrm{H} 2, \mathrm{j}}}{\mathrm{n}_{\mathrm{T}, \mathrm{j}}}\right)\right\}=\left\{\left(\mathrm{L}_{\mathrm{R}, \mathrm{j} \rightarrow(\mathrm{j}+1)}\right)\left(\frac{\mathrm{n}_{\mathrm{H} 2, \mathrm{j}}}{\mathrm{n}_{\mathrm{T}, \mathrm{j}}}-\frac{\mathrm{n}_{\mathrm{H} 2,(\mathrm{j}+1)}}{\mathrm{n}_{\mathrm{T},(\mathrm{j}+1)}}\right)\right\}
$$

$(j=6$ - Flow from bag 6 to the Liner):

$$
\left\{\left(\mathrm{L}_{\mathrm{R},(5) \rightarrow 6}\right)\left(\frac{\mathrm{n}_{\mathrm{H} 2,5}}{\mathrm{n}_{\mathrm{T},(5)}}-\frac{\mathrm{n}_{\mathrm{H} 2,6}}{\mathrm{n}_{\mathrm{T}, 6}}\right)\right\}=\left\{\left(\mathrm{L}_{\mathrm{R}, 6 \rightarrow(\mathrm{L})}\right)\left(\frac{\mathrm{n}_{\mathrm{H} 2,6}}{\mathrm{n}_{\mathrm{T}, 6}}-\frac{\mathrm{n}_{\mathrm{H} 2,(\mathrm{~L})}}{\mathrm{n}_{\mathrm{T},(\mathrm{L})}}\right)\right\}
$$


Steady-State Equations for the Liner and Drum:

$$
\begin{gathered}
\left\{\left(\mathrm{L}_{\mathrm{R},(6) \rightarrow \mathrm{L}}\right)\left(\frac{\mathrm{n}_{\mathrm{H} 2,(6)}}{\mathrm{n}_{\mathrm{T},(6)}}-\frac{\mathrm{n}_{\mathrm{H} 2, \mathrm{~L}}}{\mathrm{n}_{\mathrm{T}, \mathrm{L}}}\right)\right\}=\left\{\left(\mathrm{L}_{\mathrm{R}, \mathrm{L} \rightarrow(\mathrm{D})}\right)\left(\frac{\mathrm{n}_{\mathrm{H} 2, \mathrm{~L}}}{\mathrm{n}_{\mathrm{T}, \mathrm{L}}}-\frac{\mathrm{n}_{\mathrm{H} 2,(\mathrm{D})}}{\mathrm{n}_{\mathrm{T}, \mathrm{D})}}\right)\right\} \\
\left\{\left(\mathrm{L}_{\mathrm{R},(\mathrm{L}) \rightarrow \mathrm{D}}\right)\left(\frac{\mathrm{n}_{\mathrm{H} 2, \mathrm{~L})}}{\mathrm{n}_{\mathrm{T}, \mathrm{L})}}-\frac{\mathrm{n}_{\mathrm{H} 2, \mathrm{D}}}{\mathrm{n}_{\mathrm{T}, \mathrm{D}}}\right)\right\}=\left\{\left(\mathrm{L}_{\mathrm{R}, \mathrm{D} \rightarrow \text { atmos }}\right)\left(\frac{\mathrm{n}_{\mathrm{H} 2, \mathrm{D}}}{\mathrm{n}_{\mathrm{T}, \mathrm{D}}}-\frac{\mathrm{n}_{\mathrm{H} 2, \mathrm{atmos}}}{\mathrm{n}_{\mathrm{T}, \text { atmos }}}\right)\right\}
\end{gathered}
$$

\subsection{Method of Solution for Steady-State Equations}

The steady-state equations are solved as follows: (See also Appendix A for a step-by-step method of solution for the particular case of hydrogen flow through the components on the PTO into the SWB.)

Let the term " $\mathrm{i} \rightarrow \mathrm{j}$ " stand for the term in the braces. For example:

$$
2 \rightarrow 3 \equiv\left\{\left(\mathrm{L}_{\mathrm{R}, 2 \rightarrow(3)}\right)\left(\frac{\mathrm{n}_{\mathrm{H} 2,2}}{\mathrm{n}_{\mathrm{T}, 2}}-\frac{\mathrm{n}_{\mathrm{H} 2,(3)}}{\mathrm{n}_{\mathrm{T},(3)}}\right)\right\}
$$

The steady state equations are recast using this shorthand. The result is:

$$
\begin{gathered}
\mathrm{n}_{\mathrm{H} 2, \mathrm{Gen}}=1 \rightarrow 2 \\
1 \rightarrow 2=2 \rightarrow 3 \\
2 \rightarrow 3=3 \rightarrow 4 \\
3 \rightarrow 4=4 \rightarrow 5 \\
4 \rightarrow 5=5 \rightarrow 6 \\
5 \rightarrow 6=6 \rightarrow 7 \\
6 \rightarrow 7=7 \rightarrow 8 \\
7 \rightarrow 8=8 \rightarrow \text { atmos }
\end{gathered}
$$

Solving this set of equations yields:

$$
\mathrm{n}_{\mathrm{H} 2, \mathrm{Gen}}=8 \rightarrow \text { atmos }
$$


Substituting the term that " $8 \rightarrow$ atmos" stands for, one obtains:

$$
\mathrm{n}_{\mathrm{H} 2, \mathrm{Gen}}=\mathrm{L}_{\mathrm{R}, \mathrm{D} \rightarrow \operatorname{atmos}}\left(\frac{\mathrm{n}_{\mathrm{H} 2, \mathrm{D}}}{\mathrm{n}_{\mathrm{T}, \mathrm{D}}}-\frac{\mathrm{n}_{\mathrm{H} 2, \mathrm{atmos}}}{\mathrm{n}_{\mathrm{T}, \mathrm{atmos}}}\right)
$$

where the subscript "D" stands for the drum.

Since $\mathrm{n}_{\mathrm{H} 2 \text {,atmos }}=0.0$ and $\mathrm{n}_{\mathrm{T}, \text { atmos }}$ is based on a very large volume, the last term in the parenthesis is set equal to 0.0 . Using this fact,

$$
\begin{gathered}
\mathrm{n}_{\mathrm{H} 2, \mathrm{Gen}}=\mathrm{L}_{\mathrm{R}, \mathrm{L} \rightarrow \operatorname{atmos}}\left(\frac{\mathrm{n}_{\mathrm{H} 2, \mathrm{D}}}{\mathrm{n}_{\mathrm{T}, \mathrm{D}}}-0.0\right) \\
\text { or } \\
\frac{\mathrm{n}_{\mathrm{H} 2, \mathrm{Gen}}}{\mathrm{L}_{\mathrm{R}, \mathrm{D} \rightarrow \text { atmos }}}=\left(\frac{\mathrm{n}_{\mathrm{H} 2, \mathrm{D}}}{\mathrm{n}_{\mathrm{T}, \mathrm{D}}}\right)
\end{gathered}
$$

The term in parenthesis is the mole fraction of the hydrogen in the drum. It is evaluated by putting in the numerical values for $\mathrm{n}_{\mathrm{H} 2 \text {,Gen }}$ and $\mathrm{L}_{\mathrm{R}, \mathrm{D} \rightarrow \text { atmos, }}$, which, in this case, is the filter diffusivity.

The mole fraction in the next to the last barrier (the Liner), is found using the value of the mole fraction of the drum. The general equation for the drum (where " $\mathrm{D}$ " stands for the last portion of the waste package or the drum) is:

$$
\left\{\left(\mathrm{L}_{\mathrm{R}, \mathrm{L}) \rightarrow \mathrm{D}}\right)\left(\frac{\mathrm{n}_{\mathrm{H} 2, \mathrm{~L})}}{\mathrm{n}_{\mathrm{T}, \mathrm{L})}}-\frac{\mathrm{n}_{\mathrm{H} 2, \mathrm{D}}}{\mathrm{n}_{\mathrm{T}, \mathrm{D}}}\right)\right\}=\left\{\left(\mathrm{L}_{\mathrm{R}, \mathrm{D} \rightarrow(\text { atmos })}\right)\left(\frac{\mathrm{n}_{\mathrm{H} 2, \mathrm{D}}}{\mathrm{n}_{\mathrm{T}, \mathrm{D}}}-\frac{\mathrm{n}_{\mathrm{H} 2, \mathrm{atmos}}}{\mathrm{n}_{\mathrm{T},(\mathrm{atmos})}}\right)\right\}
$$


Solving for the mole fraction of the liner yields:

$$
\frac{\mathrm{n}_{\mathrm{H} 2, \mathrm{~L})}}{\mathrm{n}_{\mathrm{T}, \mathrm{L})}}=\frac{\left\{\left(\mathrm{L}_{\mathrm{R}, \mathrm{D} \rightarrow(\text { atmos })}\right)\left(\frac{\mathrm{n}_{\mathrm{H} 2, \mathrm{D}}}{\mathrm{n}_{\mathrm{T}, \mathrm{D}}}-0\right)\right\}+\left(\mathrm{L}_{\mathrm{R},(\mathrm{L}) \rightarrow \mathrm{D}}\right)\left(\frac{\mathrm{n}_{\mathrm{H} 2, \mathrm{D}}}{\mathrm{n}_{\mathrm{T}, \mathrm{D}}}\right)}{\mathrm{L}_{\mathrm{R}, \mathrm{L}) \rightarrow \mathrm{D}}}
$$

or

$$
\frac{\mathrm{n}_{\mathrm{H} 2,(\mathrm{~L})}}{\mathrm{n}_{\mathrm{T}, \mathrm{L})}}=\frac{\mathrm{n}_{\mathrm{H} 2, \mathrm{D}}}{\mathrm{n}_{\mathrm{T}, \mathrm{D}}}+\left\{\left(\frac{\mathrm{L}_{\mathrm{R}, \mathrm{D} \rightarrow(\text { atmos })}}{\mathrm{L}_{\mathrm{R},(\mathrm{L}) \rightarrow \mathrm{D}}}\right)\left(\frac{\mathrm{n}_{\mathrm{H} 2, \mathrm{D}}}{\mathrm{n}_{\mathrm{T}, \mathrm{D}}}-\frac{\mathrm{n}_{\mathrm{H} 2, \text { atmos }}}{\mathrm{n}_{\mathrm{T},(\mathrm{atmos})}}\right)\right\}
$$

The hydrogen mole fractions for the other bags are found using the general equation for the remainder of the portions of the waste package. The general equation is:

The mole fraction within the outer-most of the bag is found from the following:

$$
\left\{\left(\mathrm{L}_{\mathrm{R},(\mathrm{K}) \rightarrow \mathrm{L}}\right)\left(\frac{\mathrm{n}_{\mathrm{H} 2,(\mathrm{~K})}}{\mathrm{n}_{\mathrm{T},(\mathrm{K})}}-\frac{\mathrm{n}_{\mathrm{H} 2, \mathrm{~L}}}{\mathrm{n}_{\mathrm{T}, \mathrm{L}}}\right)\right\}=\left\{\left(\mathrm{L}_{\mathrm{R}, \mathrm{L} \rightarrow(\mathrm{D})}\right)\left(\frac{\mathrm{n}_{\mathrm{H} 2, \mathrm{~L}}}{\mathrm{n}_{\mathrm{T}, \mathrm{L}}}-\frac{\mathrm{n}_{\mathrm{H} 2,(\mathrm{D})}}{\mathrm{n}_{\mathrm{T},(\mathrm{D})}}\right)\right\} \text { where } \mathrm{K}=6
$$

Solving yields

$$
\frac{\mathrm{n}_{\mathrm{H} 2,(\mathrm{~K})}}{\mathrm{n}_{\mathrm{T},(\mathrm{K})}}=\frac{\mathrm{n}_{\mathrm{H} 2, \mathrm{~L}}}{\mathrm{n}_{\mathrm{T}, \mathrm{L}}}+\left\{\left(\frac{\mathrm{L}_{\mathrm{R}, \mathrm{L} \rightarrow(\mathrm{D})}}{\mathrm{L}_{\mathrm{R},(\mathrm{K}) \rightarrow \mathrm{L}}}\right)\left(\frac{\mathrm{n}_{\mathrm{H} 2, \mathrm{~L}}}{\mathrm{n}_{\mathrm{T}, \mathrm{L}}}-\frac{\mathrm{n}_{\mathrm{H} 2, \mathrm{D}}}{\mathrm{n}_{\mathrm{T}, \mathrm{D}}}\right)\right\}
$$

The mole fraction in any of the other five bags is found using the following equation:

$$
\left\{\left(\mathrm{L}_{\mathrm{R},(\mathrm{K}-1) \rightarrow \mathrm{K}}\right)\left(\frac{\mathrm{n}_{\mathrm{H} 2,(\mathrm{~K}-1)}}{\mathrm{n}_{\mathrm{T},(\mathrm{K}-1)}}-\frac{\mathrm{n}_{\mathrm{H} 2, \mathrm{~K}}}{\mathrm{n}_{\mathrm{T}, \mathrm{K}}}\right)\right\}=\left\{\left(\mathrm{L}_{\mathrm{R}, \mathrm{K} \rightarrow(\mathrm{K}+1)}\right)\left(\frac{\mathrm{n}_{\mathrm{H} 2, \mathrm{~K}}}{\mathrm{n}_{\mathrm{T}, \mathrm{K}}}-\frac{\mathrm{n}_{\mathrm{H} 2,(\mathrm{~K}+1)}}{\mathrm{n}_{\mathrm{T},(\mathrm{K}+1)}}\right)\right\}
$$

Solving yields

$$
\frac{\mathrm{n}_{\mathrm{H} 2,(\mathrm{~K}-1)}}{\mathrm{n}_{\mathrm{T},(\mathrm{K}-1)}}=\frac{\mathrm{n}_{\mathrm{H} 2, \mathrm{~K}}}{\mathrm{n}_{\mathrm{T}, \mathrm{K}}}+\left\{\left(\frac{\mathrm{L}_{\mathrm{R}, \mathrm{K} \rightarrow(\mathrm{K}+1)}}{\mathrm{L}_{\mathrm{R},(\mathrm{K}-1) \rightarrow \mathrm{K}}}\right)\left(\frac{\mathrm{n}_{\mathrm{H} 2, \mathrm{~K}}}{\mathrm{n}_{\mathrm{T}, \mathrm{K}}}-\frac{\mathrm{n}_{\mathrm{H} 2, \mathrm{~K}+1}}{\mathrm{n}_{\mathrm{T}, \mathrm{K}+1}}\right)\right\}
$$




\section{CHPRC-01674, Rev. 1}

To solve the above equations, the hydrogen generation rate and the hydrogen gas transport rate $\mathrm{L}_{\mathrm{R},(\mathrm{K}-1) \rightarrow \mathrm{K}}$ are needed. These parameters are found in the next three sections. 
CHPRC-01674, Rev. 1

This page is intentionally left blank. 


\subsection{Hydrogen Generation Rate}

To solve the diffusion equations developed in Section 2.0, the hydrogen generation rate is needed. This parameter is found within this section.

The hydrogen generation rate is found from the energy released during the decay and the ability of the material to release the hydrogen from the molecular structure as a result of the absorption of the released energy. The energy released is a function of the curies contained in the inventory, and the energy released applies to each disintegration. The hydrogen release is obtained from an experimentally derived parameter called the " $\mathrm{G}$ value" or $\mathrm{G}\left(\mathrm{H}_{2}\right)$. The units are "molecules of hydrogen per 100 ev absorbed."

The equation for hydrogen generation is:

$$
\mathrm{n}_{\mathrm{H} 2 \text {,gen }}=\frac{(\# \text { of } \mathrm{Ci}) *\left(3.7 \times 10^{10} \frac{\mathrm{dis}}{\mathrm{s}-\mathrm{Ci}}\right) *\left(\text { energy released, } \frac{\mathrm{ev}}{\mathrm{dis}}\right) *\left[\mathrm{G}\left(\mathrm{H}_{2}\right), \frac{\text { molecules } \mathrm{H}_{2}}{100 \mathrm{ev}}\right]}{\left(6.02 \mathrm{E}+23 \frac{\text { molecules }}{\mathrm{mole}}\right)} \text { moles } / \mathrm{s}
$$

Note in the equation above, the value of $\left[\mathrm{G}\left(\mathrm{H}_{2}\right), \frac{\text { molecules } \mathrm{H}_{2}}{100 \mathrm{ev}}\right]$ is found by dividing the value of $\mathrm{G}\left(\mathrm{H}_{2}\right)$ by 100 . For example, Section 3.2 will show that $\mathrm{G}\left(\mathrm{H}_{2}\right)$ equals 1.6 molecules per $100 \mathrm{ev}$. Given this, the term $\left[\mathrm{G}\left(\mathrm{H}_{2}\right), \frac{\text { molecules } \mathrm{H}_{2}}{100 \mathrm{ev}}\right]$ equals $1.6 / 100$ or 0.016 .

\subsection{Number of Curies and Energy Released}

The term "\# of Ci" in the equation for hydrogen generation rate is the number of curies of alpha emitting isotopes in the package. While gamma and betas also produce hydrogen, for the portions of waste packages containing TRU isotopes (i.e., plutonium and americium), only the contribution from the alphas need to be included as the contribution from the betas and gammas is negligible. .

The equation for the hydrogen generation requires the number of curies and the average energy released for disintegration. For the packages of interest in this analysis, these parameters are found from the "worst-case" plutonium in the PFP DSA (HNF-15500,). This isotopic distribution is taken from Table 4-2, Section 4.2.3 of Revision 8 to HNF-15500. It is known as the " $>10 \% \mathrm{Pu}-240$ distribution." This is a mass weighted average of the results of several thousand non-destructive sample analyses from eight and one-half years of PFP inventory records. This isotopic distribution conservatively includes a maximum ${ }^{241} \mathrm{Am}$ buildup. The isotopic distribution is shown in the second column in Table 3-2, Calculation of the Average Energy per Disintegration.

The specific activity (curies/gram) came from rounding the values found in RADIDOSE (HNF-26181, User's Guide and Model Description for RADIDOSE Version 3.0). RADIDOSE is the code used to determine the onsite and offsite consequences for the DSA performed for the Hanford facilities. The values from RADIDOSE were compared to LA-12846-MS, Specific Activities, and DOE-STD-1027-92, Hazard Category 2 Thresholds - LANL Fact Sheet, which is 
used by the DOE for Hazard Categorization and HNF-EP-0063, 2011, Hanford Site Solid Waste Acceptance Criteria, the document used at Hanford to determine if the waste is acceptable.

The information presented in Table 3-1, Search Results for Specific Activity, below shows that, with the exception of the specific activity of ${ }^{239} \mathrm{Pu}$ in LA-12846, the values from the three references are very close to the value used in this analysis. A search of the Internet was done to check the specific activity of ${ }^{239} \mathrm{Pu}$ used in the analysis $(0.062 \mathrm{Ci} / \mathrm{g})$. The specific activity of ${ }^{239} \mathrm{Pu}$ found that from a number of authoritative references (including a 2003 Los Alamos DSA for the waste tanks located at TA-21 given in LA-UR-03-6520, the General's Tanks Characterization Activities Documented Safety Analysis) and a later version of the radionuclide decay charts, all show a specific activity of ${ }^{239} \mathrm{Pu}$ of $0.062 \mathrm{Ci} / \mathrm{g}$. The search results show that the use of a specific activity of ${ }^{239} \mathrm{Pu}$ of $0.062 \mathrm{Ci} / \mathrm{g}$ is a good choice.

Table 3-1. Search Results for Specific Activity

\begin{tabular}{|l|c|c|c|}
\hline & $\begin{array}{c}\text { Specific activity, } \\
\text { Ci/g used in this } \\
\text { analysis } \\
\text { (From RADIDOSE, } \\
\text { HNF-26181) }\end{array}$ & $\begin{array}{c}\text { Specific Activity, } \\
\text { Ci/g used in } \\
\text { LA-12846-MS, } \\
\text { Table 1 }\end{array}$ & $\begin{array}{c}\text { Specific Activity, } \\
\text { Ci/g used in } \\
\text { HNF EP-0063, } \\
\text { Table A-1 }\end{array}$ \\
\hline${ }^{238} \mathrm{Pu}$ & 17.1 & 17.13 & 17.12 \\
\hline${ }^{239} \mathrm{Pu}$ & 0.062 & 0.06133 & 0.06202 \\
\hline${ }^{240} \mathrm{Pu}$ & 0.23 & 0.2268 & 0.2269 \\
\hline${ }^{241} \mathrm{Pu}$ & 100 & 103.1 & 103 \\
\hline${ }^{242} \mathrm{Pu}$ & 0.004 & 0.00393 & 0.003954 \\
\hline${ }^{241} \mathrm{Am}$ & 3.43 & 3.428 & 3.427 \\
\hline
\end{tabular}

Notes:

HNF-26181, User's Guide and Model Description for RADIDOSE

Version 3.0, Fluor Hanford, Inc., Richland, Washington.

LA-12846-MS, Specific Activities and DOE-STD-1027-92 Hazard Category 2 Thresholds - LANL Fact Sheet, Los Alamos National Laboratory, Los Alamos New Mexico. This reference refers to the Seventh edition (1978) of the Table of Isotopes.

HNF-EP-0063, Hanford Site Solid Waste Acceptance Criteria, Rev 16, CH2M HILL Plateau Remediation Company, Richland, Washington.

Table 3-2, Calculation of the Average Energy per Disintegration, presents the calculation of the curies in the drum and the average energy. The data on energy per disintegration was taken from the Radiological Health Handbook.

In calculations such as these, the contribution from ${ }^{241} \mathrm{Pu}$ and the gamma from ${ }^{241} \mathrm{Am}$ are neglected. This is because the energy given off by ${ }^{241} \mathrm{Pu}$ is a weak beta (energy $=0.021 \mathrm{Mev}$, max and $0.007 \mathrm{Mev}$ average [using the fact that the average beta energy is about one-third of the maximum energy]). The maximum energy given off from the gamma emission from ${ }^{241} \mathrm{Am}$ is $0.06 \mathrm{Mev} 36$ percent of the time (See Note 1 of Table 3-2). The hydrogen generation rate is a 
function of the curies present and the energy per disintegration. The last column in Table 3-2 shows the contribution of ${ }^{241} \mathrm{Pu}$ beta and the ${ }^{241} \mathrm{Am}$ gamma to the generation rate is about 1 percent. This shows that the contribution of the gammas is negligible. This is confirmed by Section 3.1 of the $\mathrm{CH}$-TRU Payload Appendices, which states: "For the CH-TRU wastes, alpha irradiation is the only significant contributor to gas generation." 
Table 3-2. Calculation of the Average Energy per Disintegration

\begin{tabular}{|c|c|c|c|c|c|}
\hline & $\begin{array}{c}\text { Normalized mass } \\
\text { fraction } \\
\left(>10 \%{ }^{240} \mathrm{Pu}\right. \\
\text { isotopic } \\
\text { distribution) }\end{array}$ & $\begin{array}{c}\text { Specific } \\
\text { activity, } \mathrm{Ci} / \mathrm{g}\end{array}$ & Curies & Mev/dis & $\mathrm{Ci}^{*}(\mathrm{Mev} / \mathrm{dis})$ \\
\hline${ }^{238} \mathrm{Pu}$ & 0.00205 & 17.1 & 0.0351 & $\begin{array}{l}5.49 \\
\text { (from } 5.50,72 \% \text { of the } \\
\text { time and } 5.46,28 \% \text { of the } \\
\text { time) }\end{array}$ & 0.192 \\
\hline${ }^{239} \mathrm{Pu}$ & 0.794 & 0.062 & 0.0492 & $\begin{array}{l}5.15 \\
\text { (from } 5.16,88 \% \text { of the } \\
\text { time and } 5.11,12 \% \text { of the } \\
\text { time) }\end{array}$ & 0.253 \\
\hline${ }^{240} \mathrm{Pu}$ & 0.159 & 0.23 & 0.0366 & $\begin{array}{l}5.16 \\
\text { (from } 5.17,76 \% \text { of the } \\
\text { time and } 5.12,24 \% \text { of the } \\
\text { time) }\end{array}$ & 0.189 \\
\hline${ }^{241} \mathrm{Pu}$ & 0.0137 & 100 & 1.37 & 0.007 (beta) & 0.01 \\
\hline${ }^{242} \mathrm{Pu}$ & 0.00654 & 0.004 & $2.6 \mathrm{E}-5$ & 4.9 & $\sim 0$ \\
\hline${ }^{241} \mathrm{Am}$ & 0.0241 & 3.43 & 0.0827 & $\begin{array}{l}5.48 \text { (alpha) } \\
\text { (from } 5.49,85 \% \text { of the } \\
\text { time and } 5.44,13 \% \text { of the } \\
\text { time) } \\
0.06 \text { (gamma) } \\
\text { (36\% of the time - } \\
\text { See Note } 1 \text { ) }\end{array}$ & 0.002 \\
\hline Totals & 1.0 & & $\begin{array}{l}0.2035 \\
\text { (does not } \\
\text { include Pu- } \\
241)\end{array}$ & & $\begin{array}{l}1.1 \\
\text { (Notes 1,2) } \\
\text { Average alpha } \\
\text { energy } \\
5.34 \mathrm{Mev} / \mathrm{dis}\end{array}$ \\
\hline
\end{tabular}

Notes:

The Average alpha energy $=\frac{\sum C i_{i} * M e v_{i}}{\sum C i_{i}}$, not including Pu-241. Using this, the average alpha energy is 5.34 Mev/dis.

Am-241 decays to Np-237 via alpha emission. Most of the time, the alpha emission leads to a ground state Np-237 atom. About half of the time, alpha emission leads to an excited Np-237 atom, which decays to the ground state by gamma emission, $36 \%$ of the time the gamma emission is $0.06 \mathrm{Mev}$ and $14 \%$ of the time it decays via much lower gamma energies. There are greater gamma energies given off, but the frequency is many orders of magnitude smaller than $36 \%$. 
The average energy per gram is found from:

$$
\frac{0.2036 \mathrm{Ci}}{g} * \frac{3.7 E 10 \mathrm{dis}}{\mathrm{s}-\mathrm{Ci}} * \frac{5.34 \mathrm{Mev}}{\mathrm{dis}} * \frac{1 E 6 \mathrm{ev}}{\mathrm{Mev}} * \frac{1.6 E-19 \mathrm{~J}}{e v} * \frac{1 \mathrm{~W}}{\mathrm{~J} / \mathrm{s}}=\frac{0.0064 \mathrm{~W}}{\mathrm{~g}}
$$

The inventory is assumed to be located such that all of the released alpha energy is absorbed by the hydrogenous material. It is assumed that these radionuclides are absorbed in or encased in the hydrogenous material.

\subsection{Determination of $\mathbf{G}\left(\mathbf{H}_{2}\right)$}

The effective radiolytic hydrogen $G$ value is a measure of the number of hydrogen molecules generated through radiolysis per $100 \mathrm{ev}$ of ionizing energy deposited into a waste matrix. The value is both waste type and time dependent. Generally, the more hydrogenous material available, the higher the $G$ number, and as the absorbed dose increases, the G value may decrease to an approximate steady state condition. Increasing the dose (defined as the product of the decay heat and elapsed time from waste generation to date of compliance evaluation and expressed in units of watt*year) decreases the flammable gas generation rate of the hydrogenous materials (such as plastics and combustibles) due to the depletion of the hydrogen in the target material in the vicinity of the alpha-emitting sources. Both $\mathrm{G}$ values and the matrix-depletion criterion of $>0.012$ watt*year per container are provided in Section 3.2, Table 3.2-1 of the $\mathrm{CH}$ TRU Payload Appendices, which summarizes the effective G values at an assumed room temperature of $70{ }^{\circ} \mathrm{F}$. A summary of this information is provided in Table 3-3, Summary of $G$ Values for alpha-emitting radionuclides from CH-TRU Payload Appendices. The values are based on alpha radiation.

Table 3-3. Summary of G Values for alpha-emitting radionuclides from $C H$-TRU Payload Appendices

\begin{tabular}{|l|l|}
\hline \multicolumn{1}{|c|}{ Waste Material Type } & \multicolumn{1}{|c|}{$\begin{array}{c}\text { Effective G Values - } \\
\text { Flammable Gas, i.e., } \\
\text { G(H } \mathbf{H}_{2} \text { ) }\end{array}$} \\
\hline \begin{tabular}{l} 
I. Solidified aqueous or homogeneous inorganic solids (that contain water) \\
\hline $\begin{array}{l}\text { I.1 Absorbed, adsorbed, or solidified inorganic liquids (nuclides may be in solution } \\
\text { and energy transfer may occur between the liquid and the inorganic binder). }\end{array}$
\end{tabular} & 1.6 \\
\hline I.2 Soils, solidified particulates, or sludge formed from precipitates. & 1.3 \\
\hline $\begin{array}{l}\text { I.3 Concreted inorganic particulate waste having a maximum of 30 weight percent } \\
\text { unbound water. }\end{array}$ & 0.4 \\
\hline II. Solid inorganic materials & $\begin{array}{l}1.7 \text { (watt*year } \leq 0.012) \\
0.32(\text { watt*year }>0.012)\end{array}$ \\
\hline \begin{tabular}{l} 
II.1 Solid inorganic materials packaged in organic materials. \\
\hline
\end{tabular}
\end{tabular}


Table 3-3. Summary of G Values for alpha-emitting radionuclides from $C H$-TRU Payload Appendices

\begin{tabular}{|c|c|}
\hline Waste Material Type & $\begin{array}{l}\text { Effective G Values - } \\
\text { Flammable Gas, i.e., } \\
\qquad \mathbf{G}\left(\mathbf{H}_{2}\right)\end{array}$ \\
\hline II.2 Solid inorganic materials packaged in metal cans. & 0 \\
\hline $\begin{array}{l}\text { II. } 3 \text { Homogeneous solid inorganic materials with unbound absorbed ambient moisture } \\
\text { ( } \leq 6 \% \text { by weight) in metal cans. }\end{array}$ & 0.08 \\
\hline \multicolumn{2}{|l|}{ III. Solid organic materials } \\
\hline III.1 Solid organic materials (including some absorbed liquids and cemented organics). & $\begin{array}{l}3.4(\text { watt*year } \leq 0.012) \\
1.09(\text { watt*year }>0.012)\end{array}$ \\
\hline $\begin{array}{l}\text { III. } 2 \text { Homogeneous mixed organic ( } 10 \% \text { by weight) and inorganic ( } 90 \% \text { by weight) } \\
\text { materials packaged in metal cans. }\end{array}$ & $\begin{array}{l}0.34(\text { watt* } * \text { year } \leq 0.012) \\
0.11 \text { (watt*year }>0.012)\end{array}$ \\
\hline $\begin{array}{l}\text { III. } 3 \text { Homogeneous mixed organic ( } 10 \% \text { by weight) and inorganic ( } 90 \% \text { by weight) } \\
\text { materials packaged in organic materials. }\end{array}$ & $\begin{array}{l}1.85(\text { watt*year } \leq 0.012) \\
0.4(\text { watt*year }>0.012)\end{array}$ \\
\hline
\end{tabular}

Given the high decay heat of the maximum PFP drum (1.6 watts based on $250 \mathrm{~g}$ of the " $>10 \%$ $\mathrm{Pu}-240$ " mixture), it is apparent that the matrix depletion criteria will be met in a short time (under three days). Section 6.2 shows a PTO may have about $50 \mathrm{~g}$ of Plutonium in it. For this package, the heat rate is $0.32 \mathrm{~W}$. The matrix-depletion value of $\mathrm{G}\left(\mathrm{H}_{2}\right)$ can be used after about two weeks (14 days).

For this analysis, two $\mathrm{G}$ values are selected for evaluation from Table 3-3. The first is 0.4 molecules per $100 \mathrm{ev}$ which bounds the highest wattage inorganic (Type II) and solid organic waste materials (Type III.2 and III.3). The second is 1.6 molecules per $100 \mathrm{ev}$ which bounds the solidified aqueous or homogeneous inorganic solids (Type I) and high wattage solid organic materials with absorbed liquids (Type III.1).

\subsection{Hydrogen Generation Rate}

Substituting the values for "\# of $\mathrm{Ci}$," average energy per disintegration and $\mathrm{G}\left(\mathrm{H}_{2}\right)$ for an inventory of $250 \mathrm{~g}$ of plutonium having a radionuclide distribution equal to the rate in the PFP DSA (" $>10 \% \mathrm{Pu}-240 ")$ yields the hydrogen generation rate. For $250 \mathrm{~g}$ of plutonium having the isotopic distribution given in Table 3-3, Summary of G Values for alpha-emitting radionuclides from CH-TRU Payload Appendices, the number of curies and energy released are:

$$
\begin{aligned}
\# \text { of } \mathrm{Ci} & =250 \mathrm{~g} * 0.2035 \mathrm{Ci} / \mathrm{g} \\
& =50.9 \mathrm{Ci} \\
\text { Energy released } & =5.34 \mathrm{Mev} / \mathrm{dis} \\
& =5.34 \times 10^{6} \mathrm{ev} / \mathrm{dis}
\end{aligned}
$$


Substituting these two values and the two values of $\mathrm{G}\left(\mathrm{H}_{2}\right)$ of interest $(1.6$ molecules /100 ev and 0.4 molecules $/ 100 \mathrm{ev}$ ) into the equation for the hydrogen generation rate presented in Section 3.0,

$$
\mathrm{n}_{\mathrm{H} 2, \text { gen }}=\frac{(\# \text { of Ci }) *\left(3.7 \times 10^{10} \frac{\mathrm{dis}}{\mathrm{s}-\mathrm{Ci}}\right) *\left(\text { Energy released, } \frac{\mathrm{ev}}{\mathrm{dis}}\right) *\left[\mathrm{G}\left(\mathrm{H}_{2}\right), \frac{\text { molecules } \mathrm{H}_{2}}{100 \mathrm{ev}}\right]}{\left(6.02 \mathrm{E}+23 \frac{\text { molecules }}{\text { mole }}\right)}
$$

yields:

$6.7 \times 10^{-8} \mathrm{~mole} / \mathrm{s}$ for a value of $\mathrm{G}\left(\mathrm{H}_{2}\right)$ of 0.4 and an inventory of $250 \mathrm{~g}$ of " $>10 \% \mathrm{Pu}-240$ " plutonium mixture,

$2.7 \times 10^{-7} \mathrm{~mole} / \mathrm{s}$ for a value of $\mathrm{G}\left(\mathrm{H}_{2}\right)$ of 1.6 and an inventory of $250 \mathrm{~g}$ of " $>10 \% \mathrm{Pu}-240$ " plutonium mixture.

The hydrogen generation rate for the analysis shown in Section 6 is calculated in the same way, using the specified inventory in the waste package. 
CHPRC-01674, Rev. 1

This page is intentionally left blank. 


\subsection{Permeability}

To solve the diffusion equations developed in Section 2.0, the hydrogen gas transport rate $\mathrm{L}_{\mathrm{R},(\mathrm{K}-1) \rightarrow \mathrm{K}}$ is needed. This parameter is broken into two parts; permeability of the surface of the portion of the plastic waste package and diffusion through closure (i.e., "horse-tail"). The permeability of the surface is found in this section.

The hydrogen transport rate $\left(\mathrm{L}_{\mathrm{R}, \mathrm{i} \rightarrow \mathrm{j}}\right)$ includes hydrogen transport through the bag walls (permeation), through a filter or opening in the portion of the waste package (filter on a drum or open bung hole in the liner).

Permeation (hydrogen diffusion through solid layer of plastic) is discussed in this section. Section 5.0 will discuss diffusion through "twist and tape" closures. Diffusion through open airfilled pathways is discussed in Section 6.0.

For plastic bags that are the same size as those used in WIPP testing, the values developed by the WIPP tests are used in the analysis.

The permeability values are used for those plastic bags (or plastic waste containers), which are of a different size or material than those analyzed or tested by WIPP. A search of the Internet was done to find the values of permeability of polyvinyl chloride (PVC) and other plastics. The results of the search are shown in Appendix B, Literature Search for Values for Permeability of Plastics. In each section of Appendix B, the paper or journal article is cited, followed by the value for the permeability.

The permeability value used in the analysis (Section 6.0) comes from the tests performed at WIPP. Appendix B shows the permeability value derived from the WIPP test. The permeability value is the value that WIPP used to determine the allowable inventory for the TRUCON Code requirements, and therefore is a reasonable value to use.

Table 6.8-5 of Section 6.8 of Rev. 1 (Rev. 2 is the latest) of CH-TRU Payload Appendices provides the permeability of a PVC bag of $4.94 \mathrm{E}-7$ moles/s-mole-fraction based on a heat sealed 14-mil thick PVC bag having a surface area of $6.3 \mathrm{ft}^{2}$ (per Table 6.8-1 of the reference). Table $6.8-1$ shows that the test was performed at $50^{\circ} \mathrm{F}$. It is assumed that the temperature in the waste packages and container are $77^{\circ} \mathrm{F}$. The value, obtained by WIPP at $50^{\circ} \mathrm{F}$ is used in this analysis based on their response to our questions concerning what diffusivity to use (See Question 2, Appendix G). Their response stated that they used the diffusivity from the test for their analysis of the TRUCON code for this waste package. Based on the response, the diffusivity from the test is used in this analysis.

Using the following conversion factors:

At $25{ }^{\circ} \mathrm{C}(298 \mathrm{~K}), 1$ moles occupies $24,450 \mathrm{~cm}^{3}$

$14-\mathrm{mil}=0.014$ in or $0.0356 \mathrm{~cm}$

$6.3 \mathrm{ft}^{2}=5,861 \mathrm{~cm}^{2}$

1 mole frac $=76 \mathrm{cmHg}$ (see paragraph 1 of Appendix B). 
The permeability of the PVC bag is:

$$
\begin{aligned}
& \frac{4.94 E-7 \text { moles }}{s-\text { mole frac. }} * \frac{24,450 \mathrm{~cm}^{3}}{\text { mole }} * \frac{0.0356 \mathrm{~cm}}{5861 \mathrm{~cm}^{2}} * \frac{\text { mole frac. }}{76 \mathrm{cmHg}}= \\
& 9.6 \mathrm{E}-10 \frac{\mathrm{cm}^{3}}{\mathrm{~s}} \frac{\mathrm{cm}}{\mathrm{cm}^{2}-\mathrm{cmHg}} \\
& \left(\text { Rounded to } 10 \mathrm{E}-10 \text { or } 1 \mathrm{E}-9 \frac{\mathrm{cm}^{3}}{\mathrm{~s}} \frac{\mathrm{cm}}{\mathrm{cm}^{2}-\mathrm{cmHg}}\right)
\end{aligned}
$$

Where the bag used in the waste package is the same size as this bag (surface area of $\left[5,861 \mathrm{~cm}^{2}\right]$ $6.3 \mathrm{ft}^{2}$ ), a value of $4.94 \times 10^{-7} \mathrm{moles} / \mathrm{s}-\mathrm{mole}$ fraction is used.

For the cases where the bag is a PVC bag having a different thickness or surface area, the permeability of $1 \times 10^{-9} \mathrm{~cm}^{3}-\mathrm{cm} / \mathrm{s}-\mathrm{cm}^{2}-\mathrm{cmHg}$ is used. Appendix B shows the permeability of $1 \times 10^{-9} \mathrm{~cm}^{3}-\mathrm{cm} / \mathrm{s}-\mathrm{cm}^{2}-\mathrm{cmHg}$ is a reasonable value. 


\subsection{Permeability of "Horse-Tailed" or "Twist And Wrap" Closures}

To solve the diffusion equations developed in Section 2.0, the hydrogen gas transport rate $\mathrm{L}_{\mathrm{R},(\mathrm{K}-1) \rightarrow \mathrm{K}}$ is needed. This parameter is broken into two parts: permeability of the surface of the portion of the plastic waste package and diffusion through the closure (i.e., "horse-tail"). The diffusivity of the closure is found in this section.

Bags can be closed by twisting and taping the opening (i.e., "horse-tail"). Other closure mechanisms are discussed at the end of this section. For these bags, there is hydrogen transport out of the surface of the bag and out of the opening in the core of the twist. Some twist and tape closures involve folding the twisted portion prior to taping.

The diffusivity for the twist and tape closure is found using the data from the test at WIPP. Appendix C, A Literature Search for Values for Permeability of the Diffusivity of Twist and Tape Closures on Plastic Bags, provides the WIPP test data as well as data from two other tests performed at other locations. In each of these tests (described in Appendix C), the method for "twist and tape" (i.e., "horse-tailing") is described as follows:

Securely twist a portion of the bag. Wrap tape around the twisted end. Cut the tape at the midpoint of the taped length. Add a layer of tape to seal off the "open" end (i.e., the end that was just cut).

This is the same method used at PFP, based on Procedure ZSP-003, Page 8 of 15, Seal Out from Glovebox or Glovebag or Remove Items from Hoods, and as taught in Section 3.3.6 of Chapter 3 entitled "Glovebox Work" of the PFP Student Handbook for Nuclear Chemical Operators for Course 200135.

Section 6.8.7.2.2 of Rev. 1 (Rev 2. is the latest) of CH-TRU Payload Appendices, states the diffusivity of the twist-and-taped section (the "horse-tail"), alone, is $5.6 \mathrm{E}-7$ moles/s-molefraction. The reference states that the value was obtained by subtracting the diffusivity of Test 9A from Test 9C. In each case, a 14-mil thick PVC bag having a surface area of 5,861 $\mathrm{cm}^{2}(6.3$ $\mathrm{ft}^{2}$ ) (per Table 6.8-1) was used in the test.

The length of the twist and tape portion is approximated as follows. The initial bag dimension is 10 by $72 \mathrm{in.} \mathrm{The} \mathrm{surface} \mathrm{area} \mathrm{of} \mathrm{the} \mathrm{finished} \mathrm{bag} \mathrm{is} 6.3 \mathrm{ft}^{2}$. Assume the bag is essentially flat (that is the configuration in the tests shown in Section 6.8 of CH-TRU Payload Appendices). Given a width of $10 \mathrm{in}$, the length of the bag to yield a surface area of $6.3 \mathrm{ft}^{2}$ is $45 \mathrm{in}$. This means that the initially twisted length is about 27 in. Assuming the twisted portion is cut in half, the twist and tape length is about 13 in.

Sketches of the Bag around the sonotube show the actual bag is $103 \mathrm{in.} \mathrm{long.} \mathrm{The} \mathrm{lower} \mathrm{portion}$ of the bag is $15 \mathrm{in.}$ in diameter and $52 \mathrm{in.} \mathrm{long.} \mathrm{The} \mathrm{diameter} \mathrm{then} \mathrm{increases} \mathrm{to} 20 \mathrm{in}$. over a length of $21 \mathrm{in}$. The bag is $20 \mathrm{in}$. in diameter over the last $30 \mathrm{in}$. The sonotube is placed into the 15-in. diameter by 52-in. long bag. The upper portion is used in the twist and tape portion. The PTO is 45 in. long. The twisted length is about 51 in. long (from 103 in. minus 52 in.). The length is twisted, taped, and cut so it will fit into the PTO. As a result, the twist and tape portion of the bag around the sonotube is about the same size as those used in the WIPP tests. Therefore, the WIPP test value for the twist and tape closure (5.6 E-7 moles/s-mole-fraction) could be used in the analysis. Additional justification is shown in Section 6.2.2. 


\section{CHPRC-01674, Rev. 1}

Waste packages can be closed by heat sealing the top and installing a filter. In this case, the diffusivity is provided by the manufacturer for that particular filter. 


\subsection{Results Using the Spreadsheet}

In the sections to follow, terms having units of " $\mathrm{cm}^{3}-\mathrm{cm} / \mathrm{s}-\mathrm{cm}^{2}-\mathrm{cmHg}$ " are called permeability. Terms having units of "moles/s-mole fraction" are called diffusivity. This is in keeping with the term "diffusivity" used by Nuclear Filter Technology for their filters (See Appendix A of HNF16166, Required Staging Times for Hydrogen Diffusion in Vented Waste Containers).

\subsection{The 6-Bag Spreadsheet Used For the TRUCON Codes}

A spreadsheet was developed to solve the six-bag equations, the liner equation, and the drum equation. The results from this spreadsheet were used to compare the hydrogen concentration in the inner bag for the TRUCON Codes, RH 125/225. The results are provided in Appendix E, "Sensitivity Analysis Performed with 6-Bag Spreadsheet Modeling the TRUCON Code Configurations." The spreadsheet used is similar to the one shown in Appendix H. The only difference is the spreadsheet contains eight volumes (or "bags), whereas the one in Appendix E contains five.

The six bags were all assumed to have a thickness of 14-mils. The permeability was chosen so the diffusivity matched the data in Appendix D, "E-Mail from Murthy Devarakonda, WIPP, Giving the Diffusivities Used by WIPP."

The results in Appendix E show that for each condition of the TRUCON Code studied, the spreadsheet described in Section 2.0 and Appendix A shows the hydrogen concentration is below 5 percent. As a result, the spreadsheet described in Section 2.0, Appendix A and Appendix H, is a reasonable method to determine the hydrogen in the innermost portion of the waste package as the results generally match those obtained by WIPP in the development of the allowable inventory for the TRUCON Code.

\subsection{Hydrogen Diffusions in the PTO/SWB Waste Package}

The equations described in Section 2.0 were coded into a spreadsheet using the method of Appendix A. The spreadsheet is shown in Appendix H. The spreadsheet was developed to include a liner for those cases where a liner might be used in the future. In the cases where no liner is used, the diffusivity of the "Liner" is set equal to 1.0.

\subsubsection{Dimensions, Diffusivities and Initial Conditions of the PTO/SWB Waste Package}

Pencil tank assemblies are removed from their wall-mounted location within the Plutonium Reclamation Facility (PRF) Canyon, moved to the maintenance cell, and mounted on the wall. The plutonium mass is then determined. Liquids and packing material (e.g., raschig rings), if present within the pencil tank assemblies, is removed. The pencil tanks are then size reduced (i.e., cut into smaller lengths). Sections of the pencil tanks are placed inside an open top Miscellaneous Material Container (MMC). MMCs may also be used to contain the packing material.

The MMCs, with the pencil tank sections, are moved from the maintenance cell to the PRF Mezzanine. 
The MMCs are sealed out of the canyon into a PTO Assembly. The PTO will have a contamination control liner inside. The liner is a PVC bag called a sonotube bag. The sonotube bag will contain a rigid liner (the sonotube). Prior to placement in the PTO, a wood plug is placed within the bottom of the sonotube and nailed in place.

The MMC is placed into the sonotube. A 2-in. thick spacer cushion is placed on top of the MMC within the sonotube. After the spacer cushion has been placed, the PVC bag is closed around the sonotube with the MMC and spacer cushion, using a twist and tape (also called "horse-tail") closure. The remaining end cap is then taped on. (See Figure 6-1, "PTO Loading Diagram")

The loaded PTO is then packed into an SWB. Up to two layers of three PTO assemblies per layer can be placed in an SWB. The layer of three PTO assemblies consist of two short PTOs and one long PTO. The total plutonium inventory allowed within the SWB is $325 \mathrm{~g}$. For purposes of this analysis, all of the PTOs are assumed to be short PTOs. This is conservative in that the long PTOs have larger surface areas for diffusion to occur.

The components of the PTO are shown in Figure 6-1. 


\section{PRF Pencil Tank Disposal Package}

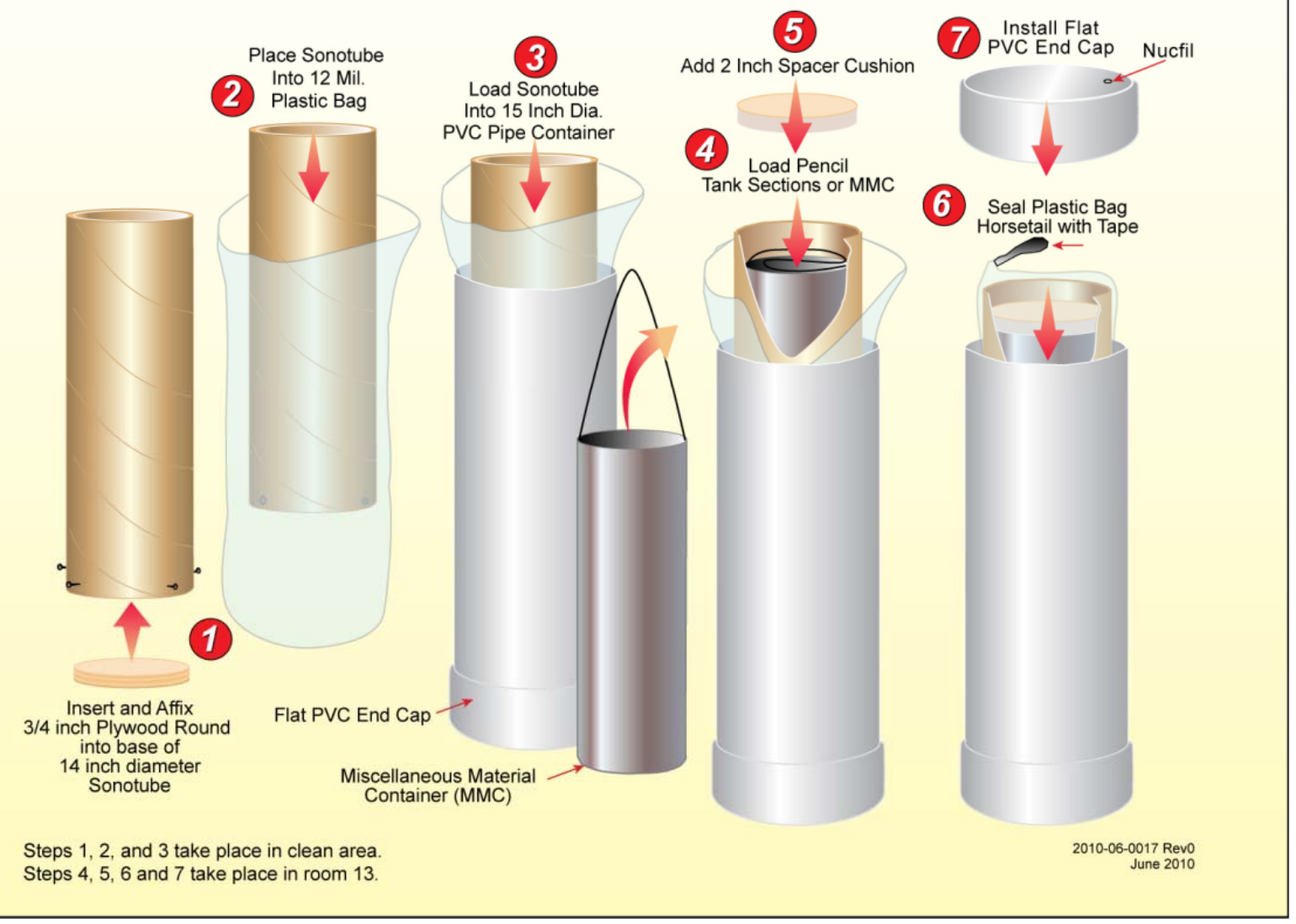

Figure 6-1. PTO Loading Diagram

A facility drawing (H-2-836485, Pencil Tank Overpack Assemblies) has been recently issued. The drawing shows the assembly, the dimensions of the pieces, and the materials of construction. The components of the PTO are:

- $\mathrm{MMC}-\mathrm{The} \mathrm{MMC}$ is made of steel. It is $13 \mathrm{in}$. in diameter and $39 \mathrm{in.} \mathrm{long} \mathrm{(See} \mathrm{Work}$ Package 2Z-10-0184 - MMC Drawing). MMC has an open top and a screen as the base. There are four 1-inch diameter holes in the base of the MMC. The centers of the holes are located two inches above the base of the MMC.

- Sonotube - The sonotube is a 14-in. diameter cardboard-like container. Sonotubes are used as concrete forms. The sonotube for the short PTO is $44 \mathrm{in.} \mathrm{long.} \mathrm{The} \mathrm{sonotube} \mathrm{for}$ the long PTO is about 61 in. long (Dimensions are per 2Z-10-0184-045-00 [Work Package 2Z-10-0184 - Sonotube and PTO]). The walls are 0.25-in. thick. The base of the sonotube is a wood plug. The plug is about 0.75 -in. thick. The sonotube is nailed to the plug. The dimensions are also shown in Drawing H-2-836485, Pencil Tank Overpack Assemblies. Some sonotubes contain four 0.50 -in. diameter holes drilled into the sonotube wall. The holes are located about three inches from the base. Those that do not 
contain the 0.5 -inch diameter holes in the sonotube wall, contain a 2.25 -in. diameter hole in the sonotube cushion.

- Sonotube cushion - A spacer cushion (also called the sonotube cushion) is inserted into the sonotube. The 2-in. thick spacer cushion is made of AP/ARMAFLEX ${ }^{\circledR 1}$ pipe insulation, a closed cell elastomeric foam. The dimensions and materials are also shown in Drawing H-2-836485, Pencil Tank Overpack Assemblies. Most of the sonotube cushions contain a 2.25-in. diameter hole.

- Sonotube Bag - The contamination control liner (also called sonotube bag) is a 12-mil PVC bag. The bag diameter and height are discussed in Section 6.2.2, below.

- PTO - The PTO is a 15-in. diameter, Schedule 40 PVC pipe. End caps are glued on the bottom and taped on the top. The short PTO is 15 in. in diameter and 43 in. long. The long PTO is 60 in. long (Dimensions are per 2Z-10-0184-045-00[Work Package 2Z-100184 - Sonotube and PTO]). The PTO has a NucFil-013 filter in the top end-cap. The normal configuration is four short PTOs and two long PTOs) placed within an SWB. However, in this analysis, only the short sonotubes are used as the results are conservative. The dimensions are also in Drawing H-2-836485, Pencil Tank Overpack Assemblies.

The PTOs are placed into a SWB. The SWB dimensions are provided in WIPP drawing 165-F001-W1, Standard Waste Box Assembly. The SWB is 36 in. tall. It has an inside width of 52 in. and curved ends. The inside length varies from 45-69 in. long. The SWB contains two NucFil019DS filters.

Other assumptions used in the analysis are:

- Unless it is specifically noted, it is assumed the hydrogen generation rate is determined using the largest value for $\mathrm{G}\left(\mathrm{H}_{2}\right)$ shown in Section 3.3 assuming that the matrix depletion criterion is used. The value of $\mathrm{G}\left(\mathrm{H}_{2}\right)$ used in the analysis is 1.6, to be conservative. Matrix depleted values for all those materials that undergo matrix depletion are less than this value.

- The maximum allowable hydrogen concentration in the sonotube is 5 percent, per WIPP (See Response to Question 3 in Appendix G, "Clarification of Data Used by WIPP in the Development of the TRUCON Code for PTO in SWB"). The analysis used 4.8\% hydrogen to be conservative.

- Plutonium values used in the analysis are best estimate values from the NDA. Best estimate values are used as they are most representative of the inventory that is generating hydrogen.

\footnotetext{
${ }^{1}$ ARMAFLEX is a registered trademark of Armstrong Cork Company Corporation Pennsylvania Liberty and Charlotte STS, Lancaster, Pennsylvania. The material AP/Armaflex or Armacell is a special form of Armaflex.
} 


\subsubsection{Hydrogen Concentration in the Sonotube of SWBs Previously Shipped}

Forty SWBs were packaged with PTOs and shipped to the Central Waste Complex (a separate facility not part of PFP.

Table 6-2 shows the isotopic distribution for the 40 SWBs that have been shipped as well as the inventory for some of the higher mass SWBs. The data comes from the NDA. The forty SWBs that have been shipped contain about half of the pencil tanks that have to be removed. As a result, the isotopic distribution is believed to be representative of the remainder of the pencil tanks.

Table 6-2 shows that the worst case ${ }^{240} \mathrm{Pu}$ mass percentage is $11 \%$. The worst case ${ }^{241} \mathrm{Am}$ mass percentage is $1 \%$. These values are consistent with the fact that the pencil tanks were part of a chemical process that produced "fuels grade" and "weapons grade" plutonium. A ${ }^{240} \mathrm{Pu}$ mass percentage of between $6 \%$ and $11 \%$ (as shown in Table 6-1) is consistent with the processing history. This was also confirmed by an engineer that worked with this process.

The mass fraction of ${ }^{240} \mathrm{Pu}$ and ${ }^{241} \mathrm{Am}$ are less than that found in the PFP DSA (see Section 3.1). The basis of the mass fraction for the PFP DSA " $>10 \% \mathrm{Pu}-240 "$ also included plutonium obtained from other sites in the DOE complex that had high ${ }^{240} \mathrm{Pu}$ mass fractions. As a result, the isotopic distribution used in the DSA had greater concentrations of ${ }^{240} \mathrm{Pu}$ and ${ }^{241} \mathrm{Am}$ isotopes.

The isotopic distribution shown in Table 6-1 is used for the analysis of the SWBs that have been shipped. This distribution bounds the data in Table 6-2. A somewhat more bounding distribution is needed because, while it is not likely that the isotopic distribution would be worse, the isotopic distribution of the remaining pencil tanks is not known. The distribution comes from Table 3B-8 of HNF-14741, Solid Waste Operations Complex Master Documented Safety Analysis. The isotopic distribution is conservative relative to "fuels grade' plutonium. The data was based on characterization data from TRU drums (which include primarily "fuels grade" and weapons grade" $\mathrm{Pu}$.

Table 6-1. Bounding Mass Fraction of the Isotopes in the PTOs that have been Shipped

\begin{tabular}{|c|c|}
\hline Isotope & Mass Fraction \\
\hline $\mathrm{Pu}-238$ & 0.0008 \\
\hline $\mathrm{Pu}-239$ & 0.8395 \\
\hline $\mathrm{Pu}-240$ & 0.1297 \\
\hline $\mathrm{Pu}-241$ & 0.011 \\
\hline $\mathrm{Pu}-242$ & 0.0003 \\
\hline $\mathrm{Am}-241$ & 0.0175 \\
\hline
\end{tabular}


CHPRC-01674, Rev. 1

Table 6-2. Inventory and Isotopic distribution for the SWBs containing PTOs that have been shipped.

\begin{tabular}{|c|c|c|c|c|c|c|c|c|c|}
\hline \multirow{2}{*}{$\begin{array}{c}\text { Pencil Tank } \\
\text { Number }\end{array}$} & \multirow[t]{2}{*}{ SWB Number } & \multicolumn{7}{|c|}{ Mass percentage of the indicated isotope } & \multirow{2}{*}{$\begin{array}{c}\text { in the SWB, } \\
\text { grams } \\
\text { (Note 1) }\end{array}$} \\
\hline & & Pu-238 & Pu-239 & Pu-240 & Pu-241 & Pu-242 & Am-241 & Np-237 & \\
\hline$\# 17$ & 0080574 & 0.0221 & 92.9472 & 6.8489 & 0.1250 & 0.0568 & 0.4968 & 0.0232 & $\begin{array}{l}143 \\
\text { (6 PTOs) }\end{array}$ \\
\hline$\# 17$ & 0078296 & 0.0428 & 90.6732 & 8.9430 & 0.2151 & 0.1259 & 0.9013 & 0.0407 & 4 \\
\hline$\# 17$ & 0080819 & 0.0430 & 90.6957 & 8.9138 & 0.2229 & 0.1246 & 0.8954 & na & 5 \\
\hline$\# 20$ & 0080818 & 0.0147 & 93.6069 & 6.2090 & 0.1304 & 0.0390 & 0.2605 & 0.0153 & 15 \\
\hline$\# 24$ & 0080784 & 0.0220 & 93.2094 & 6.5776 & 0.1380 & 0.0530 & 0.4290 & na & 16 \\
\hline \#23 & 0085709 & 0.0240 & 94.0365 & 5.7370 & 0.1583 & 0.0442 & 0.2473 & 0.0087 & 21 \\
\hline$\# 23$ & 0080780 & 0.0196 & 93.7828 & 5.9872 & 0.1576 & 0.0528 & 0.2819 & 0.0105 & $\begin{array}{l}73 \\
(2 \text { PTOs })\end{array}$ \\
\hline$\# 23$ & 0080783 & 0.0176 & 93.1988 & 6.6138 & 0.1222 & 0.0476 & 0.3919 & 0.0158 & 8 \\
\hline$\# 25$ & 0080820 & 0.0270 & 93.9920 & 5.7170 & 0.2441 & 0.0200 & 0.3290 & 0.0270 & 1 \\
\hline$\# 25$ & 0085685 & 0.0270 & 93.9920 & 5.7170 & 0.2441 & 0.0200 & 0.3290 & 0.0270 & 5 \\
\hline$\# 26$ & 0085686 & 0.0098 & 92.6173 & 7.1786 & 0.1539 & 0.0404 & 0.5157 & 0.0321 & 5 \\
\hline$\# 28$ & 0079283 & 0.0447 & 89.2236 & 10.3302 & 0.2451 & 0.1564 & 0.9929 & 0.0413 & $\begin{array}{l}72 \\
(1 \mathrm{PTO})\end{array}$ \\
\hline$\# 28$ & 0080793 & 0.0360 & 88.6442 & 10.9226 & 0.2361 & 0.1611 & 0.9813 & 0.0420 & 25 \\
\hline$\# 28$ & 0078630 & 0.0417 & 88.5015 & 11.0406 & 0.2396 & 0.1766 & 1.0084 & 0.0413 & $\begin{array}{l}176 \\
(1 \mathrm{PTO})\end{array}$ \\
\hline$\# 28$ & 0079284 & 0.0498 & 89.8519 & 9.6225 & 0.3225 & 0.1533 & 1.0039 & 0.0452 & 3 \\
\hline$\# 28$ & $\begin{array}{l}\text { waste } \\
(0082424)\end{array}$ & 0.0242 & 93.5336 & 6.2267 & 0.1648 & 0.0507 & 0.3288 & 0.0130 & -- \\
\hline$\# 27$ & 0080777 & 0.0208 & 93.7682 & 6.0207 & 0.1406 & 0.0497 & 0.1549 & 0.0095 & 26 \\
\hline$\# 15$ & 0080815 & 0.0167 & 93.2940 & 6.5082 & 0.1360 & 0.0451 & 0.2660 & 0.0126 & 11 \\
\hline$\# 41$ & 0080814 & 0.0307 & 90.9894 & 8.7067 & 0.1727 & 0.1005 & 0.6348 & 0.0292 & 3 \\
\hline$\# 42$ & 0080817 & 0.0187 & 94.2854 & 5.5417 & 0.1180 & 0.0362 & 0.3417 & 0.0177 & 3 \\
\hline$\# 45$ & 0080816 & 0.0419 & 92.0353 & 7.6672 & 0.1690 & 0.0866 & 0.5538 & 0.0270 & 7 \\
\hline
\end{tabular}


CHPRC-01674, Rev. 1

Table 6-2. Inventory and Isotopic distribution for the SWBs containing PTOs that have been shipped.

\begin{tabular}{|c|c|c|c|c|c|c|c|c|c|}
\hline \multirow{2}{*}{$\begin{array}{c}\text { Pencil Tank } \\
\text { Number }\end{array}$} & \multirow[t]{2}{*}{ SWB Number } & \multicolumn{7}{|c|}{ Mass percentage of the indicated isotope } & \multirow{2}{*}{$\begin{array}{c}\text { in the SWB } \\
\text { grams } \\
\text { (Note 1) }\end{array}$} \\
\hline & & Pu-238 & Pu-239 & Pu-240 & Pu-241 & Pu-242 & Am-241 & Np-237 & \\
\hline$\# 45$ & 0078629 & 0.0309 & 90.9474 & 8.7754 & 0.1582 & 0.0881 & 0.5409 & 0.0239 & 11 \\
\hline$\# 36$ & 0078636 & 0.0270 & 93.9920 & 5.7170 & 0.2441 & 0.0200 & 0.3290 & 0.0270 & 3 \\
\hline$\# 46$ & 0078637 & 0.0285 & 92.1275 & 7.5948 & 0.1723 & 0.0769 & \begin{tabular}{|l|}
0.7679 \\
\end{tabular} & 0.0369 & 24 \\
\hline$\# 49$ & 0080792 & 0.0448 & 91.1590 & 8.4464 & 0.2336 & 0.1162 & 0.6789 & 0.1393 & 3 \\
\hline$\# 49$ & $\begin{array}{l}\text { waste } \\
(0082600)\end{array}$ & 0.0270 & 93.9920 & 5.7170 & 0.2441 & 0.0200 & 0.3290 & 0.0270 & --- \\
\hline$\# 128$ & 0081120 & 0.0262 & 93.1486 & 6.6270 & 0.1394 & 0.0588 & 0.4436 & 0.0178 & 5 \\
\hline$\# 18$ & 0085703 & 0.0278 & 92.0368 & 7.6923 & 0.1733 & 0.0698 & 0.5625 & 0.0236 & 2 \\
\hline$\# 18$ & 0085702 & 0.0368 & 92.5683 & 7.1367 & 0.1879 & 0.0703 & 0.6037 & na & 23 \\
\hline$\# 18$ & 0085716 & 0.0141 & 92.6340 & 7.0816 & 0.2227 & 0.0476 & 0.7360 & na & 1 \\
\hline$\# 19$ & 0080627 & 0.0270 & 93.9920 & 5.7170 & 0.2441 & 0.0200 & 0.3290 & 0.0270 & 3 \\
\hline$\# 19$ & 0080775 & 0.0234 & 93.6197 & 6.1208 & 0.1705 & 0.0656 & 0.4629 & na & 1 \\
\hline$\# 19$ & 0080628 & \begin{tabular}{|l|}
0.0407 \\
\end{tabular} & 92.9247 & 6.8325 & 0.1247 & \begin{tabular}{|l|}
0.0774 \\
\end{tabular} & \begin{tabular}{|l|}
0.6938 \\
\end{tabular} & na & 2 \\
\hline$\# 39$ & 0078936 & 0.0218 & 93.6357 & 6.1558 & 0.1404 & 0.0463 & 0.3155 & 0.0150 & 10 \\
\hline \#39 & 0078951 & 0.0185 & 94.0224 & 5.7684 & 0.1518 & 0.0389 & 0.4205 & 0.0223 & 38 \\
\hline \#37 & 0078950 & 0.0204 & 93.8110 & 5.9702 & 0.1550 & 0.0434 & 0.2481 & 0.0069 & $\begin{array}{l}56 \\
\text { (5 PTOs) }\end{array}$ \\
\hline \#37 & 0078938 & 0.0214 & 94.0816 & 5.7000 & 0.1559 & 0.0411 & 0.2822 & 0.0124 & 28 \\
\hline$\# 37$ & 0078940 & 0.0262 & 92.6611 & 7.0846 & 0.1530 & 0.0751 & 0.3759 & 0.0166 & 11 \\
\hline$\# 38$ & 0078949 & 0.0275 & 93.5282 & 6.2199 & 0.1702 & 0.0542 & 0.3292 & 0.0113 & 2 \\
\hline \#38 & 0078937 & 0.0226 & 93.9496 & 5.8262 & 0.1577 & 0.0439 & 0.3022 & 0.0147 & 15 \\
\hline$\# 40$ & 0081116 & 0.0270 & 93.9920 & 5.7170 & 0.2441 & 0.0200 & 0.3290 & 0.0270 & 3 \\
\hline$\# 40$ & 0081117 & 0.0467 & 91.3879 & 8.2551 & 0.1962 & 0.1141 & 0.6140 & na & 3 \\
\hline
\end{tabular}

Note 1: The data provides the number of PTOs for each of the SWBs listed. This author has chosen only indicate the number of PTOs for the high inventory SWBs. 
The discussion that follows shows the hydrogen pathway out of the SWB and provides the basis for the diffusivities used in the analysis

\section{Hydrogen Transport through the MMC into the sonotube}

The MMC is metal with an open top and a screen on the bottom. As a result, there is no resistance to flow of hydrogen from the MMC to the sonotube. Therefore, the hydrogen concentration within the MMC is the same as the concentration within the sonotube.

\section{Hydrogen Diffusion through the Sonotube into the Bag around the Sonotube}

Hydrogen diffusion through the sonotube walls is small and is ignored. This is because the sonotube is a multilayer dense cardboard tube that appears to have a finish on the inside. As a result, the path for the hydrogen transport out of the sonotube is by diffusion through the spacer cushion itself, through the gap between the cushion and the sonotube walls, and through the gap between the wood plug at the base of the sonotube and the sonotube wall. Typically, hydrogen diffusion through the gaps exceeds the diffusion through the cushion itself.

The sonotube cushion and wood plug are sized to fit snugly in the sonotube. A number of sonotube cushions have been purchased and stored in a warehouse for later use. A review of the sonotube cushions stored in the warehouse showed diameters between 14.5 in. and just over 14 in. Most of the cushions were 14.5 in. in diameter. The sonotube has a diameter of 14 in. As a result, all of the cushions have to be "stuffed" into the sonotube and, therefore, fit snugly. The work package, 2Z-10-0184-045-00 (also shown in Drawing H-2-836485), shows that the wood plugs were to be cut to fit snugly within the sonotube and nailed in place. A review of the sonotubes in the warehouse that had wood plugs attached showed that the fit was snug.

The snug fit was modeled as an equivalent gap of 2 mil or 0.002 in. between the sonotube cushion and the sonotube wall, all the way around. This means that the size of the actual gap varies between 0 in. and to greater than 2 mils. A 2-mil gap is about equal in size to half the thickness of a human hair, half the thickness of a dollar bill or half the thickness of a sheet of copy paper (http://hypertextbook.com/facts/index-topics.shtml). This is considered reasonable because the wood plug was fabricated from a larger piece of wood and, as such, is not perfectly smooth or perfectly round. Since the cushion is pressed into the sonotube in a number of steps (press in a portion of the cushion, go to another location on the sonotube and press in again, etc., until the sonotube cushion is in place), there will be small wrinkles in the cushion that create gaps between the sonotube and the cushion.

Appendix $\mathrm{C}$ of this document and Appendix C of HNF-16166 provide a method to determine the diffusivity through an opening in a container. The method is based on a heat transfer analogy equating one-dimensional heat flow with diffusion flow. The resistance of the opening is found first, with the diffusivity found using the resistance.

Using HNF-16166, Appendix C, the resistance of the gap around the plug in the sonotube is found to be:

$$
\mathrm{R}=\frac{x}{A D}=\frac{5.08 \mathrm{~cm}}{\left(0.567 \mathrm{~cm}^{2}\right) *(0.75 \mathrm{~cm} / \mathrm{s})} * \frac{1000 \mathrm{~cm}^{3}}{\mathrm{~L}}=11,940 \mathrm{~s} / \mathrm{L}
$$


where:

$$
\begin{aligned}
\mathrm{x}= & \text { length of flow path, } \mathrm{cm} \\
= & 5.08 \mathrm{~cm}(2 \mathrm{in} .) \\
\mathrm{A}= & \text { cross-sectional area of the flow path, } \mathrm{cm}^{2} \\
= & 0.567 \mathrm{~cm}^{2} \text { (from the area between a } 14 \text { in. diameter circle and a } 13.996 \text { in. } \\
& \text { diameter circle representing the equivalent diameter of the sonotube cushion and } \\
& \text { wood plug.) } \\
\mathrm{D}= & \text { diffusivity of hydrogen in air, } \mathrm{cm}^{2} / \mathrm{s} \\
= & 0.75 \mathrm{~cm}^{2} / \mathrm{s} .
\end{aligned}
$$

The diffusivity of hydrogen through the gaps in the sonotube cushion is found from:

$$
\frac{1}{\mathrm{R} * 24.45 \mathrm{~L} / \mathrm{mole}} \text { or } \frac{1}{(11940 \mathrm{~s} / \mathrm{L}) *(24.45 \mathrm{~L} / \text { mole })}=3.43 \times 10^{-6} \frac{\text { moles }}{\mathrm{s}-\text { mole fraction }}
$$

The method of HNF-16166, Appendix B, is used in the subsection titled "Manufacturer's Data and the Resistance Calculation" of HNF-16166, Appendix C, to determine the diffusivity of the Nuclear Filter Technology ("NucFil") Model 007LS filter. The calculated diffusivity was found to be 1.06 times greater than the manufacturer's value, a good result for this complicated filter. As a result, the method shown above is a reasonable way to determine the diffusivity of an open path.

The wood plug is about 0.75 -in. thick. Assume that it is 1 -in. thick, to cover uncertainties. The wood plug is nailed to the sonotube in eight places. Assume that the gap is equivalent to a 2-mil (0.002 in.) gap all around the plug. Using the method above:

$$
\begin{aligned}
& \qquad \begin{aligned}
& R=\frac{x}{A D}= \frac{2.54 \mathrm{~cm}}{\left(0.567 \mathrm{~cm}^{2}\right) *(0.75 \mathrm{~cm} / \mathrm{s})} * \frac{1000 \mathrm{~cm}^{3}}{\mathrm{~L}}=5970 \mathrm{~s} / \mathrm{L} \\
& \text { Diffusivity of } H_{2} \text { thru gap in wood plug } \\
&=\frac{1}{\mathrm{R} * 24.45 \mathrm{~L} / \mathrm{mole}} \text { or } \frac{1}{(5970 \mathrm{~s} / \mathrm{L}) *(24.45 \mathrm{~L} / \mathrm{mole})} \\
&=6.85 \times 10^{-6} \frac{\text { moles }}{\mathrm{s}-\text { mole fraction }}
\end{aligned}
\end{aligned}
$$

The diffusivity is proportional to the inverse of the resistance. To obtain the resistance for a parallel path, the effective resistance is found from:

$$
\frac{1}{R_{\text {eq }}}=\frac{1}{R_{\text {cushion }}}+\frac{1}{R_{\text {wood base }}}
$$




$$
\text { Diffusivity }_{\text {equivalent }}=\text { Diffusivity }_{\text {cushion }}+\text { Diffusivity }_{\text {wood base }}
$$

As a result, the total diffusivity out of the sonotube is $1.03 \times 10^{-5} \mathrm{moles} / \mathrm{s}-\mathrm{mole}$ fraction (from $3.42 \times 10^{-6}$ plus $\left.6.85 \times 10^{-6}\right)$.

\section{Hydrogen Diffusion through the Sonotube Cushion into the Bag around the Sonotube}

Diffusion occurs through the spacer cushion. The spacer cushion is made of AP/ARMAFLEX Pipe Insulation. Based on the manufacturer's data sheet, AP/ARMAFLEX is a closed cell elastomeric foam based on a synthetic rubber. The constituents of AP/ARMAFLEX are not provided. No data is provided for the permeability of hydrogen through AP/ARMAFLEX.

The permeability for hydrogen through AP/ARMAFLEX is inferred from a comparison of the permeability of water vapor and hydrogen in various elastomers (rubbers). The data on the permeability of water vapor through elastomers comes from EPA-600/2-79-038, Table 4, "Liner Materials Exposed to Municipal Solid Waste Leachate - Third Interim Report." The hydrogen permeability data comes from Table 3-24 of the Parker O-Ring Handbook. Other data comes from Table 2.2 and 2.3 of SAND2006-1163, Technical Reference on Hydrogen Compatibility of Material, Chapter 8100, "Polymers of the Technical Reference on Hydrogen Compatibility of Materials." The data is shown in Table 6-3, Data on Water Vapor and Hydrogen Permeability.

The data in Table 6-3 shows the permeability of water vapor through the rubber is about a factor of 1 to 10 times greater than for hydrogen. Permeability is a function of diffusivity and solubility. While the diffusivity of hydrogen is typically higher than most gases or vapors, the combination of diffusivity and solubility can result in the permeability being lower.

To model hydrogen permeation through the spacer cushion, the permeability of water vapor of $2.1 \times 10^{-6} \frac{\mathrm{cm}^{3}-\mathrm{cm}}{\mathrm{s}-\mathrm{cm}^{2}-\mathrm{cmHg}}$ is divided by 10 to obtain the permeability of hydrogen through the material as this, which results in the smallest value.

The cushion is $2 \mathrm{in}$. $\left(5.08 \mathrm{~cm}\right.$ ) thick. The area is $993 \mathrm{~cm}^{2}$ (based on a diameter of $13.996 \mathrm{in}$.). Using this, the diffusivity is:

$$
\begin{gathered}
2.1 \times 10^{-7} \frac{\mathrm{cm}^{3}-\mathrm{cm}}{\mathrm{s}-\mathrm{cm}^{2}-\mathrm{cm} \mathrm{Hg}} *\left(\frac{993 \mathrm{~cm}^{2}}{5.08 \mathrm{~cm}}\right) * 76 \mathrm{~cm} \mathrm{Hg} *\left(\frac{\text { moles }}{24450 \mathrm{~cm}^{3}}\right) \\
=1.27 \times 10^{-7} \frac{\text { moles }}{\mathrm{s}-\text { mole fraction }}
\end{gathered}
$$

Diffusion through the gaps is much greater than diffusion through the cushion itself. As a result, the diffusivity through the sonotube cushion is neglected. 
Table 6-3. Data on Water Vapor and Hydrogen Permeability

\begin{tabular}{|c|c|c|c|c|c|c|c|c|}
\hline \multirow[t]{2}{*}{ Material } & \multicolumn{3}{|c|}{$\begin{array}{c}\text { Data from the EPA on Water Vapor } \\
\text { Permeability }\end{array}$} & \multicolumn{2}{|c|}{$\begin{array}{c}\text { Data on Hydrogen } \\
\text { Permeability from Parker } \\
\text { O-Ring Handbook }\end{array}$} & \multicolumn{2}{|c|}{$\begin{array}{c}\text { Data on Hydrogen } \\
\text { Permeability from Technical } \\
\text { Reference... }\end{array}$} & \multirow{2}{*}{$\begin{array}{c}\text { Water Vapor } \\
H_{2} \\
\text { (Column } 4 \\
\text { divided by } \\
\text { Column } 6 \text { or } \\
\text { Column } 8 \text { ) }\end{array}$} \\
\hline & $\begin{array}{l}\text { Thickness } \\
\text { of sample, } \\
\text { cm }\end{array}$ & $\begin{array}{l}\text { Permeability, } \\
\frac{\text { grams-cm }}{d-m^{2}-m m H g}\end{array}$ & $\begin{array}{l}\text { Permeability, } \\
\frac{g r a m s-c m}{s-c m^{2}-c m H g}\end{array}$ & $\begin{array}{l}\text { Permeability, } \\
\frac{c m^{3}-c m}{s-c m^{2}-b a r}\end{array}$ & $\begin{array}{l}\text { Permeability, } \\
\frac{g r a m s-c m}{s-c m^{2}-c m H g}\end{array}$ & $\begin{array}{l}\text { Permeability, } \\
\frac{\mathrm{mol} \mathrm{H}_{2}}{s-m-M P a}\end{array}$ & $\begin{array}{l}\text { Permeability, } \\
\frac{\text { grams-cm }}{s-c m^{2}-c m H g}\end{array}$ & \\
\hline \multirow{2}{*}{$\begin{array}{l}\text { Butyl } \\
\text { Rubber }\end{array}$} & 0.185 & $1.39 \mathrm{E}-3$ & $2.18 \mathrm{E}-08$ & $1.61 \mathrm{E}-07$ & $2.15 \mathrm{E}-09$ & & & 10 \\
\hline & 0.085 & $0.15 \mathrm{E}-3$ & $2.36 \mathrm{E}-09$ & & & & & \\
\hline \multirow[t]{2}{*}{ Neoprene } & 0.159 & $2.89 \mathrm{E}-3$ & $4.54 \mathrm{E}-08$ & $1.80 \mathrm{E}-06$ & $2.40 \mathrm{E}-08$ & $9.24 \mathrm{E}-9$ & $3.01 \mathrm{E}-9$ & $\begin{array}{l}1.9 \text { and } \\
15\end{array}$ \\
\hline & 0.051 & $1.22 \mathrm{E}-3$ & $1.92 \mathrm{E}-08$ & & & & & \\
\hline \multirow[t]{2}{*}{$\begin{array}{l}\text { Ethylene- } \\
\text { Propylene }\end{array}$} & 0.17 & $2.52 \mathrm{E}-3$ & $3.96 \mathrm{E}-08$ & $2.90 \mathrm{E}-07$ & $3.87 \mathrm{E}-09$ & $\begin{array}{l}6.96 \mathrm{E}-9 \\
\text { (From EPDM) }\end{array}$ & $2.27 \mathrm{E}-9$ & $\begin{array}{l}10 \text { and } \\
17.4\end{array}$ \\
\hline & 0.051 & $1.09 \mathrm{E}-3$ & $1.71 \mathrm{E}-08$ & & & & & \\
\hline Hypalon & 0.079 & $3.97 \mathrm{E}-3$ & $6.23 \mathrm{E}-08$ & & & $3.68 \mathrm{E}-9$ & $1.2 \mathrm{E}-9$ & 52 \\
\hline $\begin{array}{l}\text { AP/ } \\
\text { Armaflex }\end{array}$ & 5.08 & $\begin{array}{l}1.16 E-13 \frac{\mathrm{kg}}{\mathrm{s-m-Pa}} \\
\text { (Note 1) }\end{array}$ & $\begin{array}{l}1.5 \mathrm{E}-9 \\
\text { (Note } 2)\end{array}$ & & & & & \\
\hline
\end{tabular}

Notes:

Data from manufacturer

Permeability is $2.1 \mathrm{E}-6 \frac{\mathrm{cm}^{3}-\mathrm{cm}}{\mathrm{s}-\mathrm{cm}^{2}-\mathrm{cmHg}}$, using $18 \mathrm{~g} / \mathrm{mole}, 24,450 \mathrm{~cm}^{3} / \mathrm{mole}$ and $101,320 \mathrm{~Pa} / 76 \mathrm{cmHg}$. 
A sketch of the bag around the sonotube shows that it is made of two plastic sheets, cut to size and heat-sealed together at the edges. Since only small PTOs are assumed to be loaded, the description of the bag involves only that for the small PTO.

Figure 6-2, Sonotube Bag Sheet, shows the sonotube bag sheet for the small PTO. The bag sheet is 103 in. long. The portion of the sheet containing the lower portion of the bag is 25.25- in. wide. The lower portion of the bag sheet is $52 \mathrm{in}$. long. The width of the bag sheet increases to 32 in. over a length of 21 inches and then remains 32 inches wide for the last 30 inches. When the two sheets are placed together and the edges welded, the diameter of the lower portion becomes $15 \mathrm{in}$. (allowing for a 0.50 -in. seal on both edges). The diameter of the upper portion becomes 20 inches. The 52-in. long portion is what the sonotube is placed into. The upper portion is used in the twist and tape portion. The PTO is 45 in. long. The twisted length is about 51 in. long (from 103 in. minus 52 in.). The length is twisted, taped, and cut so it will fit into the PTO.

FLAT LAY OUT OF 20" diameter to 15" diameter reduction bag for PRF Canyon Seal outs

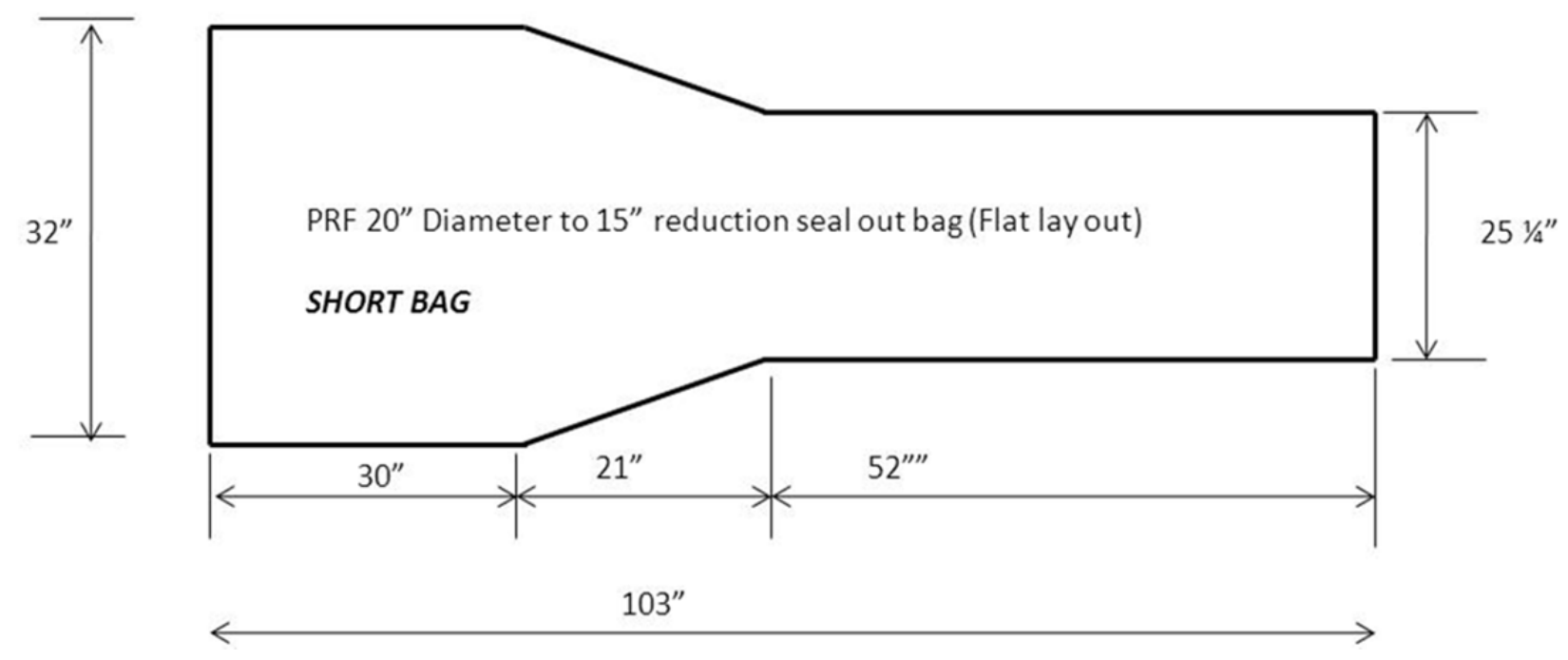

\section{Figure 6-2. Sonotube Bag Sheet}

Drawing of sheet from which the Sonotube Bag is made

The analysis uses a diffusivity found from WIPP tests on drum liner bags on the recommendation from WIPP that it is acceptable for use. This is discussed next. 
In the TRUCON Code, WIPP characterized the bag as a large drum liner bag. This bag was tested in Appendix 6.8 of the CH-TRU Payload Appendices. The bag fit into a 55-gallon drum, which is 23 in. in diameter and 34 in. tall. In discussions with CHPRC, WIPP said that any bag that has a surface area greater than $1.6 \mathrm{~m}^{2}$ can be considered a drum liner bag. (See Appendix G.2)

The portion of the bag that contains the sonotube is $15 \mathrm{in.}$ in diameter and $52 \mathrm{in.} \mathrm{long.} \mathrm{During}$ and immediately after twisting and taping, the bag is cylinder shaped with a cone on top. The cylinder is $15 \mathrm{in}$. in diameter and $45 \mathrm{in.} \mathrm{long.} \mathrm{The} \mathrm{cone} \mathrm{is} \mathrm{the} \mathrm{region} \mathrm{between} \mathrm{the} \mathrm{top} \mathrm{of} \mathrm{the}$ sonotube and the twist and taped portion. It exists while the twisting and taping is proceeding. After the twist and tape is made, the twist and tape portion is laid on top of the sonotube cushion. Using a diameter of 15 inches and a height of 45 inches, the surface area of the cylindrical portion of the sonotube bag is $1.37 \mathrm{~m}^{2}$.

The sonotube bag surface area also includes additional surface area of the cone of bag material (containing the twist and tape section) that is laid on top of the sonotube cushion. The cone section is $7.5 \mathrm{in}$. in radius (the radius of the sonotube bag). The cone height is 7 inches tall (from 52 inches long minus 45 inches tall sonotube). The surface area is given by

$$
\text { Surface area of a cone }=\pi * r * s
$$

where "s" is the length of the face of the cone and " $r$ " is the radius of the base.

For the case described, "s" is $10.3 \mathrm{in.}$ and " $\mathrm{r}$ " is $7.5 \mathrm{in}$. This gives an area of the cone in the sonotube bag above the sonotube of $242 \mathrm{in}^{2}$ or $0.156 \mathrm{~m}^{2}$. However, the cone contains pleats from where the bag was gathered. The area of the cone plus the pleats is approximated by the area of the sides and top of a cylinder that is 7.5 inches in radius and 7 inches tall or $507 \mathrm{in}^{2}$ or $0.327 \mathrm{~m}^{2}$.

The PTO is laid on its side in the SWB. As a result, there is additional diffusion area from the base of the sonotube bag. The area is $177 \mathrm{in}^{2}$ or $0.114 \mathrm{~m}^{2}$ (from a 15-inch diameter sonotube bag). The total surface area of the sonotube bag is $1.37 \mathrm{~m}^{2}+0.327 \mathrm{~m}^{2}+0.114 \mathrm{~m}^{2}=1.8 \mathrm{~m}^{2}$. Since the area for diffusion is greater than $1.6 \mathrm{~m}^{2}$, the diffusivity from WIPP can be used.

The diffusivity from WIPP for liner bags comes from Appendix 6.8 of the CH-TRU Payload Appendices. Appendix 6.8 shows the diffusivities of various drum liner bags inside a 55-gallon drum containing a hydrogen generation source. Eighteen drum liner bags were tested. Each had a twist and tape closure. About half of these bags were 10-mil in thickness and the other half were 14-mil thick. The diameter and height varies somewhat, although all were either the outermost liner bag or the second-to-the-outermost liner bag (just inside the 90-mil high density polyethylene (HDPE) drum liner). The resulting diffusivities varied from 4.04E-6 to 2.3E-5 for essentially the same sized bag with the same twist and tape closure. The tests show that the combination of diffusion through the bag surface and twist and tape does not produce a single diffusivity value, but a range of values. WIPP conservatively chose a diffusivity of the drum liner bag, with the twist and tape closure that is near the bottom of the diffusivities found (4.67 $\mathrm{x}$ $10^{-6}$ moles/s-mole fraction) (Appendix 6.8.1 of CH-TRU Payload Appendices). 
The WIPP value of diffusivity of 4.76E-6 moles/s-mole fraction is used in the analysis based on the surface area of the sonotube bag being $1.6 \mathrm{~m}^{2}$ and based on statements by WIPP personnel concerning the use of 4.67E-6 moles/s-mole fraction. The e-mail is in Appendix G.

\section{Hydrogen transport through the PTO}

The PTO has a NucFil -013 filter in it. The diffusivity of the filter is $1.1 \times 10^{-5} \mathrm{moles} / \mathrm{s}-\mathrm{mole}$ fraction per manufacturer's datasheet found in HNF-16166, Appendix A, page A-5.

The TRUCON Code for this waste package assumes that the PTO filter diffusivity is a minimum of $3.7 \times 10^{-6} \mathrm{moles} / \mathrm{s}-\mathrm{mole}$ fraction. Since the filter diffusivity is greater than the WIPP minimum diffusivity, it is acceptable for use.

\section{Hydrogen transport through the SWB}

The SWB contains two NucFil-019DS filters. The diffusivity of the NucFil-019DS filter is $1.85 \times 10^{-5} \mathrm{moles} / \mathrm{s}$-mole fraction. This value is taken from the 2008 Manufacturer's datasheet for this filter. The Nucfil-019DS filter is a " $5 X$ " filter per the Manufacturer's webpage. Appendix D of this report shows that the diffusivity of a " $5 \mathrm{X}$ " filter is $1.85 \times 10^{-5} \mathrm{moles} / \mathrm{s}$-mole fraction. The diffusivity was confirmed in telephone conversations with WIPP personnel. The total diffusivity of the two filters is $3.7 \times 10^{-5} \mathrm{moles} / \mathrm{s}$-mole fraction.

The TRUCON Code for this waste package assumes that the SWB filter diffusivity is a minimum of $18.5 \times 10^{-6}$ (or $1.85 \times 10^{-5}$ ) moles/s-mole fraction. Since the filter diffusivity is greater than the WIPP minimum diffusivity, it is acceptable for use.

\section{$\mathbf{G}\left(\mathbf{H}_{2}\right)$}

A comparison of Tables 6-2 and 6-4 (that follows) shows that only one SWB contains an inventory that might exceed the inventory limits. That is SWB 00785630 (PTO \#28) which has $173 \mathrm{~g}$ in one PTO. Tank 28 is the solids recycle tank (although there were no solids recycled in PRF. The tank received both acid and organic solutions of interface crud and backwash solutions. The tanks have been out of service for more than 30 years (last ran in the 1970's based on personal communication with Ted Venetz, former PFP Process Engineer). An indication of this is the September 1980 version of the PRF Engineering Training Manual (RHO-MA-246), which does not have Tank 28 in its list of PRF tanks. Since the tank received both organic and acid solutions, it is assumed that the tank contained organics. The organics used were tributyl phosphate (TBP) and carbon tetrachloride $\left(\mathrm{CCl}_{4}\right)$. This is conservative as the value of $\mathrm{G}\left(\mathrm{H}_{2}\right)$ for organics is greater than that for acid that has been drying for 30 years.

Table 3-1 shows that the waste type that best fits the waste in Tank 28 is Waste Material type III.1. The matrix depleted value of $\mathrm{G}\left(\mathrm{H}_{2}\right)$ is 1.09 . This value can also be used for the rest of the pencil tanks that had organic solutions run through them. Matrix depleted values can be used as the watt-hr criterion is satisfied quickly with an inventory of $173 \mathrm{~g}$.

Other pencil tanks had acid as the process solution, the value for $\mathrm{G}\left(\mathrm{H}_{2}\right)$ for dried acid is much lower than 1.09 because the acid concentrates as it dries (See Section 3.1.3.4 of CH-TRU Payload Appendices).

Some of the columns are packed with plastic rings. Most are Kynar, but some are polypropylene. Some tanks are also lined with Kynar. The G-value for and chemical structure 
of polypropylene is very similar to that for polyethylene. After matrix depletion, the value of $\mathrm{G}\left(\mathrm{H}_{2}\right)$ for polyethylene is about half that used in the analysis. Because of the structural similarities, the value of $\mathrm{G}\left(\mathrm{H}_{2}\right)$ of polypropylene, after matrix depletion, is also less than that used in the analysis.IN addition, radioactive material on polypropylene is a Waste Material III.1.

The G-value of Kynar (polyvinylidene fluoride) is not provided, but appears, by the chemical constituents, to be less that polyethylene. Kynar is polyvinylidene fluoride. The structure is the same as that for polyethylene, except that every other carbon atom in the backbone contains two fluoride atoms instead of hydrogen. Radiolysis will release less hydrogen and some fluoride or HF. As a result, it is bounded by the value of $\mathrm{G}\left(\mathrm{H}_{2}\right)$ used in the analysis.

The value of $\mathrm{G}\left(\mathrm{H}_{2}\right)$ of 1.09 is used in the analysis of SWBs that have been shipped. The inventory limits that come from that analysis will show that the inventories in the other SWBs bounded by the calculated allowable inventories.

\section{Summary of the Diffusion through the PTO in an SWB waste package - Previously Shipped SWBs}

The results of the analysis are shown in Tables 6-4, Diffusion through the PTO in an SWB waste package - Previously Shipped SWBs. The diffusivities are input (or calculated and then input) along with the other data necessary to solve the equations. The isotopic distribution from Table 6-1 is used as is the value of $\mathrm{G}\left(\mathrm{H}_{2}\right)$ of 1.09 (See subsection " $\mathrm{G}\left[\mathrm{H}_{2}\right]$ " above). The inventory is varied such that the hydrogen concentration in the sonotube bag is 4.8 percent (to be conservative relative to the 5 percent limit).

Table 6-4. Diffusion through the PTO in an SWB waste package - Previously Shipped SWBs

\begin{tabular}{|l|l|}
\hline \multicolumn{1}{|c|}{ Path } & \multicolumn{1}{|c|}{ Input Diffusivity } \\
\hline $\begin{array}{l}\text { From inside sonotube to } \\
\text { outside sonotube } \\
\text { (Cell D15) }\end{array}$ & $\begin{array}{l}1.03 \mathrm{E}-5 \\
\text { (based on 2-mil gap between sonotube and cushion and between sonotube and wood } \\
\text { plug) }\end{array}$ \\
\hline $\begin{array}{l}\text { From outside sonotube, } \\
\text { through sonotube bag to } \\
\text { inside PTO } \\
\text { (Cell E15) }\end{array}$ & $\begin{array}{l}\text { 4.67E-6 } \\
\text { (Using diffusivity from WIPP bag test) }\end{array}$ \\
\hline $\begin{array}{l}\text { From inside PTO to } \\
\text { outside PTO } \\
\text { (Cell F15) }\end{array}$ & $\begin{array}{l}1.1 \mathrm{E}-5 \\
\text { (NucFil-013 filter) }\end{array}$ \\
\hline $\begin{array}{l}\text { From outside PTO to } \\
\text { outside SWB liner } \\
\text { (Cell G15) }\end{array}$ & $\begin{array}{l}1.0 \\
\text { (No liner) }\end{array}$ \\
\hline $\begin{array}{l}\text { From outside SWB liner to } \\
\text { outside SWB } \\
\text { (Cell H15) }\end{array}$ & $\begin{array}{l}3.7 \mathrm{E}-5 \\
\text { (Two NucFil-019DS filters) }\end{array}$ \\
\hline $\begin{array}{l}\text { Number of PTOs in the } \\
\text { SWB } \\
\text { (Cell D16) }\end{array}$ & Grams of Pu in each PTO (See Note) \\
\hline
\end{tabular}


Table 6-4. Diffusion through the PTO in an SWB waste package - Previously Shipped SWBs

\begin{tabular}{|c|c|}
\hline Path & Input Diffusivity \\
\hline 6 & 165 grams per PTO \\
\hline 3 & 194 grams per PTO \\
\hline 1 & 218 grams per $\mathrm{PTO}$ \\
\hline $\begin{array}{ll}\text { Notes: } & \\
\text { - } & \text { Grams o } \\
& \text { (Change } \\
\text { - } & \mathrm{G}(\mathrm{H} 2) \text { is } \\
\text { - } & \text { Isotopic } \\
& 2 \text { ). } \\
\text { - No Bag } 1\end{array}$ & $\begin{array}{l}\text { PTO such that the hydrogen concentration in the sonotube is less than } 5 \% \text { ( } 4.8 \% \text { used in analysis) } \\
1 \text { D } 26 \text { until Cell D } 40 \text { reads } 0.0480) \\
\text { is taken from Table } 6-1 \text {, which bounds the isotopic values of the PTOs shipped (shown in Table 6- } \\
\text { onotube bag. }\end{array}$ \\
\hline
\end{tabular}

The results show that the inventory within the PTOs that have been shipped is below the limits shown in Table 6-4. The SWB with one PTO having $173 \mathrm{~g}$ is below the allowable inventory of $218 \mathrm{~g}$. The SWB with $143 \mathrm{~g}$ has six PTOs. Assuming each PTO has about the same inventory, the inventory in each PTO is well below the allowable inventory of $165 \mathrm{~g}$. If one PTO had a large fraction of the inventory, it is still below the allowable inventory of $165 \mathrm{~g}$. All of the other SWBs have, at most, $73 \mathrm{~g}$ in multiple PTOs. As a result, the hydrogen concentration within the sonotube of all of the shipped SWBs is below 5 percent.

\subsubsection{Hydrogen Concentration in the Sonotube of SWBs Shipped in the Future with a Bag Filer in the Sonotube Bag and with Hole in the Sonotube Cushion}

The intent for future shipments is to put a bag filter in the sonotube bag, increase hydrogen diffusion through the sonotube bag, and put a hole in the sonotube cushion so as to create an engineered pathway for hydrogen diffusion through the sonotube.

The isotopic distribution used in the analysis is that shown in Table 3-2 which is the bounding value from the PFP DSA.

The assumptions, calculations and descriptions from Section 6.2.2 are used here unless noted below.

\section{Hydrogen transport through the hole in the sonotube cushion.}

In most sonotube cushions, a hole will be made in the sonotube cushion such that a 2.5 -in. diameter Schedule 80 PVC pipe nipple can be inserted. This will result in a 2.3 -in. diameter hole in the sonotube. The opening will be assumed to be 2.25 inches in diameter to be conservative. The pipe nipple is 2.5 inches long. To be conservative, the pipe length will be assumed to be 2.75 inches.

The diffusivity through the holes is found as follows: 
Using HNF-16166, Appendix C, the resistance of the hole through the sonotube cushion is found to be:

$$
\mathrm{R}=\frac{x}{A D}=\frac{6.98 \mathrm{~cm}}{\left(25.65 \mathrm{~cm}^{2}\right) *(0.75 \mathrm{~cm} / \mathrm{s})} * \frac{1000 \mathrm{~cm}^{3}}{\mathrm{~L}}=363 \mathrm{~s} / \mathrm{L}
$$

where:

$$
\begin{aligned}
\mathrm{x} & =\text { length of flow path, } \mathrm{cm} \\
& =6.98 \mathrm{~cm}(2.75 \text { inches is the length of the pipe nipple) } \\
\mathrm{A} & =\text { cross-sectional area of the flow path, } \mathrm{cm}^{2} \\
& =25.65 \mathrm{~cm}^{2} \text { (from the area of a } 2.25 \text {-inch diameter hole.) } \\
\mathrm{D} & =\text { diffusivity of hydrogen in air, } \mathrm{cm}^{2} / \mathrm{s} \\
& =0.75 \mathrm{~cm}^{2} / \mathrm{s} .
\end{aligned}
$$

The diffusivity of hydrogen through the gaps in the sonotube cushion is found from:

$$
\frac{1}{\mathrm{R} * 24.45 \mathrm{~L} / \mathrm{mole}} \text { or } \frac{1}{(363 \mathrm{~s} / \mathrm{L}) *(24.45 \mathrm{~L} / \mathrm{mole})}=1.13 \times 10^{-4} \frac{\text { moles }}{s-\text { mole fraction }}
$$

The diffusivity out of the hole in the sonotube cushion is $1.13 \times 10^{-4} \mathrm{moles} / \mathrm{s}$-mole fraction.

\section{Hydrogen transport through the hole in the sonotube walls}

In some cases, there is no hole in the sonotube cushion. In these cases, 0.5 -in. diameter holes will be drilled into the sonotube wall at about the elevation of the holes in the MMC. There will be four of them equally spaced around the sonotube. The number of holes takes into account the fact that when the PTO is laid on its side in the SWB, the sonotube may be oriented such that one hole is "blocked", meaning the sonotube is laying such that a hole is against the bag which is against the PTO. In this orientation, diffusion through that hole will be greatly reduced, but diffusion can continue through the other three holes.

The diffusivity through the holes is found as follows:

Using HNF-16166, Appendix C, the resistance of the hole through the sonotube wall is found to be:

$$
\mathrm{R}=\frac{x}{A D}=\frac{0.635 \mathrm{~cm}}{\left(1.27 \mathrm{~cm}^{2}\right) *(0.75 \mathrm{~cm} / \mathrm{s})} * \frac{1000 \mathrm{~cm}^{3}}{\mathrm{~L}}=667 \mathrm{~s} / \mathrm{L}
$$

where: 
$\mathrm{x}=$ length of flow path, $\mathrm{cm}$

$=0.635 \mathrm{~cm}(0.25 \mathrm{in}$. the thickness of the sonotube wall $)$

$\mathrm{A}=$ cross-sectional area of the flow path, $\mathrm{cm}^{2}$

$=1.27 \mathrm{~cm}^{2}$ (from the area of a 0.5 -inch diameter hole.)

$\mathrm{D}=$ diffusivity of hydrogen in air, $\mathrm{cm}^{2} / \mathrm{s}$

$=0.75 \mathrm{~cm}^{2} / \mathrm{s}$.

The diffusivity of hydrogen through the gaps in the sonotube cushion is found from:

$$
\frac{1}{\mathrm{R} * 24.45 \mathrm{~L} / \mathrm{mole}} \text { or } \frac{1}{(667 \mathrm{~s} / \mathrm{L}) *(24.45 \mathrm{~L} / \text { mole })}=6.12 \times 10^{-5} \frac{\text { moles }}{\mathrm{s}-\text { mole fraction }}
$$

The diffusivity is proportional to the inverse of the resistance. To obtain the resistance for the three parallel paths, the effective resistance is found from:

$$
\begin{gathered}
\frac{1}{R_{e q}}=\frac{3}{R_{\text {hole }}} \\
\text { or } \\
\text { Diffusivity }_{\text {equivalent }}=3 * \text { Diffusivity }_{\text {hole }}
\end{gathered}
$$

As a result, the total diffusivity out of the three holes (one of the 4 holes is blocked) in the sonotube is $1.84 \times 10^{-4}$ moles/s-mole fraction (from 3 times $6.12 \times 10^{-5}$ ).

\section{Hydrogen transport through the bag around the sonotube into the PTO}

Section 6.2.2 provides data for hydrogen diffusion through the bag surface and through the horsetail in the sonotube bag. For this case, a NucFil-036-A bag filter is placed on the sonotube bag. Diffusion is primarily through the bag filter.

The diffusivity of the bag filter is $1.1 \times 10^{-4}$ moles/s-mole fraction (from manufacturer's datasheet found in HNF-16166, Appendix A, pg. A-11). The calculated diffusion through the bag surface and through the twist and tape closure is ignored, as it is small compared to the diffusivity of the bag filter. 


\section{$\underline{\mathbf{G}\left(\mathbf{H}_{2}\right.} \underline{2}$}

The value of $\mathrm{G}\left(\mathrm{H}_{2}\right)$ from Section 3.2 of 1.6 is used in this analysis. Section 3.2 provided arguments that this value bounds the G-values for solidified aqueous or homogeneous inorganic solids (Waste Material Type I) and high wattage solid organic materials with absorbed liquids (Waste Material Type III.1). This value is larger than the value of 1.09 used in Section 6.2.2.

\section{Summary of the Diffusion through the PTO in an SWB waste package - SWBs Shipped in the Future with a Bag Filter in the Sonotube Bag and with Hole in the Sonotube Cushion}

The result of the analysis is shown in Tables 6-6. The diffusivities are input (or calculated and then input) along with the other data necessary to solve the equations. The isotopic distribution from Section 3.1 The value of $\mathrm{G}\left(\mathrm{H}_{2}\right)$ is 1.6 from Section 3.2. The inventory is varied such that the hydrogen concentration in the sonotube bag is 4.8 percent (to be conservative relative to the 5 percent limit).

Table 6-5. Diffusion through the PTO in an SWB waste package - SWBs Shipped in the Future with a Bag Filter in the Sonotube Bag and with Holes in the Sonotube

\begin{tabular}{|c|c|c|}
\hline Path & Input Diffusivity & \\
\hline $\begin{array}{l}\text { From inside } \\
\text { sonotube to } \\
\text { outside sonotube } \\
\text { (Cell D15) }\end{array}$ & $\begin{array}{l}1.13 \mathrm{E}-4 \\
\text { (based on a } 2.25 \text {-inch opening, that is } 2.75 \text { inches } \\
\text { long [representing a fully threaded, schedule } 80 \text {, } \\
2.5 \text {-inch PVC pipe nipple], in the sonotube } \\
\text { cushion) }\end{array}$ & $\begin{array}{l}1.84 \mathrm{E}-4 \\
\text { (based on three open } 0.5 \text {-inch diameter } \\
\text { holes in the } 0.25 \text {-inch thick sonotube wall) }\end{array}$ \\
\hline $\begin{array}{l}\text { From outside } \\
\text { sonotube, through } \\
\text { sonotube bag to } \\
\text { inside PTO } \\
\text { (Cell E15) }\end{array}$ & $\begin{array}{l}1.1 \mathrm{E}-4 \\
\text { (NucFil-036-A Bag filter) }\end{array}$ & $\begin{array}{l}\text { 1.1E-4 } \\
\text { (NucFil-036-A Bag filter) }\end{array}$ \\
\hline $\begin{array}{l}\text { From inside PTO } \\
\text { to outside PTO } \\
\text { (Cell F15) }\end{array}$ & $\begin{array}{l}1.1 \mathrm{E}-5 \\
\text { (NucFil-013 filter) }\end{array}$ & $\begin{array}{l}1.1 \mathrm{E}-5 \\
\text { (NucFil-013 filter) }\end{array}$ \\
\hline $\begin{array}{l}\text { From outside PTO } \\
\text { to outside SWB } \\
\text { liner } \\
\text { (Cell G15) }\end{array}$ & $\begin{array}{l}1.0 \\
\text { (No liner) }\end{array}$ & $\begin{array}{l}1.0 \\
\text { (No liner) }\end{array}$ \\
\hline $\begin{array}{l}\text { From outside } \\
\text { SWB liner to } \\
\text { outside SWB } \\
\text { (Cell H15) }\end{array}$ & $\begin{array}{l}\text { 3.7E-5 } \\
\text { (Two NucFil-019DS filters) }\end{array}$ & $\begin{array}{l}3.7 \mathrm{E}-5 \\
\text { (Two NucFil-019DS filters) }\end{array}$ \\
\hline $\begin{array}{l}\text { Number of PTOs } \\
\text { in the SWB } \\
\text { (Cell D16) }\end{array}$ & Grams of Pu in each PTO* & \\
\hline 6 & 166 grams per PTO & 168 grams per $\mathrm{PTO}$ \\
\hline 3 & 237 grams per PTO & 241 grams per PTO \\
\hline
\end{tabular}


Table 6-5. Diffusion through the PTO in an SWB waste package - SWBs Shipped in the Future with a Bag Filter in the Sonotube Bag and with Holes in the Sonotube

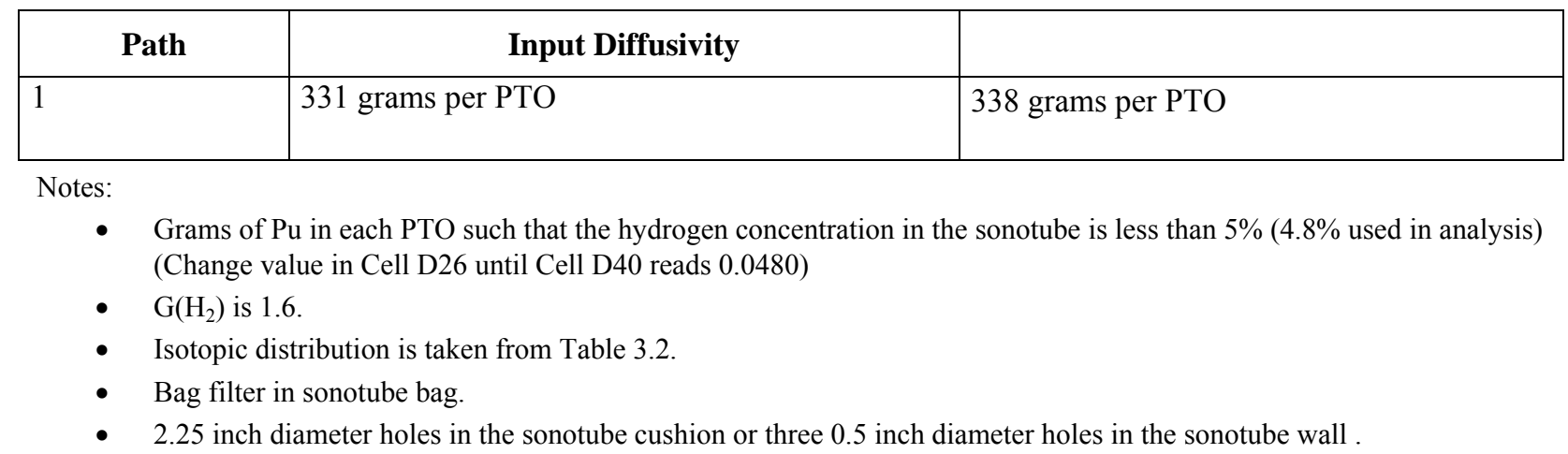

For comparison, SWBs packaged for shipment to WIPP are packaged at best estimate value plus twice the total measurement uncertainty (TMU) not to exceed 325 grams. The TMU of $30 \%$ is a basis of the Criticality Safety Evaluation Report for Hanford waste drums (HNF-33183, CSER 07-004, Storage and Handling of Waste Drums in the Solid Waste Operations Complex) which is also applied to PTOs in SWBs. Twice that amount is $60 \%$. A best estimate inventory of $203 \mathrm{~g}$ is equal to a "best estimate plus two TMU of $325 \mathrm{~g}$. As a result, the allowable inventories shown in Table 6-5 exceed what is allowed to be shipped.

\subsection{Miscellaneous Calculations}

\section{Relating the TRUCON Code Description to the Resistance of the Pathway}

Rev. 48 of CH-TRUCON (DOE/WIPP-0103194) shows the following for the PTO Package (RH 111S/112S):

"Size-reduced sections of pencil tank waste are placed inside a cardboard tube. The cardboard tube is packaged in a twist-and-taped drum liner bag, which is then placed in a PVC pipe with caps at each end. The PVC pipe is vented with a filter with a minimum diffusivity of 3.7E-06 moles/s-mole fraction. Up to six "pencil tank overpacks" are packaged in a direct-load SWB. The SWB is vented such that it has a minimum total hydrogen diffusivity of 3.7E-05 moles/s-mole fraction."

Based on the TRUCON Code:

- The bag around the sonotube can be represented by a large drum liner bag (diffusivity of 4.67E-6 moles/s-mole fraction (See page D-2 of Appendix D of this report).

- The filter in the PTO must have a diffusivity of no smaller than 3.7E-6 moles/s-mole fraction

- The SWB contains filters such that the minimum diffusivity is equal to or greater than 3.7E-5 moles/s-mole fraction. 
The TRUCON Code is silent on the cushion in the sonotube. However, in a discussion with WIPP personnel, the resistance to diffusion flow out of the sonotube was considered to be negligible.

The resistance of the pathway from inside the sonotube to outside of the SWB can be determined using the shipping category. Appendix G, of this report, shows that the numeric designation of the shipping category for the PTO in an SWB is 1001600077 . Section 2.2 of the CH TRU Payload Appendices show that the numeric designation (XX YYYY ZZZZ) consists of three parts. The first designator $(\mathrm{XX})$ is the waste type. The waste type does not enter into the calculations. The second designator $(\mathrm{XXXX})$ is the value of $\mathrm{G}\left(\mathrm{H}_{2}\right)$ times 100 . In this case, the value of $\mathrm{G}\left(\mathrm{H}_{2}\right)$ is 1.6. Multiplying yields 160 or, in four-digit format, 0160 . A value of $\mathrm{G}\left(\mathrm{H}_{2}\right)$ of 1.6 is used in the analysis. The last designator is the resistance. Page 2.1-1 of the CH TRU Payload Appendices says that this designator (ZZZZ) is the resistance to hydrogen release multiplied by $1 \mathrm{E}-4$. Since $\mathrm{Z}$ is 0077 , the resistance is $0077 / 1 \mathrm{E}-4$ or $7.7 \mathrm{E} 5 \mathrm{~s} / \mathrm{mole}$.

The total resistance for the PTO/SWB package is found as follows:

$$
R=\left[\left(\frac{1}{D_{\text {sonotube }}}+\frac{1}{D_{\text {sonotube bag }}}+\frac{1}{D_{\text {PTO filter }}}\right) * \frac{1}{N_{\text {PTOS }}}\right]+\frac{1}{D_{\text {Liner }}}+\frac{1}{D_{S W B}}
$$

where:

$$
\begin{aligned}
& \mathrm{R}=\text { resistance, } \mathrm{sec} / \mathrm{mole} \\
& \mathrm{D}_{\mathrm{X}} \quad=\text { diffusivity of path "X," moles/s-mole fraction } \\
& \mathrm{D}_{\text {sonotube }}=\text { not considered as the sonotube is assumed to have negligible resistance } \\
& \text { to hydrogen diffusion } \\
& \mathrm{D}_{\text {sonotube bag }}=4.67 \times 10^{-6} \mathrm{moles} / \mathrm{s}-\mathrm{mole} \text { fraction (from Appendix D) } \\
& \mathrm{D}_{\text {PTO flilter }}=3.7 \times 10^{-6} \mathrm{moles} / \mathrm{s}-\mathrm{mole} \text { fraction per the TRUCON code } \\
& \mathrm{D}_{\text {Liner }}=\text { not considered as there is no liner } \\
& \mathrm{D}_{\mathrm{SWB}}=3.7 \times 10^{-5} \mathrm{moles} / \mathrm{s}-\mathrm{mole} \text { fraction per TRUCON code } \\
& \mathrm{N}=\text { number of PTOs in the SWB. }
\end{aligned}
$$

The summary tables above show that the case with the most restrictive SWB inventory is the case where there is only one PTO. For this analysis, $\mathrm{N}_{\mathrm{PTO}}=1.0$. Given this, " $\mathrm{R}$ " is $5.1 \times 10^{5}$ sec/mole.

However, Section 2.2.4, Table 2.2-4 of the CH-TRU Payload Appendices shows that there is one additional resistance to consider. That is the "resistance" due to a shipping window of 60 days. This resistance is a way to account for the increase in hydrogen concentration during shipping, during which time the waste package (in this case, the SWB containing PTOs) is overpacked. For direct-loaded SWBs, the resistance factor is 1,430. Section 2.2.1 states that the resistance factor is equal to the resistance divided by 100 . Therefore, if the resistance factor is 1,430 , the resistance is 143,000 . Adding this resistance to the resistance of the sonotube bag and filters 
yields a total resistance of $6.5 \times 10^{5} \mathrm{sec} /$ mole. This is close to the shipping category value of $7.7 \times 10^{5} \mathrm{sec} / \mathrm{mole}$.

The total resistance can also be obtained by using Section 2.2 of the $\mathrm{CH}$-TRU Payload Appendices. Table 6-7 shows the resistances from the CH-TRU Payload Appendices for the individual components of the PTO. The resistance can be obtained using the equation above.

Table 6-7. Resistance factors for various components of the PTO in an SWB

\begin{tabular}{|l|l|l|l|}
\hline \multicolumn{1}{|c|}{ Item } & $\begin{array}{c}\text { Table from Section 2.2 of } \\
\text { the } \mathbf{C H} \text {-TRU Payload } \\
\text { Appendices that provides } \\
\text { the resistance factor }\end{array}$ & $\begin{array}{c}\text { Resistance factor (using } \\
\text { Column 1) }\end{array}$ & Resistance, sec/mole \\
\hline $\begin{array}{l}\text { Twist and Tape Drum } \\
\text { Liner Bag } \\
\text { (represents the sonotube } \\
\text { bag) }\end{array}$ & Table 2.2-1 & 2,142 & 214,200 \\
\hline $\begin{array}{l}\text { Pipe Overpack or 55-gallon } \\
\text { drum filter (represents PTO } \\
\text { filter) }\end{array}$ & Table 2.2-3 & 3,746 & 374,600 \\
\hline $\begin{array}{l}\text { Direct Load SWB filter } \\
\text { (Represents one of the } \\
\text { SWB filters. The value is } \\
\text { halved for two filters) }\end{array}$ & Table 2.2-3 & 375 (from 750/2) & 37,500 \\
\hline $\begin{array}{l}\text { Load Resistance based on } \\
\text { 60-day shipping window } \\
\text { for direct-load SWB }\end{array}$ & Table 2.2-4 & 1,430 & 143,000 \\
\hline Total Resistance & & $\mathbf{7 7 0 , 0 0 0}$ \\
\hline
\end{tabular}

The value of $7.7 \times 10^{5} \mathrm{~s} /$ mole equals that in the TRUCON code.

\section{Decay Heat}

The resistance, calculated above, can be used to determine the allowable decay heat for the SWB. The decay heat can be obtained in two ways. First, data from the spreadsheet, used to obtain the hydrogen concentration within the sonotube, can be used to determine the associated decay heat. The equation for decay heat is:

$$
\text { Decay heat per PTO }=(\text { grams Pu }) *\left(\frac{C i}{g}\right) * \frac{3.7 \times 10^{10} \mathrm{dis}}{C i} * \frac{\mathrm{Mev}}{\mathrm{dis}} * \frac{10^{6} \mathrm{ev}}{\mathrm{Mev}} * \frac{1.6 E-19 \mathrm{~W}}{\mathrm{ev}}
$$


where:

$$
\begin{array}{ll}
\text { Grams Pu } & =\text { inventory in the PTO } \\
\mathrm{Ci} / \mathrm{g} & =\text { curies per gram of Pu (alpha emitters) (Column } 4 \text { of Table 3-2) } \\
\text { Mev/dis } & =\text { energy released per disintegration (Column } 5 \text { of Table 3-2). }
\end{array}
$$

The calculation uses the value of "Ci/g" for the isotopic mixture and the average energy release for those isotopes.

The other way is to use Page 2.3-5 of the CH TRU Payload appendices. Equation 7 shows a way to find the decay heat rate;

$$
Q=\frac{0.05 * 6.023 \times 10^{23} \frac{\text { molecules }}{\text { mole }} * 1.602 \times 10^{-19} \frac{\mathrm{watt}}{\mathrm{ev}}}{\left.R_{T} *(G / 100)\right)}
$$

where:

$$
\begin{aligned}
& \mathrm{Q}=\text { decay heat, Watts } \\
& 0.05=5 \text { percent hydrogen, the allowable concentration } \\
& \mathrm{R}_{\mathrm{T}}=\text { Total Resistance, } \mathrm{s} / \text { mole } \\
& \mathrm{G} \quad=\text { value of } \mathrm{G}\left(\mathrm{H}_{2}\right)=1.6 \text { in this case. }
\end{aligned}
$$




\subsection{References}

2Z-10-0184-045-00, 2010, Work Package Engineering 45 of PFP Work Document Number 2Z10-0184, Cut Up and Dispose PRF Pencil Tank Assemblies

BNWL-751, 1968, Alpha Radiolysis of Plutonium (IV) - Nitric Acid Solutions, Battelle Pacific Northwest Laboratories, Richland, Washington.

CH-TRU Payload Appendices, 2009, Rev. 2, Waste Isolation Pilot Plant, Carlsbad, New Mexico. (Rev. 1, 2004 is found at http://pbadupws.nrc.gov/docs/ML0430/ML043000139.pdf)

DOE/WIPP 01-3194, 2011, CH-TRU Waste Content Codes(CH-TRUCON), Rev. 43, U. S. Department of Energy, Carlsbad, New Mexico.

Drawing H-2-836485, 2013, Pencil Tank Overpack Assemblies, CH2M HILL Plateau Remediation Company, Richland, Washington.

Drawing 165-F-001-W1, 1989, Standard Waste Box Assembly, Washington TRU Solutions, LLC, Waste Isolation Pilot Program, U. S. Department of Energy, Carlsbad, New Mexico.

EPA-600/2-79-038, 1979, Liner Materials Exposed to Municipal Solid Waste Leachate - Third Interim Report, Municipal environmental Research Laboratory, US Environmental Protection Agency, Cincinnati, Ohio. http://nepis.epa.gov/Exe/ZyNET.exe/20006DSF.TXT?ZyActionD=ZyDocument\&Client $=$ EPA\&Index $=1976+$ Thru $+1980 \&$ Docs $=\&$ Query $=\&$ Time $=\&$ EndTime $=\&$ SearchMethod $=1 \&$ TocRestrict $=$ n $\&$ Toc $=\&$ TocEntry $=\& Q$ field $=\& Q$ field Year $=\& Q$ fieldMonth $=\& Q$ fieldD ay $=\&$ IntQFieldO $p=0 \&$ ExtQFieldO $p=0 \& X m l Q u e r y=\& F i l e=D \% 3 \mathrm{~A} \% 5$ Czyfiles $\% 5$ Cindex \%20Data \%5C76thru80\%5CTxt\%5C00000001\%5C20006DSF.txt\&User=ANONYMOU S\&Password $=$ anonymous \&SortMethod $=\mathrm{h} \% 7 \mathrm{C}-$

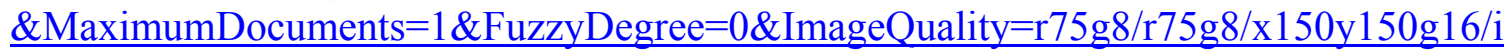
425\&Display $=\mathrm{p} \%$ 7Cf\&DefSeekPage $=\mathrm{x} \&$ SearchBack $=$ ZyActionL\&Back $=$ ZyActionS\&B $\underline{\text { ackDesc }=\text { Results } \% 20 \text { page \&MaximumPages }=1 \& \text { ZyEntry }=1 \& \text { SeekPage }=x \& Z y P U R L}$

HNF-15500, 2013, Plutonium Finishing Plant Deactivation and Decommissioning Documented Safety Analysis, Rev 8, CH2M HILL Plateau Remediation Company, Richland, Washington.

HNF-16166, 2006, Required Staging Times for Hydrogen diffusion in Vented Waste Containers, Rev. 7, Fluor Hanford, Inc., Richland, Washington.

HNF-26181, 2005, User's Guide and Model Description for RADIDOSE Version 3.0, Fluor Hanford, Inc., Richland, Washington.

HNF-EP-0063, 2011, Hanford Site Solid Waste Acceptance Criteria, Rev 16, CH2M HILL Plateau Remediation Company, Richland, Washington.

ICP/CON-04-00563, 2005, High Hydrogen Concentrations Detected In The Underground Vaults For RH-TRU Waste At INEEL Compared With Calculated Values Using The INEELDeveloped Computer Code, Idaho completion Project, Bechtel BWXT Idaho, LLC, Idaho Falls, Idaho. Found at: http://www.inl.gov/technicalpublications/Documents/3169740.pdf 
CHPRC-01674, Rev. 1

LA-12846-MS, 1994, Specific Activities and DOE-STD-1027-92 Hazard Category 2 Thresholds - LANL Fact Sheet, Los Alamos National Laboratory, Los Alamos, New Mexico.

LA-UR-03-6520, 2003, The General's Tanks Characterization Activities Documented Safety Analysis, Los Alamos National Laboratory, Los Alamos, New Mexico. Found at: http://www.doeal.gov/SWEIS/LANLDocuments/243\%20The\%20General's\%20Tanks\%2 0Characterization $\% 20$ Activities $\% 20$ Documented $\% 20$ Safety $\% 20$ Analysis.pdf

NUREG/CR-6673, 2000, Hydrogen Generation in TRU Waste Transportation Packages, Lawrence Livermore National Laboratories, Livermore, CA. Found at: http://pbadupws.nrc.gov/docs/ML0037/ML003723404.pdf

Parker O-Ring Handbook, 2007, ORD 5700, Parker Hannifin Corporation, Lexington, Kentucky. Found at: http://www.parker.com/literature/ORD\%205700\%20Parker_ORing Handbook.pdf

PB-230 846, 1970, Radiological Health Handbook, US Department of Health, Education and Welfare, Bureau of Radiological Health, Rockville, Maryland.

SAND2006-1163, 2006, Technical Reference on Hydrogen Compatibility of Material, Chapter 8100, "Polymers of the reference Technical Reference on Hydrogen Compatibility of Materials," Sandia National Laboratory, Albuquerque, New Mexico. http://www.sandia.gov/matlsTechRef/chapters/8100TechRef_polymers.pdf

ZSP-003, 2011, Seal-Out from Glovebox or Glovebag or Remove Items from Hoods, Rev. 5, Change 1, Plutonium Finishing Plant Standard Practices and Procedures, CH2M HILL Plateau Remediation Company, Richland, Washington. 


\section{Appendix A}

Details of the Steps Involved to Calculate the Hydrogen Concentration in the Sonotube using Steady State Diffusion Equations for the Pencil Tank Overpack 


\section{Appendix A \\ Details of the Steps Involved to Calculate the Hydrogen Concentration in the Sonotube using Steady State Diffusion Equations for the Pencil Tank Overpack}

Hydrogen flow path:

- From Sonotube (S) to bag around sonotube (BAS)

- From BAS to PTO

- From up to 6 PTOs to SWB Liner

- From SWB Liner to SWB

- From SWB to atmosphere

Subscripts:

$\mathrm{S}$

BAS

PTO

SWB

SWBL

$\mathrm{H} 2$

$\mathrm{T}$

Variables:

$\mathrm{n}_{\mathrm{A}} \quad$ number of moles in Enclosure A

$\mathrm{L}_{\mathrm{R}, \mathrm{A} \rightarrow(\mathrm{B})} \quad$ Diffusivity (hydrogen removal) from Enclosure A to Enclosure B

$\mathrm{n}_{\mathrm{H} 2, \mathrm{Gen}}$

$\mathrm{N}_{\text {PTO }}$
Sonotube

Bag around sonotube

Pencil Tank Overpack (PTO)

Standard Waste Box (SWB)

SWB Liner

hydrogen

total (hydrogen + air)

A. Hydrogen in the sonotube (hydrogen generation in the sonotube minus flow out of sonotube to bag around sonotube):

$$
\mathrm{n}_{\mathrm{H} 2, \mathrm{Gen}}=\mathrm{L}_{\mathrm{R}, \mathrm{S} \rightarrow \mathrm{BAS}}\left(\frac{\mathrm{n}_{\mathrm{H} 2, \mathrm{~S}}}{\mathrm{n}_{\mathrm{T}, \mathrm{S}}}-\frac{\mathrm{n}_{\mathrm{H} 2, \mathrm{BAS}}}{\mathrm{n}_{\mathrm{T}, \mathrm{BAS}}}\right)
$$


B. Hydrogen in the bag around the sonotube (flow from the sonotube into the bag and flow out of the bag into the PTO):

$$
\left\{\left(\mathrm{L}_{\mathrm{R},(\mathrm{S}) \rightarrow \mathrm{BAS}}\right)\left(\frac{\mathrm{n}_{\mathrm{H} 2,(\mathrm{~S})}}{\mathrm{n}_{\mathrm{T},(\mathrm{S})}}-\frac{\mathrm{n}_{\mathrm{H} 2, \mathrm{BAS}}}{\mathrm{n}_{\mathrm{T}, \mathrm{BAS}}}\right)\right\}=\left\{\left(\mathrm{L}_{\mathrm{R}, \mathrm{BAS} \rightarrow(\mathrm{PTO})}\right)\left(\frac{\mathrm{n}_{\mathrm{H} 2, \mathrm{BAS}}}{\mathrm{n}_{\mathrm{T}, \mathrm{BAS}}}-\frac{\mathrm{n}_{\mathrm{H} 2,(\mathrm{PTO})}}{\mathrm{n}_{\mathrm{T},(\mathrm{PTO})}}\right)\right\}
$$

C. Hydrogen in the PTO (flow from the bag into the PTO and flow out of the PTO into the SWBL):

$\left\{\left(\mathrm{L}_{\mathrm{R},(\mathrm{BAS}) \rightarrow \mathrm{PTO}}\right)\left(\frac{\mathrm{n}_{\mathrm{H} 2, \mathrm{BAS}}}{\mathrm{n}_{\mathrm{T},(\mathrm{BAS})}}-\frac{\mathrm{n}_{\mathrm{H} 2, \mathrm{PTO}}}{\mathrm{n}_{\mathrm{T}, \mathrm{PTO}}}\right)\right\}=\left\{\left(\mathrm{L}_{\mathrm{R}, \mathrm{PTO} \rightarrow(\mathrm{SWBL})}\right)\left(\frac{\mathrm{n}_{\mathrm{H} 2, \mathrm{PTO}}}{\mathrm{n}_{\mathrm{T}, \mathrm{PTO}}}-\frac{\mathrm{n}_{\mathrm{H} 2,(\mathrm{SWBL})}}{\mathrm{n}_{\mathrm{T},(\mathrm{SWBL})}}\right)\right\}$

D. Hydrogen in the SWBL (flow from the PTO into the SWBL and flow out of the SWBL into the SWB):

$\mathrm{N}_{\mathrm{PTO}}\left\{\left(\mathrm{L}_{\mathrm{R},(\mathrm{PTO}) \rightarrow \mathrm{SWBL}}\right)\left(\frac{\mathrm{n}_{\mathrm{H} 2,(\mathrm{PTO})}}{\mathrm{n}_{\mathrm{T},(\mathrm{PTO})}}-\frac{\mathrm{n}_{\mathrm{H} 2, \mathrm{SWBL}}}{\mathrm{n}_{\mathrm{T}, \mathrm{SWBL}}}\right)\right\}=\left\{\left(\mathrm{L}_{\mathrm{R}, \mathrm{SWBL} \rightarrow(\mathrm{SWB})}\right)\left(\frac{\mathrm{n}_{\mathrm{H} 2, \mathrm{SWBL}}}{\mathrm{n}_{\mathrm{T}, \mathrm{SWBL}}}-\frac{\mathrm{n}_{\mathrm{H} 2,(\mathrm{SWB})}}{\mathrm{n}_{\mathrm{T},(\mathrm{SWB})}}\right)\right\}$

or

$\left\{\left(\mathrm{L}_{\mathrm{R},(\mathrm{PTO}) \rightarrow \mathrm{SWBL}}\right)\left(\frac{\mathrm{n}_{\mathrm{H} 2,(\mathrm{PTO})}}{\mathrm{n}_{\mathrm{T},(\mathrm{PTO})}}-\frac{\mathrm{n}_{\mathrm{H} 2, \mathrm{SWBL}}}{\mathrm{n}_{\mathrm{T}, \mathrm{SWBL}}}\right)\right\}=\frac{1}{\mathrm{~N}_{\mathrm{PTO}}}\left(\mathrm{L}_{\mathrm{R}, \mathrm{SWBL} \rightarrow(\mathrm{SWB})}\right)\left(\frac{\mathrm{n}_{\mathrm{H} 2, \mathrm{SWBL}}}{\mathrm{n}_{\mathrm{T}, \mathrm{SWBL}}}-\frac{\mathrm{n}_{\mathrm{H} 2,(\mathrm{SWB})}}{\mathrm{n}_{\mathrm{T},(\mathrm{SWB})}}\right)$

E. Hydrogen in the SWB (Flow from the SWBL into the SWB and flow out of the SWB to the atmosphere):

$\left\{\left(\mathrm{L}_{\mathrm{R},(\mathrm{SWBL}) \rightarrow \mathrm{SWB}}\right)\left(\frac{\mathrm{n}_{\mathrm{H} 2,(\mathrm{SWBL})}}{\mathrm{n}_{\mathrm{T},(\mathrm{SWBL})}}-\frac{\mathrm{n}_{\mathrm{H} 2, \mathrm{SWB}}}{\mathrm{n}_{\mathrm{T}, \mathrm{SWB}}}\right)\right\}=\left\{\left(\mathrm{L}_{\mathrm{R}, \mathrm{SWB} \rightarrow \text { atmos }}\right)\left(\frac{\mathrm{n}_{\mathrm{H} 2, \mathrm{SWB}}}{\mathrm{n}_{\mathrm{T}, \mathrm{SWB}}}-\frac{\mathrm{n}_{\mathrm{H} 2, \mathrm{atmos}}}{\mathrm{n}_{\mathrm{T}, \text { atmos }}}\right)\right\}$

(Eq. 5) 


\section{Method of solution:}

$\underline{\text { Step } 1}$

Add Equations 1-3. This yields Equation 6:

$$
\mathrm{n}_{\mathrm{H} 2, \mathrm{Gen}}=\left\{\left(\mathrm{L}_{\mathrm{R}, \mathrm{PTO} \rightarrow(\mathrm{SWBL})}\right)\left(\frac{\mathrm{n}_{\mathrm{H} 2, \mathrm{PTO}}}{\mathrm{n}_{\mathrm{T}, \mathrm{PTO}}}-\frac{\mathrm{n}_{\mathrm{H} 2,(\mathrm{SWBL})}}{\mathrm{n}_{\mathrm{T},(\mathrm{SWBL})}}\right)\right\}
$$

Step 2

Add Equation 6 to Equation 4b. This yields Equation 7a and Equation 7b:

$$
\begin{gathered}
\mathrm{n}_{\mathrm{H} 2, \mathrm{Gen}}=\frac{1}{\mathrm{~N}_{\mathrm{PTO}}}\left(\mathrm{L}_{\mathrm{R}, \mathrm{SWBL} \rightarrow(\mathrm{SWB})}\right)\left(\frac{\mathrm{n}_{\mathrm{H} 2, \mathrm{SWBL}}}{\mathrm{n}_{\mathrm{T}, \mathrm{SWBL}}}-\frac{\mathrm{n}_{\mathrm{H} 2,(\mathrm{SWB})}}{\mathrm{n}_{\mathrm{T},(\mathrm{SWB})}}\right) \\
\text { or } \\
\mathrm{n}_{\mathrm{H} 2, \mathrm{Gen}} * \mathrm{~N}_{\mathrm{PTO}}=\left(\mathrm{L}_{\mathrm{R}, \mathrm{SWBL} \rightarrow(\mathrm{SWB})}\right)\left(\frac{\mathrm{n}_{\mathrm{H} 2, \mathrm{SWBL}}}{\mathrm{n}_{\mathrm{T}, \mathrm{SWBL}}}-\frac{\mathrm{n}_{\mathrm{H} 2,(\mathrm{SWB})}}{\mathrm{n}_{\mathrm{T},(\mathrm{SWB})}}\right)
\end{gathered}
$$

Step 3

Add Equation $7 \mathrm{~b}$ and Equation 5. This yields Equation 8, the mole fraction of hydrogen in the SWB (since $\frac{\mathrm{n}_{\mathrm{H} 2 \text {,atmos }}}{\mathrm{n}_{\mathrm{T}, \text { atmos }}}=0.0$ ):

$$
\mathrm{n}_{\mathrm{H} 2, \mathrm{Gen}} * \mathrm{~N}_{\mathrm{PTO}}=\left\{\left(\mathrm{L}_{\mathrm{R}, \mathrm{SWB} \rightarrow \mathrm{atmos}}\right)\left(\frac{\mathrm{n}_{\mathrm{H} 2, \mathrm{SWB}}}{\mathrm{n}_{\mathrm{T}, \mathrm{SWB}}}-\frac{\mathrm{n}_{\mathrm{H} 2, \mathrm{atmos}}}{\mathrm{n}_{\mathrm{T}, \mathrm{atmos}}}\right)\right\}
$$

\section{$\underline{\text { Step } 4}$}

Equation 8 is solved for the mole fraction in the SWB.

$$
\frac{\mathrm{n}_{\mathrm{H} 2, \mathrm{Gen}} * \mathrm{~N}_{\mathrm{PTO}}}{\mathrm{L}_{\mathrm{R}, \mathrm{SWB} \rightarrow \text { atmos }}}=\frac{\mathrm{n}_{\mathrm{H} 2, \mathrm{SWB}}}{\mathrm{n}_{\mathrm{T}, \mathrm{SWB}}}
$$




\section{$\underline{\text { Step } 5}$}

The value obtained for the mole fraction in the SWB is used in Equation $7 b$ to obtain the mole fraction in the SWB Liner.

$$
\frac{\mathrm{n}_{\mathrm{H} 2, \mathrm{Gen}} * \mathrm{~N}_{\mathrm{PTO}}}{\mathrm{L}_{\mathrm{R}, \mathrm{SWBL} \rightarrow(\mathrm{SWB})}}+\frac{\mathrm{n}_{\mathrm{H} 2,(\mathrm{SWB})}}{\mathrm{n}_{\mathrm{T},(\mathrm{SWB})}}=\left(\frac{\mathrm{n}_{\mathrm{H} 2, \mathrm{SWBL}}}{\mathrm{n}_{\mathrm{T}, \mathrm{SWBL}}}\right)
$$

\section{$\underline{\text { Step } 6}$}

The value obtained for the mole fraction in the SWBL is used in Equation 6 to obtain the mole fraction in the PTO.

$$
\frac{\mathrm{n}_{\mathrm{H} 2, \mathrm{Gen}}}{\mathrm{L}_{\mathrm{R}, \mathrm{PTO} \rightarrow(\mathrm{SWBL})}}+\frac{\mathrm{n}_{\mathrm{H} 2,(\mathrm{SWBL})}}{\mathrm{n}_{\mathrm{T},(\mathrm{SWBL})}}=\frac{\mathrm{n}_{\mathrm{H} 2, \mathrm{PTO}}}{\mathrm{n}_{\mathrm{T}, \mathrm{PTO}}}
$$

\section{$\underline{\text { Step } 7}$}

The value obtained for the mole fraction in the PTO is used in Equation 3 to obtain the mole fraction in the bag around the sonotube.

$$
\frac{\mathrm{n}_{\mathrm{H} 2, \mathrm{BAS}}}{\mathrm{n}_{\mathrm{T},(\mathrm{BAS})}}=\frac{\mathrm{n}_{\mathrm{H} 2, \mathrm{PTO}}}{\mathrm{n}_{\mathrm{T}, \mathrm{PTO}}}+\left\{\left(\frac{\mathrm{L}_{\mathrm{R}, \mathrm{PTO} \rightarrow(\mathrm{SWBL})}}{\mathrm{L}_{\mathrm{R},(\mathrm{BAS}) \rightarrow \mathrm{PTO}}}\right)\left(\frac{\mathrm{n}_{\mathrm{H} 2, \mathrm{PTO}}}{\mathrm{n}_{\mathrm{T}, \mathrm{PTO}}}-\frac{\mathrm{n}_{\mathrm{H} 2,(\mathrm{SWBL})}}{\mathrm{n}_{\mathrm{T},(\mathrm{SWBL})}}\right)\right\}
$$

\section{$\underline{\text { Step } 8}$}

The value obtained for the mole fraction in the bag around the sonotube is used in Equation 2 to obtain the mole fraction in the sonotube.

$$
\frac{\mathrm{n}_{\mathrm{H} 2,(\mathrm{~S})}}{\mathrm{n}_{\mathrm{T},(\mathrm{S})}}=\frac{\mathrm{n}_{\mathrm{H} 2, \mathrm{BAS}}}{\mathrm{n}_{\mathrm{T}, \mathrm{BAS}}}+\left\{\left(\frac{\mathrm{L}_{\mathrm{R}, \mathrm{BAS} \rightarrow(\mathrm{PTO})}}{\mathrm{L}_{\mathrm{R},(\mathrm{S}) \rightarrow \mathrm{BAS}}}\right)\left(\frac{\mathrm{n}_{\mathrm{H} 2, \mathrm{BAS}}}{\mathrm{n}_{\mathrm{T}, \mathrm{BAS}}}-\frac{\mathrm{n}_{\mathrm{H} 2,(\mathrm{PTO})}}{\mathrm{n}_{\mathrm{T},(\mathrm{PTO})}}\right)\right\}
$$


CHPRC-01674, Rev. 1

\section{Appendix B}

\section{Literature Search for Values for Permeability of Plastics}




\section{Appendix B Literature Search for Values for Permeability of Plastics}

A literature search was performed to determine the permeability of PVC and other plastics for use in determining the hydrogen concentration in waste packages. The results are shown below. SAND2006-1163, Technical Reference on Hydrogen Compatibility of Material, Chapter 8100, "Polymers of the Technical Reference on Hydrogen Compatibility of Materials," states the permeability of gases through polymers is assumed to be independent of pressure and is defined as:

$$
\mathrm{P}=\mathrm{DS}
$$

where:

$$
\begin{array}{lll}
\mathrm{P} & = & \text { permeability, moles } \mathrm{H}_{2} / \mathrm{m}-\mathrm{s}-\mathrm{MPa} \text { or } \mathrm{cm}^{3}-\mathrm{cm} / \mathrm{s}-\mathrm{cm}^{2}-\mathrm{cmHg} \\
\mathrm{D} & = & \text { diffusivity, } \mathrm{m}^{2} / \mathrm{s} \text { or } \mathrm{cm}^{2} / \mathrm{s} \\
\mathrm{S} & = & \text { solubility, }\left(\mathrm{moles} / \mathrm{m}^{3}\right) / \mathrm{MPa} \text { or }\left(\mathrm{cm}^{3} \mathrm{H}_{2} / \mathrm{cm}^{3}\right) / \mathrm{cmHg} .
\end{array}
$$

In this section, the units are changed from those that are used in the various references to follow to $\frac{\mathrm{cm}^{3}-\mathrm{cm}}{\mathrm{s}-\mathrm{cm}^{2}-\mathrm{cmHg}}$. In most cases, the change involves a simple unit conversion. However, in some cases, the units are moles/s-mole fraction. In this case, moles can be related to $\mathrm{cm}^{3}$ using the ideal gas law at room temperature and pressure. The material area and thickness can be used to obtain the term "cm $/ \mathrm{cm}^{2}$ " portion of the term. The portion of the permeability term, "cmHg," can be obtained by noting that a mole fraction of 1.0 inside a container results in a pressure equal to atmospheric pressure. As a result, for purposes of unit conversion, 1 mole fraction $=76$ cmHg.

\section{B.1 The Paper: High Hydrogen Concentrations Detected in the Underground Vaults For RH-TRU Waste At INEEL Compared With Calculated Values Using The INEEL- Developed Computer Code}

Page 14 of ICP/CON-04-00563, High Hydrogen Concentrations Detected In The Underground Vaults for RH-TRU Waste at INEEL Compared with Calculated Values Using the INEELDeveloped Computer Code, used a value for permeability for a "polyethylene" bag of

$$
7.6 \times 10^{-10} \frac{\mathrm{cm}^{3}-\mathrm{cm}}{\mathrm{s}-\mathrm{cm}^{2}-\mathrm{kPa}} \text { or } 10.1 \times 10^{-10} \frac{\mathrm{cm}^{3}-\mathrm{cm}}{\mathrm{s}-\mathrm{cm}^{2}-\mathrm{cmHg}} \text { (using } 101 \mathrm{kPa}=76 \mathrm{cmHg} \text { ). }
$$




\section{B.2 The Paper: Measurement of Hydrogen Diffusion Rates Through Both "Twist And Tape" and Heat-Sealed Polyurethane And Polyvinyl Chloride Bags}

The paper provides diffusion rates through a layer of polyurethane (PU) and a layer of polyvinyl chloride (PVC). In the test, the PU and PVC layer (separately) are wrapped over the outlet of a 10-in. diameter pipe. The layer is wrapped over the top opening of the pipe. The sides of the layer are taped to the side of the pipe. There is extra material over the top of the pipe (i.e., the layer is not wrapped tightly across the pipe opening). The extra material makes the effective shape of the layer resemble a cylinder with no base. The layer is estimated to have a height of 1 in. The effective surface area of the layer is comprised of the area of the circular top of the layer (10 in. or $25.4 \mathrm{~cm}$ diameter for an area of $507 \mathrm{~cm}^{2}$ ) and the area of the sides of the cylinder (10 in. in diameter and $1 \mathrm{in}$. tall for an area of $203 \mathrm{~cm}^{2}$ ). The total area for diffusion is $710 \mathrm{~cm}^{2}$.

Table 2 of the paper Measurement of Hydrogen Diffusion Rates Through Both "Twist and Tape" and Heat-Sealed Polyurethane and Polyvinyl Chloride Bags, shows the following values of hydrogen diffusivity through polyurethane (PU) and polyvinyl chloride (PVC) bags with heatsealed ends, corrected to $25^{\circ} \mathrm{C}$ :

- $\quad 2.32 \times 10^{-7}$ Moles/s-mole-fraction for Polyurethane (PU) 6-mil thick PVC bag having an area of $0.17 \mathrm{ft}^{2}\left(710 \mathrm{~cm}^{2}\right)$ for a bag that is $10 \mathrm{in}$. in diameter and $1 \mathrm{in}$. tall (estimate) wrapped over a 10-in. diameter pipe.

- $\quad 1.71 \times 10^{-7}$ Moles/s-mole-fraction for a 14-mil thick PVC bag having an area of $0.71 \mathrm{ft}^{2}$ $\left(710 \mathrm{~cm}^{2}\right)$ for a bag that is $10 \mathrm{in}$. in diameter and $1 \mathrm{in}$. tall (estimate) wrapped over a 10 in diameter pipe.

Using the following conversion factors:

At $25^{\circ} \mathrm{C}(298 \mathrm{~K}), 1$ moles occupies $24,450 \mathrm{~cm}^{3}$ (using a value for the gas constant as $0.08206 \mathrm{~L}-\mathrm{atm} / \mathrm{mole}-\mathrm{K})$.

$$
14 \text { mil }=0.014 \text { in or } 0.0356 \mathrm{~cm} \text {. }
$$

1 mole frac $=76 \mathrm{cmHg}$.

The permeability of the PVC bag is:

$$
\begin{gathered}
\frac{1.71 \times 10^{-7} \text { moles }}{\mathrm{s}-\text { mole frac. }} * \frac{24,450 \mathrm{~cm}^{3}}{\text { mole }} * \frac{0.0356 \mathrm{~cm}}{710 \mathrm{~cm}^{2}} * \frac{\text { mole frac. }}{76 \mathrm{~cm} \mathrm{Hg}}= \\
28 \times 10^{-10} \frac{\mathrm{cm}^{3}}{\mathrm{~s}} \frac{\mathrm{cm}}{\mathrm{cm}^{2}-\mathrm{cmHg}}
\end{gathered}
$$

The permeability of the PU bag is found in the same way, except that the bag thickness is 6 mil, not 14 mil. The permeability of the PU bag is $16 \times 10^{-10} \mathrm{~cm}^{3}-\mathrm{cm} / \mathrm{s}-\mathrm{cm}^{2}-\mathrm{cmHg}$. 


\section{B.3 The Paper: Improved Hydrogen Gas Getters for TRU Waste Transuranic and Mixed Waste Focus Area - Phase 2 Final Report}

The paper Improved Hydrogen Gas Getters for TRU Waste Transuranic and Mixed Waste Focus Area-Phase 2 Final Report (INEL/EXT-02-00564) provides the results of tests performed to determine which polymers are the best to coat a hydrogen getter particle. The first task of Phase 1 was to select potentially useful polymers. Membranes having thicknesses in the range of 50 to 200 microns were tested in a pure (single) gas facility at the INEEL (Figure 3). The primary focus of the pure gas test screening has been to determine if the polymers being considered have an $\mathrm{H}_{2}$ permeability high enough to allow $\mathrm{H}_{2}$ to pass through the polymer at the same rate as it is produced, $\sim 5 \times 10^{-10} \mathrm{~cm}^{3}-\mathrm{cm} / \mathrm{sec}-\mathrm{cm}^{2}-\mathrm{cmHg}$. Each polymer was initially tested using six gases that might be seen in a container: $\mathrm{He}, \mathrm{H}_{2}, \mathrm{~N}_{2}, \mathrm{O}_{2}, \mathrm{CH}_{4}$, and $\mathrm{CO}_{2}$. All of the pure gas tests were performed at $30^{\circ} \mathrm{C}\left(86^{\circ} \mathrm{F}\right)$ and 30 psi feed gas pressure.

Table 3 of this reference (Improved Hydrogen Gas Getters ....) presents the results. The permeability of hydrogen through various polymers, in units of $10^{-10} \mathrm{~cm}^{3}-\mathrm{cm} / \mathrm{s}-\mathrm{cm}^{2}-\mathrm{cmHg}$, is:

- $\quad 6.4$ for unplasticized PVC

- $\quad 4.6$ for PVC having a viscosity of 0.62

- $\quad 5.3$ for PVC having a viscosity of 1.02

- 17.3 for polyethylene bag

- 2.4 for PMMA (poly-methyl-methacrylate)

- 25.4 for polystyrene.

\section{B.4 The Paper: Technical Reference On Hydrogen Compatibility Of Materials}

SAND2006-1163, Chapter 8100, Table 2-1, provides the permeability of hydrogen through various polymers. The units are $10^{-9} \mathrm{Mole} / \mathrm{s}-\mathrm{m}-\mathrm{MPa}$ or $10^{-9} \mathrm{Mole}-\mathrm{m} / \mathrm{s}-\mathrm{m}^{2}-\mathrm{MPa}$. The values are:

- $\quad$ Low density polyethylene (LDPE) - 3.3

- Unplasticized PVC -0.58

- $\quad$ PMMA - 1.24

- Polystyrene -7.58 
For PVC, the permeability, using more standard units is:

$$
\begin{gathered}
\frac{0.58 \times 10^{-9} \text { moles }}{s-m-M P a} * \frac{m}{100 \mathrm{~cm}} * \frac{24,450 \mathrm{~cm}^{3}}{m o l e} * \frac{0.101 \mathrm{MPa}}{76 \mathrm{cmHg}}= \\
1.9 \times 10^{-10} \frac{\mathrm{cm}^{3}}{\mathrm{~s}} \frac{\mathrm{cm}}{\mathrm{cm}^{2}-\mathrm{cmHg}} \text { for } P V C
\end{gathered}
$$

Table 2.4 of SAND2006-1163 gives the temperature dependence of the values. The temperature dependence follows the following equation:

$$
P(T)=P_{T, b a s e}\left[\exp \left(-\frac{E}{R T}\right)\right]
$$

where:

$$
\mathrm{P}_{\mathrm{T}, \text { base }}=\text { the permeability at the base temperature } \mathrm{T}_{\text {base }}
$$

Tables 2.2 and 2.4 of SAND2006-1163 provide the data for the equation.

\begin{tabular}{|c|l|l|}
\hline Material & \multicolumn{1}{|c|}{ T $_{\text {base }}, \mathbf{K}$} & E, kJ/mole \\
\hline Unplasticized PVC & 298 & 34.5 \\
\hline
\end{tabular}

\section{B.5 The Paper: CH-TRU Payload Appendices}

CH-TRU Payload Appendices, Revision 1, Table 6.8-5, provides the permeability of a PVC bag of 4.94 E-7 moles/s-mole-frac based on a heat sealed 14-mil thick PVC bag having a surface area of $6.3 \mathrm{ft}^{2}$ (per Table 6.8-1).

The reference also provided a value of 5.6 E-7 moles/s-mole-frac for a "horse-tailed" (i.e., twist and taped), 14-mil thick PVC bag having a surface area of $6.3 \mathrm{ft}^{2}$ (per Table 6.8-1).

Using the following conversion factors:

At $25^{\circ} \mathrm{C}(298 \mathrm{~K}), 1$ moles occupies $24,450 \mathrm{~cm}^{3}$

$14 \mathrm{mil}=0.014 \mathrm{in}$ or $0.0356 \mathrm{~cm}$

$6.3 \mathrm{ft}^{2}=5861 \mathrm{~cm}^{2}$

1 mole frac $=76 \mathrm{cmHg}$.

The permeability of the PVC bag is:

$$
\begin{gathered}
\frac{4.94 E-7 \text { moles }}{\mathrm{s}-\text { mole frac. }} * \frac{24,450 \mathrm{~cm}^{3}}{\text { mole }} * \frac{0.0356 \mathrm{~cm}}{5861 \mathrm{~cm}^{2}} * \frac{\text { mole frac. }}{76 \mathrm{~cm} \mathrm{Hg}}= \\
9.6 \mathrm{E}-10 \frac{\mathrm{cm}^{3}}{\mathrm{~s}} \frac{\mathrm{cm}}{\mathrm{cm}^{2}-\mathrm{cmHg}}
\end{gathered}
$$




\section{B.6 The Paper: Hydrogen Venting Characteristics of Commercial Carbon Composite Filters and Applications to TRU Waste}

The paper, Hydrogen Venting Characteristics of Commercial Carbon-Composite Filters and Applications to TRU Waste, shows $2.9 \times 10^{-7}$ moles/s-mole-fraction for a heat-sealed 14-mil thick PVC bag having an area of $2,800 \mathrm{~cm}^{2}\left(3.01 \mathrm{ft}^{2}\right)$.

Using the following conversion factors:

At $25^{\circ} \mathrm{C}(298 \mathrm{~K}), 1$ moles occupies $24,450 \mathrm{~cm}^{3}$

$14 \mathrm{mil}=0.014 \mathrm{in}$ or $0.0356 \mathrm{~cm}$

1 mole frac $=76 \mathrm{cmHg}$

The permeability of the PVC bag is:

$$
\begin{gathered}
\frac{2.9 \times 10^{-7} \text { moles }}{\mathrm{s}-\text { mole frac. }} * \frac{24,450 \mathrm{~cm}^{3}}{\text { mole }} * \frac{0.0356 \mathrm{~cm}}{2800 \mathrm{~cm}^{2}} * \frac{\text { mole frac. }}{76 \mathrm{cmHg}}= \\
12 \times 10^{-10} \frac{\mathrm{cm}^{3}}{\mathrm{~s}} \frac{\mathrm{cm}}{\mathrm{cm}^{2}-\mathrm{cmHg}}
\end{gathered}
$$

\section{B.7 Summary of Bag Surface Permeability Data}

Table B-1 provides the summary of the permeability data for the bag surface. For PVC bags, the analysis to following Section 6 will use the value of $10 \times 10^{-10} \mathrm{~cm}^{3}-\mathrm{cm} / \mathrm{s}-\mathrm{cm}^{2}-\mathrm{cmHg}$ or $1 \times 10^{-9} \mathrm{~cm}^{3}-\mathrm{cm} / \mathrm{s}-\mathrm{cm}^{2}-\mathrm{cmHg}$ as this value results in the diffusivity matching the test performed at WIPP (See Section 4.5).

Table B-1. Permeability Data

\begin{tabular}{|l|l|c|}
\hline \multicolumn{1}{|c|}{ Mection } & \multicolumn{1}{|c|}{$\begin{array}{c}\text { Permeability, } \\
\mathbf{1 0}^{-\mathbf{1 0}} \mathbf{c m}^{3}-\mathbf{c m} / \mathbf{s}-\mathbf{c m}^{2}-\mathbf{c m H g}\end{array}$} \\
\hline Polyvinyl chloride (PVC) & \multicolumn{2}{|c|}{28.0} \\
\hline 4.2 & PVC & 6.4 \\
\hline 4.3 & Unplasticized PVC & 4.6 \\
\hline 4.3 & $\begin{array}{l}\text { PVC } \\
\text { having a viscosity of } 0.62\end{array}$ & 5.3 \\
\hline 4.3 & $\begin{array}{l}\text { PVC } \\
\text { having a viscosity of } 1.02\end{array}$ \\
\hline 4.4 & Unplasticized PVC & 1.9 \\
\hline 4.5 & PVC bag & 9.6 \\
\hline
\end{tabular}


Table B-1. Permeability Data

\begin{tabular}{|c|c|c|}
\hline Section & Material & $\begin{array}{c}\text { Permeability, } \\
10^{-10} \mathrm{~cm}^{3}-\mathrm{cm} / \mathrm{s}-\mathrm{cm}^{2}-\mathrm{cmHg}\end{array}$ \\
\hline \multirow[t]{2}{*}{4.6} & Heat-sealed PVC bag & 12.0 \\
\hline & Average for PVC & 10 \\
\hline \multicolumn{3}{|c|}{ Polyethylene (PE) } \\
\hline 4.1 & Polyethylene bag & 10.1 \\
\hline 4.3 & PE (polyethylene) bag & 17.3 \\
\hline 4.4 & Low density PE & 10.8 \\
\hline \multicolumn{3}{|c|}{ Poly-methyl-methacrylate (PMMA) } \\
\hline 4.3 & $\begin{array}{l}\text { PMMA } \\
\text { (poly-methyl-methacrylate) }\end{array}$ & 2.4 \\
\hline 4.4 & PMMA & 4.1 \\
\hline \multicolumn{3}{|l|}{ Other } \\
\hline 4.2 & $\begin{array}{l}\text { PU } \\
\text { (polyurethane) }\end{array}$ & 16 \\
\hline 4.3 & $\begin{array}{l}\text { PS } \\
\text { (polystyrene) }\end{array}$ & 24.8 \\
\hline
\end{tabular}

\section{B.8 References}

CH-TRU Payload Appendices, 2009, Rev. 2, Waste Isolation Pilot Plant, Carlsbad, New Mexico. (Rev. 1, 2004 is found at http://pbadupws.nrc.gov/docs/ML0430/ML043000139.pdf)

Hydrogen Venting Characteristics of Commercial Carbon-Composite Filters and Applications to TRU Waste, 1994, LA-13284, Los Alamos National Laboratory, Los Alamos, New Mexico. Found at: http://www.osti.gov/bridge/servlets/purl/4714067xyTsY/webviewable/471406.pdf

ICP/CON-04-00563, 2005, High Hydrogen Concentrations Detected In The Underground Vaults For RH-TRU Waste At INEEL Compared With Calculated Values Using The INEELDeveloped Computer Code, Idaho completion Project, Bechtel BWXT Idaho, LLC, Idaho Falls, Idaho. Found at: http:/www.inl.gov/technicalpublications/Documents/3169740.pdf

Improved Hydrogen Gas Getters for TRU Waste Transuranic and Mixed Waste Focus AreaPhase 2 Final Report, 2002, INEL/EXT-02-00564, Idaho National engineering and Environmental Laboratory, Bechtel BWXT Idaho, LLC, Idaho falls, Idaho. Found at: http://www.inl.gov/technicalpublications/Documents/2670755.pdf. 
Measurement Of Hydrogen Diffusion Rates Through Both "Twist And Tape” And Heat-Sealed Polyurethane And Polyvinyl Chloride Bags, 2000, Paper given at the Waste Management 2000 conference, held Feb 27 - March 2, 2000 in Tucson, Arizona. Authors TJ

Wickland and Don Dustin. Found at: http://www.wmsym.org/archives/2000/pdf/31/3141.pdf

SAND2006-1163, 2006, Technical Reference on Hydrogen Compatibility of Material, Chapter 8100, "Polymers of the reference Technical Reference on Hydrogen Compatibility of Materials," Sandia National Laboratory, Albuquerque, New Mexico. Found at: http://www.sandia.gov/matlsTechRef/chapters/8100TechRef polymers.pdf 


\section{Appendix C}

\section{A Literature Search for Values for Permeability of the Diffusivity of Twist and Tape Closures on Plastic Bags}




\section{Appendix C \\ A Literature Search for Values for Permeability of the Diffusivity of Twist and Tape Closures on Plastic Bags}

A literature search was performed to determine the diffusivity for twist and tape closures for plastic bags. The results are shown below. In addition, Section 3.5 proposed a theory as to the pathway for hydrogen escape from the closure that explains the relatively high values of diffusivity coming from a relatively small surface.

\section{C.1 The Paper: Measurement of Hydrogen Diffusion Rates Through both "Twist and Tape" and Heat-Sealed Polyurethane and Polyvinyl Chloride Bags}

Table 2 of the paper, Measurement of Hydrogen Diffusion Rates through both "Twist and Tape" and Heat-Sealed Polyurethane and Polyvinyl Chloride Bags, shows the values of hydrogen diffusivity through PU and PVC bags with twist and taped ends, corrected to $25^{\circ} \mathrm{C}$. The bags were 14 mil PVC or 6 mil PU bags that are sealed at one or two ends by securely twisting a portion of the bag, wrapping tape around the twisted end, cutting the tape at the midpoint of the taped length and adding a layer of tape to seal off the "open" end (i.e., the end that was just cut).

The bag end was cut to fit onto a 10-in. diameter PVC pipe (called the test vessel). A photo of the set-up showed a relatively flat bag surface stretched across the 10-in. pipe with a 4-in. long, twisted, and taped closure laying on the bag surface. Hydrogen diffused through the bag surface and the twist.

The two-run average hydrogen diffusion rate through the twisted and taped bag ends was:

- $5.2 \times 10^{-7}$ Moles/s-mole-fraction for Polyurethane (PU)

- $4.4 \times 10^{-7}$ Moles/s-mole-fraction for PVC

The fraction of the diffusion rate, hydrogen diffusing through the surface, is found as follows:

The permeability from Section 4.2 is used. Section 4.2 provides the permeability of PVC bags from the same test. It is:

$$
28 \times 10^{-10} \frac{\mathrm{cm}^{3}}{\mathrm{~s}} \frac{\mathrm{cm}}{\mathrm{cm}^{2}-\mathrm{cmHg}}
$$

Assume that the hydrogen diffuses through the surface.

Using the following conversion factors:

At $25^{\circ} \mathrm{C}(298 \mathrm{~K}), 1$ moles occupies $24,450 \mathrm{~cm}^{3}$,

$14 \mathrm{mil}=0.014$ in or $0.0356 \mathrm{~cm}$, 
1 mole frac $=76 \mathrm{cmHg}$,

Area $=507 \mathrm{~cm}^{2}$ (top) $+203 \mathrm{~cm}^{2}$ (the side) $=710 \mathrm{~cm}^{2}$ (The bag is assumed to be a cylinder that is 1 -in. tall and $10 \mathrm{in}$. in diameter. The cylinder is presumed to have some height because of the folds shown in Figure 1. The bag is not flat on the surface of the 10-in. diameter pipe. The surface area is the top surface and the sides of the bag).

The diffusivity is:

$$
\begin{gathered}
28 \times 10^{-10} \frac{\mathrm{cm}^{3}}{\mathrm{~s}} \\
\frac{\mathrm{cm} \mathrm{cm}^{2}-\mathrm{cmHg}}{24,450 \mathrm{~cm}^{3}} * \frac{710 \mathrm{~cm}^{2}}{0.0356 \mathrm{~cm}} * 76 \mathrm{~cm} \mathrm{Hg} \\
=1.74 \times 10^{-7} \frac{\text { moles }}{\mathrm{s}-\text { molefrac }}
\end{gathered}
$$

This shows that about 40 percent of the diffusion goes through the surface and the remainder through the twisted and taped closure. (Note that Section 4.2 shows that the diffusivity of the heat sealed bag is $1.71 \times 10^{-7}$. This is essentially the same as that calculated above).

The diffusivity of the twist and taped section is $2.7 \times 10^{-7} \mathrm{moles} / \mathrm{s}-\mathrm{mole}$ fraction. This is found by obtaining the difference between the diffusivity of the bag with the twist and tape section (4.4 $\left.\mathrm{x} 10^{-7}\right)$ and the diffusivity of the bag, alone $\left(1.7 \times 10^{-7}\right)$.

\section{C.2 The Paper: Hydrogen Venting Characteristics of Commercial Carbon-Composite Filters and Applications to TRU Waste}

Table 2-3 of the paper Hydrogen Venting Characteristics of Commercial Carbon-Composite Filters and Applications to TRU Waste shows a diffusion coefficient of $7.6 \times 10^{-7} \mathrm{moles} / \mathrm{s}-\mathrm{mole}$ fraction for PVC bags closed with "horse-tails." The values ranged from $6.63 \times 10^{-7} \mathrm{moles} / \mathrm{s}-$ mole-fraction to $12 \times 10^{-7} \mathrm{moles} / \mathrm{s}-$ mole-fraction. The bag was 14-mil thick. The "horse-tail" involved a $25 \mathrm{~cm}$ (10 in.) length of bag that was tightly twisted, taping the twist and then cutting through the center of the twist and taping over the cut end. The bag had an area of $2,800 \mathrm{~cm}^{2}$.

Section 4.6 showed that the diffusivity through a sealed bag of this size was $2.9 \times 10^{-7}$ moles/s-mole fraction. The diffusivity of the twist and taped section is the difference between the diffusivity of the bag with the twist and tape section and the diffusivity of the bag, alone, or $4.7 \times 10^{-7}$ moles/s-mole fraction. Using the diffusivity of the bag and twist, and the taped portion of $7.6 \times 10^{-7}$, about 40 percent of the diffusion goes through the surface area, with the remainder through the twist.

\section{C.3 The Paper: CH-TRU Payload Appendices}

CH-TRU Payload Appendices, Revision 1, Section 6.8.7.2.2, states that the diffusivity through the bag surface alone, is $4.97 \times 10^{-7}$ moles/s-mole-fraction. This is shown in Table 6.8-3 for Test 9B and in Table 6.8-5. Section 6.8.7.2.2, states that the diffusivity of the twist-and-taped section (the "horse-tail"), alone, is 5.6 E-7 moles/s-mole-fraction. This value is obtained by 
subtracting the diffusivity of Test 9A from Test 9C. In each case, a 14-mil thick PVC bag having a surface area of $6.3 \mathrm{ft}^{2}$ (per Table 6.8-1) was used in the test. In this case, about 50 percent of the hydrogen flow goes through the bag walls. This fraction is much larger than it was in the cases shown in Sections 5.1 and 5.2 because the surface area is much greater $\left(5,860 \mathrm{~cm}^{2}\right.$ for this case, $2,800 \mathrm{~cm}^{2}$ for Section 5.2 and $710 \mathrm{~cm}^{2}$ for Section 5.1$)$.

The length of the twist and tape portion is approximated as follows. The initial bag dimension is 10 by $72 \mathrm{in.} \mathrm{The} \mathrm{surface} \mathrm{area} \mathrm{of} \mathrm{the} \mathrm{finished} \mathrm{bag} \mathrm{is} 6.3 \mathrm{ft}^{2}$. Assume that the bag is essentially flat (that is the configuration in the tests shown in Section 6.8 of CH-TRU Payload Appendices). Given a width of $10 \mathrm{in}$., the length of the bag to yield a surface area of $6.3 \mathrm{ft}^{2}$ is $45 \mathrm{in}$. This means that the initially twisted length is about 27 in. Assuming that the twisted portion is cut in half, the twist and tape length is about 13 in.

\section{C.4 Summary of Diffusivity of Twist and Taped ("Horse-Tailed”) Closures}

The diffusivity of twist and taped closures, alone, of PVC bags was measured and found to be:

- $2.2 \times 10^{-7}$ moles/s-mole-fraction for a relatively flat bag surface stretched across the 10 in. pipe $\left(710 \mathrm{~cm}^{2}\right.$ area) with a 4 -in. long, twisted and taped, closure laying on the bag surface (Case C.1),

- $4.7 \times 10^{-7}$ moles/s-mole fraction for a 14-mil thick, $2,800 \mathrm{~cm}^{2}$ bag having a "horse-tail" that involved a $25 \mathrm{~cm}$ (10 in.) length of bag that was tightly twisted, taping the twist and then cutting through the center of the twist and taping over the cut end (Case C.2).

- $\quad 5.6 \times 10^{-7} \mathrm{moles} / \mathrm{s}-m o l e$ fraction for a "horse-tailed" (i.e., twist and taped), 14-mil thick PVC bag having a surface area of $5,860 \mathrm{~cm}^{2}\left(6.3 \mathrm{ft}^{2}\right)$. The twist and tape portion is about 13 in. long (Case 3).

Note that there is a linear relationship between the length of the twist and tape portion and the diffusivity.

\section{C.5 Hydrogen Transport Path Out The Twist And Tape Closure}

Sections C. 1 to C. 3 show that the large fraction (around 40 percent) of hydrogen is transported out of the twist and tape closure. The surface area of the twist and tape enclosure is much smaller than the surface of the bag. The thickness of the plastic in the twist and tape closure is much greater than that of the bag. As a result, the diffusivity of the twist and tape region should be much smaller. Hydrogen diffusion flow out the sides of the twist and tape portion is much smaller than it is out of the bag, simply because the area of the twist and tape portion is much less than the bag and the thickness of the plastic in the twist and tape portion is thicker than the bag itself. As a result, hydrogen transport out of the sides, due to diffusion, is quite small. The same is true for diffusion out of the taped end. In this case, the area for the flow is very small (the area of the core), while the thickness across which hydrogen diffuses is likely is about the same as the bag. However, the tests show that the diffusivity through the twist and tape portion is about the same magnitude as the diffusivity of the bag surface. 
To achieve a high diffusivity, the twist and tape portion must contain a "core" region, which has the same concentration of hydrogen as does the remainder of the bag. The core region is not necessarily cylindrical or straight, but is present as a path of some dimension through the twist and tape region. Most of the hydrogen transported out of the twist and tape region, flows out through this core and out to the atmosphere via open pathways under the tape.

To show the size of the core, consider the following. HNF-16166, Appendix B, "Required Staging Times for Hydrogen diffusion in Vented Waste Containers," provides a method to determine the diffusivity through on opening in a container (like an opening in a drum liner or in the shaft of a filter). The method is based on a heat transfer analogy equating one-dimensional heat flow with diffusion flow. The resistance of the opening is found first. The diffusivity is found from the resistance.

Using the equation in HNF-16166, Appendix B, page B-1, the resistance of the opening is found to be:

$$
R=\frac{x}{A D} * \frac{1000 \mathrm{~cm}^{3}}{\mathrm{~L}}
$$

The subsection of HNF-16166, Appendix B, "Extension of the Model to the Filters," shows the diffusivity (units of moles/s-mole fraction) is found from the following:

$$
\text { Diffusivity }=\frac{1}{\mathrm{R} * 24.45 \mathrm{~L} / \mathrm{mole}}
$$

The method of HNF-16166, Appendix B, is used in the subsection of Appendix C titled "Manufacturer's Data and the Resistance Calculation" to determine the diffusivity of the Nuclear Filter Technology ("NucFil") Model 007LS filter. The calculated diffusivity was found to be 1.06 times greater than the manufacturer's value, a good result for this complicated filter.

Of the three cases discussed in Sections C.1 - C.3, the data from Section C.1 is discussed here for illustration of the concept. In the case to be studied here (diffusion through a small diameter channel through the twist and tape closure and out under the tape to the environment), assume that the twisted and taped portion is $4 \mathrm{in} .(10 \mathrm{~cm})$. The equation for diffusivity will be solved for the area of the channel, knowing the path length and the diffusivity.

From above, the diffusivity of an open pathway is obtained from

$$
\text { Diffusivity, } \frac{\text { moles }}{s-\text { mole fraction }}=\left[\frac{x}{A D} * \frac{24,450 \mathrm{~cm}^{3}}{\text { mole }}\right]^{-1}
$$


where:

$$
\begin{aligned}
\mathrm{x} & =\text { length of the path, } \mathrm{cm}, \\
& =10 \mathrm{~cm} \text { (or } 4 \text { in.), in this case, } \\
\mathrm{A} & =\text { cross-sectional area of the path, } \mathrm{cm}^{2}, \text { and } \\
\mathrm{D} & =\text { diffusion constant of hydrogen, } \mathrm{cm}^{2} / \mathrm{s}, \\
& =0.75 \mathrm{~cm}^{2} / \mathrm{s} \text { (per HNF-16166, Appendix C). }
\end{aligned}
$$

Section C. 1 shows the diffusivity of the 4-in. long twist and tape is $2.7 \times 10^{-7}$ moles/s-mole fraction. Given this, the area must be $0.09 \mathrm{~cm}^{2}$. This is equal to a circle having a diameter of 0.13 in. or about $1 / 8$ in. That is, an equivalent of a $1 / 8$ in. core through the twist and tape and the equivalent of a 1/8 in. diameter opening underneath the tape will yield the hydrogen flows seen through the tape. Since the cut end is jagged and the tape is wrapped over the cut end, a number of small open pathways exist from the core, under the taped portion (that are not tightly bound to the plastic) and out to the atmosphere. This is why the diffusion is so great out of the closure.

Section C. 2 shows a diffusivity of the $13 \mathrm{in}$. long twist and tape portion is $5.6 \times 10^{-7} \mathrm{moles} / \mathrm{s}-$ mole fraction. Using the equation above, the area is found to be $0.6 \mathrm{~cm}^{2}$. The equivalent diameter of the opening is 0.34 in. The equivalent diameter of the open channel is greater for this longer twist and tape portion. This could be because of one or more of the following:

- It is more difficult to twist a longer length of bag to the same tightness as is possible for a smaller length.

- The procedures for twisting differ.

- The operator's attention to twist tightness differed.

- The tape was applied more loosely (or the top of the twist and tape portion was more "lumpy").

The only way the diffusivity of the twist and tape portion can be the value found in the tests is for hydrogen to diffuse through an open channel in the twist and tape portion and out through the openings under the tape. Bending the twist and tape portion over will not completely close off the inner open core, but it might restrict flow to some extent, possibly resulting in a lower diffusivity.

The diffusivity out of the twist and tape portion is a function of the length of the twist and tape portion. It is also likely from a function of the tightness of the twist, the method and the extent to which the end is taped.

However, since an opening existed for three different tests of a twist and tape portion involving three different operators, it is assumed that the diffusivity of the twist and tape portion of a waste package is non-zero. In the analysis that follows, the diffusivity of the twist and tape portion is chosen to be from Section 5.3, or, $5.6 \times 10^{-7}$ moles/s-mole fraction. A sensitivity analysis will be performed using a factor of 10 less than this $5.6 \times 10^{-8}$ moles $/ \mathrm{s}-$ mole fraction. This is 20 percent of the lowest value found in the tests $\left(2.7 \times 10^{-7} \mathrm{moles} / \mathrm{s}-\mathrm{mole}\right.$ fraction $)$. 


\section{C.6 References}

CH-TRU Payload Appendices, 2009, Rev. 2, Waste Isolation Pilot Plant, Carlsbad, New Mexico. (Rev. 1, 2004 is found at http://pbadupws.nrc.gov/docs/ML0430/ML043000139.pdf)

HNF-16166, 2006, Required Staging Times for Hydrogen diffusion in Vented Waste Containers, Rev. 7, Fluor Hanford, Inc., Richland, Washington.

Hydrogen Venting Characteristics of Commercial Carbon-Composite Filters and Applications to TRU Waste, 1994, LA-13284, Los Alamos National Laboratory, Los Alamos, New Mexico. Found at: http://www.osti.gov/bridge/servlets/purl/4714067xyTsY/webviewable/471406.pdf

Measurement Of Hydrogen Diffusion Rates Through Both “Twist And Tape” And Heat-Sealed Polyurethane And Polyvinyl Chloride Bags, 2000, Paper given at the Waste Management 2000 conference, held Feb 27 - March 2, 2000 in Tucson, Arizona. Authors TJ Wickland and Don Dustin. Found at: http://www.wmsym.org/archives/2000/pdf/31/31$\underline{41 . p d f}$ 
CHPRC-01674, Rev. 1

This page is intentionally left blank. 
CHPRC-01674, Rev. 1

\section{Appendix D}

E-Mail from Murthy Devarakonda, WIPP, Giving the Diffusivities Used by WIPP 


\title{
Appendix D \\ E-Mail from Murthy Devarakonda, WIPP, Giving the Diffusivities Used by WIPP
}

\section{Marusich, Robert M}

Subject:

Attachments:
FW: Regarding Data needed to determine $\mathrm{H} 2$ concentration in inner bags - Hanford ConfinementLayerReleaseRates.docx

From: Devarakonda, Murthy - WTS [mailto:Murthy,Devarakonda@wipp.ws]

Sent: Tuesday, August 02, 2011 2:17 PM

To: Marusich, Robert M; Brown, Mike - DOE

Cc: Colburn, Alan J.; Danna, Marc; Ploetz, David - WTS; Pearcy, Mark - WTS; Bledscheid, Jennifer - WTS

Subject: RE: Regarding Data needed to determine $\mathrm{H} 2$ concentration in inner bags - Hanford

Bob:

Attached is a summary of the release rates for the different confinement layers used in the CH-TRAMPAC calculations.

\section{Attachment to Email}

\author{
Release Rates for Confinement Layers \\ From CH-TRU Payload Appendices
}

\begin{tabular}{|l|c|}
\hline Layer & $\begin{array}{c}\text { Waste Types II } \\
\text { and III (mol/s/mf) }\end{array}$ \\
\hline Small twist-and-tape inner bag & $5.58 \mathrm{E}-7$ \\
\hline Large twist-and-tape liner bag & $4.67 \mathrm{E}-6$ \\
\hline Filtered inner bag & $1.074 \mathrm{E}-5$ \\
\hline Filtered liner bag & $1.486 \mathrm{E}-5$ \\
\hline Rigid drum liner (0.3"-dia hole) & $5.076 \mathrm{E}-5$ \\
\hline Drum filter (1X) & $3.70 \mathrm{E}-6$ \\
\hline Drum Filter (5X) & $1.85 \mathrm{E}-5$ \\
\hline
\end{tabular}


CHPRC-01674, Rev. 1

\section{Appendix E}

Sensitivity Analyses Performed with 6-Bag Spreadsheet Modeling the TRUCON Code Configurations 


\section{Appendix E \\ Sensitivity Analyses Performed with 6-Bag Spreadsheet Modeling the TRUCON Code Configurations}

The analysis in this sections shows how the results from the model compare with the results of the WIPP analysis of the various containers and waste packages. The inventories, used in the analysis, are shown in Table E-1 (next page). These inventories apply to the debris waste streams (RH 125/225 TRUCON Code). This table came from Appendix F, "Attachment From E-Mail Regarding Gram Limit Guidance for Debris Waste Streams." The debris waste streams consist of: surgical gloves, plastic bags and sheets, paper products, cloth, tape, rubber, leaded glass, lead-lined hood gloves, lead blankets, light bulbs, flashlight batteries, piping, conduit, wiring, glass and metal portions of gloveboxes, pumps, motors, standard laboratory equipment, and various other debris.

Per the guidance of the TRUCON manual, the following values are used in the analysis:

- Each filtered plastic bag has a diffusivity of $1.075 \times 10^{-5}$ moles per second per mole fraction.

- Each filtered metal can has a diffusivity of $1.9 \times 10^{-6}$ moles per second per mole fraction.

- Each pipe component has a diffusivity of $1.9 \times 10^{-6}$ moles per second per mole fraction.

- Each 55-gallon drum has a rigid liner punctured with a 0.3-in. diameter hole.

- Each 85-gallon drum used to overpack a 55-gallon drum has a diffusivity of $3.7 \times 10^{-6}$ moles per second per mole fraction.

- Each standard waste box (SWB) used to overpack 55-gallon drums (SWB overpack) has a diffusivity of $7.4 \times 10^{-6}$ moles per second per mole fraction.

Other data shown in Appendix D is also used.

The Plutonium limit for the package configurations is shown in the table below. 
Table E-1. Pu limit for Various Package Configurations from TRUCON Code RH 125/225 (“Gram Limit Guidance for Debris Waste Streams”)

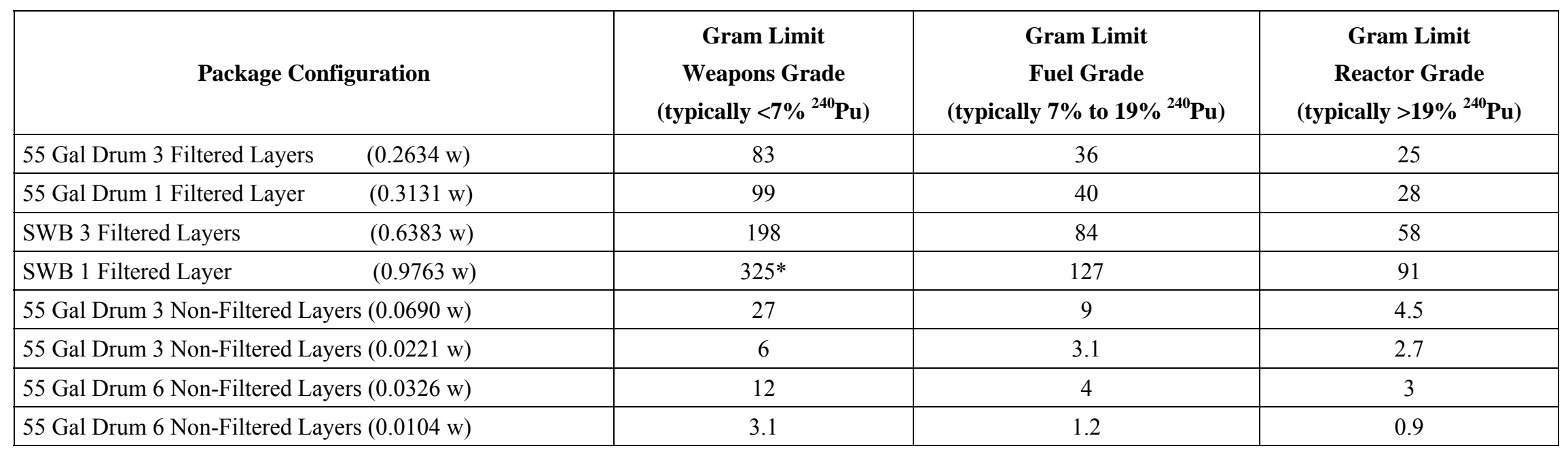

*Fissile Gram Equivalent 
A number of these cases will be checked using the model. In each case, the plutonium quantity is based on the "fuels grade" value. Since the Plutonium Finishing Plant does not typically package with non-filtered, heat sealed bags, only the "filtered" cases and the non-filtered cases assuming that twist and tape closure is used.

The data required is shown in Table E-2.

E.1.1.1.1 Table E-2. Data used for the TRUCON Code Comparison

\begin{tabular}{|l|l|l|}
\hline \multicolumn{1}{|c|}{ Layer } & $\begin{array}{c}\text { Diffusivity for Waste Types II and } \\
\text { III (mol/s/mole-fraction), from } \\
\text { Appendix 2 }\end{array}$ & \multicolumn{1}{|c|}{ Other references } \\
\hline $\begin{array}{l}\text { Small twist-and-tape closure } \\
\text { (just the closure, not the bag } \\
\text { surface) } \\
\text { (See Note 1) }\end{array}$ & $5.6 \mathrm{E}-7$ & $\begin{array}{l}\text { Table 6.8.5 of CH-TRU Payload } \\
\text { Appendices }\end{array}$ \\
\hline $\begin{array}{l}\text { Non-filtered and non-twist-and- } \\
\text { taped bag } \\
\text { (i.e., the bag surface) }\end{array}$ & $4.94 \mathrm{E}-7$ & $\begin{array}{l}\text { Table 6.8.5 of CH-TRU Payload } \\
\text { Appendices }\end{array}$ \\
\hline $\begin{array}{l}\text { Small bag with a twist and tape } \\
\text { closure }\end{array}$ & $1.054 \mathrm{E}-6$ & $\begin{array}{l}\text { Obtained by adding the diffusivity } \\
\text { for the twist and tape closure to that } \\
\text { for the bag surface. }\end{array}$ \\
\hline Filtered inner bag & $\begin{array}{l}\text { DOE/WIPP 01-3194, Table 2C, } \\
\text { Content code ID 112O, (Page 2-23) } \\
\text { and other ID-XXX codes. } \\
\text { Also shown in Appendix D }\end{array}$ \\
\hline Rigid drum liner (0.3"-dia hole) & $5.076 \mathrm{E}-5$ & $\begin{array}{l}\text { Calculated as 6.0 x 10-5 using the } \\
\text { equation in Section 6.2.1 with the } \\
\text { liner thickness as 90 mil and hole } \\
\text { diameter as 0.3 in.. }\end{array}$ \\
\hline Drum filter (1X) & $\begin{array}{l}\text { DOE/WIPP 01-3194, Table 2A. } \\
\text { Also shown in Appendix D }\end{array}$ \\
\hline
\end{tabular}

Notes:

Bag area is $5,861 \mathrm{~cm}^{2}\left(6.3 \mathrm{ft}^{2}\right)$ per Table $6.8-1$ of Chapter 6.8 of the $C H$-TRU Payload Appendices.

\section{Case 1}

Case 1 presents the results using the model for the TRUCON Code case of three filtered bags. The input data is shown in Table E-3. 
CHPRC-01674, Rev. 1

\section{E.1.1.1.2 Table E-3. Input for the 3-Filtered Bag Case in the TRUCON Code Comparison}

\begin{tabular}{|c|c|c|c|c|c|c|c|c|}
\hline & Bag 1 & Bag 2 & Bag 3 & Bag 4 & Bag 5 & Bag 6 & Liner & Drum \\
\hline \multicolumn{9}{|l|}{$\begin{array}{l}\text { Permeability, } \\
\mathrm{cm} 3-\mathrm{cm} / \mathrm{s}-\mathrm{cm} 2-\mathrm{cmHG}\end{array}$} \\
\hline \multicolumn{9}{|l|}{ Bag thickness, mil } \\
\hline \multicolumn{9}{|l|}{ Bag thickness, cm } \\
\hline \multicolumn{9}{|l|}{ Bag height, in } \\
\hline \multicolumn{9}{|l|}{ Bag height, $\mathrm{cm}$} \\
\hline \multicolumn{9}{|l|}{ Bag diameter, in } \\
\hline \multicolumn{9}{|l|}{ Bag diameter, $\mathrm{cm}$} \\
\hline \multicolumn{9}{|l|}{ Bag surface area, $\mathrm{cm} 2$} \\
\hline \multicolumn{9}{|l|}{$\mathrm{cmHg} / \mathrm{mole}$ frac } \\
\hline \multicolumn{9}{|l|}{$\mathrm{cm} 3 /$ mole at $298 \mathrm{~K}(25 \mathrm{C})$} \\
\hline $\begin{array}{l}\text { Diffusivity, moles/s-mole } \\
\text { frac }\end{array}$ & $1.07 \mathrm{E}-05$ & $1.07 \mathrm{E}-05$ & $1.07 \mathrm{E}-05$ & $1.00 \mathrm{E}+00$ & $1.00 \mathrm{E}+00$ & $1.00 \mathrm{E}+00$ & $5.08 \mathrm{E}-05$ & $3.70 \mathrm{E}-06$ \\
\hline Hydrogen transport & 1 to 2 & 2 to 3 & 3 to 4 & 4 to 5 & 5 to 6 & 6 to 7 & 7 to 8 & 8 to atmos \\
\hline
\end{tabular}

\begin{tabular}{|l|c|}
\hline \multicolumn{1}{|c|}{ Parameter } & Value \\
\hline Power used in the calculation, Watts & 0.2624 \\
\hline $\mathrm{G}\left(\mathrm{H}_{2}\right)$, molecules/100 ev & 1.6 \\
\hline $\begin{array}{l}\text { Hydrogen generation rate obtained using the power, } \\
\text { moles/s }\end{array}$ & $4.359 \mathrm{E}-8$ \\
\hline
\end{tabular}




\section{Results from the spreadsheet}

The generation rate was from 0.2624 watts. This equates to a generation rate of $4.375 \mathrm{E}-8$ moles/s using a value of G(H2) of 1.6 from CH-TRU Payload Appendices, Appendix 3.2 (the worst case condition). This same generation rate occurs with $40.6 \mathrm{~g}$ of the $>10 \%{ }^{240} \mathrm{Pu}$ mixture having a curie-weighted average alpha energy of $5.34 \mathrm{Mev}$.

Using the steady state model, the following results were obtained:

\begin{tabular}{|l|c|}
\hline $\begin{array}{c}\text { Bag number (starting } \\
\text { with the inner bag as } \\
\text { bag 1) }\end{array}$ & $\begin{array}{c}\text { Hydrogen } \\
\text { fraction } \\
\text { (steady state) }\end{array}$ \\
\hline $\mathrm{n}, 8 / \mathrm{n}, \mathrm{t}$ (Drum) & 0.0118 \\
\hline $\mathrm{n}, 7 / \mathrm{n}, \mathrm{T} \quad$ (Liner) & 0.0126 \\
\hline $\mathrm{n}, 6 / \mathrm{n}, \mathrm{T} \quad$ (bag 6) & 0.0126 \\
\hline $\mathrm{n}, 5 / \mathrm{n}, \mathrm{T} \quad$ (Bag 5) & 0.0126 \\
\hline $\mathrm{n}, 4 / \mathrm{n}, \mathrm{T} \quad$ (Bag 4) & 0.0126 \\
\hline $\mathrm{n}, 3 / \mathrm{N}, \mathrm{T}$ (bag 3) & 0.0167 \\
\hline $\mathrm{n}, 2 / \mathrm{n}, \mathrm{T} \quad$ (Bag 2) & 0.0208 \\
\hline $\mathrm{n}, 1 / \mathrm{n}, \mathrm{T}$ (Inner Bag) & 0.0248 \\
\hline
\end{tabular}

The steady state plutonium concentration in the inner bag is 2.5 percent. This is less than 4 percent.

\section{Case 2}

Case 2 presents the results using the model for the TRUCON Code case of 1 filtered bag. The input data is shown in Table E-4. 


\section{E.1.1.1.3 Table E-4. Input for the 1-Filtered Bag Case in the TRUCON Code Comparison}

\begin{tabular}{|c|c|c|c|c|c|c|c|c|}
\hline & Bag 1 & Bag 2 & Bag 3 & Bag 4 & Bag 5 & Bag 6 & Liner & Drum \\
\hline \multicolumn{9}{|l|}{$\begin{array}{l}\text { Permeability, } \\
\mathrm{cm} 3-\mathrm{cm} / \mathrm{s}-\mathrm{cm} 2-\mathrm{cmHg}\end{array}$} \\
\hline \multicolumn{9}{|l|}{ Bag thickness, mil } \\
\hline \multicolumn{9}{|l|}{ Bag thickness, cm } \\
\hline \multicolumn{9}{|l|}{ Bag height, in } \\
\hline \multicolumn{9}{|l|}{ Bag height, cm } \\
\hline \multicolumn{9}{|l|}{ Bag diameter, in } \\
\hline \multicolumn{9}{|l|}{ Bag diameter, $\mathrm{cm}$} \\
\hline \multicolumn{9}{|l|}{ Bag surface area, cm2 } \\
\hline \multicolumn{9}{|l|}{$\mathrm{cmHg} /$ mole frac } \\
\hline \multicolumn{9}{|l|}{$\mathrm{cm} 3 /$ mole at $298 \mathrm{~K}(25 \mathrm{C})$} \\
\hline $\begin{array}{l}\text { Diffusivity, moles/s-mole } \\
\text { frac }\end{array}$ & $1.07 \mathrm{E}-05$ & $1.00 \mathrm{E}+00$ & $1.00 \mathrm{E}+00$ & $1.00 \mathrm{E}+00$ & $1.00 \mathrm{E}+00$ & $1.00 \mathrm{E}+00$ & $5.08 \mathrm{E}-05$ & $3.70 \mathrm{E}-06$ \\
\hline Hydrogen transport & 1 to 2 & 2 to 3 & 3 to 4 & 4 to 5 & 5 to 6 & 6 to 7 & 7 to 8 & 8 to atmos. \\
\hline
\end{tabular}

\begin{tabular}{|l|c|}
\hline Parameter & Value \\
\hline Power used in the calculation, Watts & 0.3131 \\
\hline $\mathrm{G}\left(\mathrm{H}_{2}\right)$, molecules/100 ev & 1.6 \\
\hline $\begin{array}{l}\text { Hydrogen generation rate obtained using the power, } \\
\text { moles/s }\end{array}$ & $5.201 \mathrm{E}-8$ \\
\hline
\end{tabular}




\section{Results from the spreadsheet}

The generation rate was from 0.3131 watts ( $40 \mathrm{~g}$ of fuels grade plutonium per the table above). This equates to a generation rate of 5.2E-8 moles/s using a value of $\mathrm{G}(\mathrm{H} 2)$ of 1.6 from $C H-T R U$ Payload Appendices, Appendix 3.2 (the worst case). This same generation rate occurs with $49 \mathrm{~g}$ of the $>10 \%{ }^{240} \mathrm{Pu}$ mixture having a curie-weighted average alpha energy of $5.34 \mathrm{Mev}$.

Using the steady state model, the following results were obtained:

\begin{tabular}{|l|l|}
\hline $\begin{array}{c}\text { Bag number (starting } \\
\text { with the inner bag as } \\
\text { bag 1) }\end{array}$ & $\begin{array}{c}\text { Hydrogen } \\
\text { fraction (steady } \\
\text { state) }\end{array}$ \\
\hline $\mathrm{n}, 8 / \mathrm{n}, \mathrm{t} \quad$ (Drum) & 0.0141 \\
\hline $\mathrm{n}, 7 / \mathrm{n}, \mathrm{T} \quad$ (Liner) & 0.0151 \\
\hline $\mathrm{n}, 6 / \mathrm{n}, \mathrm{T} \quad$ (bag 6) & 0.0151 \\
\hline $\mathrm{n}, 5 / \mathrm{n}, \mathrm{T}$ (Bag 5) & 0.0151 \\
\hline $\mathrm{n}, 4 / \mathrm{n}, \mathrm{T} \quad$ (Bag 4) & 0.0151 \\
\hline $\mathrm{n}, 3 / \mathrm{N}, \mathrm{T}$ (bag 3) & 0.0151 \\
\hline $\mathrm{n}, 2 / \mathrm{n}, \mathrm{T} \quad$ (Bag 2) & 0.0151 \\
\hline $\mathrm{n}, 1 / \mathrm{n}, \mathrm{T}$ (Inner Bag) & 0.0199 \\
\hline
\end{tabular}

The steady state plutonium concentration in the inner bag is $2 \%$. This is less than $4 \%$.

\section{Case 3}

Case 3 presents the results using the model for the TRUCON Code case of 6 non-filtered bags. It is assumed that the bags have twist and tape closures on each. The input data is shown in Table E-5. The permeability for the inner bag (Bag 1) was adjusted so that the diffusivity is as close as possible to those in Table $11\left(1.054 \times 10^{-6}\right.$ moles/s-mole fraction). The permeability for the other bags was set equal to those from the inner bag. The diffusivities for the other bags change as the surface area changes. 
CHPRC-01674, Rev. 1

Table E-5. Input for the 6 Non-Filtered Bag Case in the TRUCON Code Comparison (with "Horse-tails")

\begin{tabular}{|c|c|c|c|c|c|c|c|c|}
\hline & Bag 1 & Bag 2 & Bag 3 & Bag 4 & Bag 5 & Bag 6 & Liner & Drum \\
\hline $\begin{array}{l}\text { Permeability, } \mathrm{cm} 3-\mathrm{cm} / \mathrm{s}-\mathrm{cm} 2- \\
\mathrm{cmHg}\end{array}$ & $2.06 \mathrm{E}-09$ & $2.06 \mathrm{E}-09$ & $2.06 \mathrm{E}-09$ & $2.06 \mathrm{E}-09$ & $2.06 \mathrm{E}-09$ & $2.06 \mathrm{E}-09$ & & \\
\hline Bag thickness, mil & 14 & 14 & 14 & 14 & 14 & 14 & & \\
\hline Bag thickness, cm & 0.0356 & 0.0356 & 0.0356 & 0.0356 & 0.0356 & 0.0356 & & \\
\hline Bag height, in & 17 & 17.5 & 18 & 18.5 & 19 & 19.5 & & \\
\hline Bag height, $\mathrm{cm}$ & 43.18 & 44.45 & 45.72 & 46.99 & 48.26 & 49.53 & & \\
\hline Bag diameter, in & 17 & 17.5 & 18 & 18.5 & 19 & 19.5 & & \\
\hline Bag diameter, cm & 43.18 & 44.45 & 45.72 & 46.99 & 48.26 & 49.53 & & \\
\hline Bag surface area, cm2 & 5857.53 & 6207.16 & 6566.92 & 6936.82 & 7316.85 & 7707.01 & & \\
\hline $\mathrm{cmHg} /$ mole frac & 76 & 76 & 76 & 76 & 76 & 76 & & \\
\hline $\mathrm{cm} 3 /$ mole at $298 \mathrm{~K}(25 \mathrm{C})$ & 24454 & 24454 & 24454 & 24454 & 24454 & 24454 & & \\
\hline $\begin{array}{l}\text { Diffusivity, moles/s-mole } \\
\text { frac (note 1) }\end{array}$ & $1.055 \mathrm{E}-06$ & $1.118 \mathrm{E}-06$ & $1.182 \mathrm{E}-06$ & $1.249 \mathrm{E}-06$ & $1.317 \mathrm{E}-06$ & $1.388 \mathrm{E}-06$ & $5.08 \mathrm{E}-05$ & $3.70 \mathrm{E}-06$ \\
\hline
\end{tabular}

\begin{tabular}{|l|c|}
\hline \multicolumn{1}{|c|}{ Parameter } & Value \\
\hline Power used in the calculation, Watts & 0.0326 \\
\hline $\mathrm{G}\left(\mathrm{H}_{2}\right)$, molecules/100 ev & 1.6 \\
\hline $\begin{array}{l}\text { Hydrogen generation rate obtained using the power, } \\
\text { moles/s }\end{array}$ & $5.415 \mathrm{E}-9$ \\
\hline
\end{tabular}




\section{Results from the spreadsheet}

Using the steady state model, the following results were obtained:

\begin{tabular}{|l|c|}
\hline $\begin{array}{c}\text { Bag number (starting } \\
\text { with the inner bag as } \\
\text { bag 1) }\end{array}$ & $\begin{array}{c}\text { Hydrogen } \\
\text { fraction (steady } \\
\text { state) }\end{array}$ \\
\hline $\mathrm{n}, 8 / \mathrm{n}, \mathrm{t} \quad$ (Drum) & 0.0015 \\
\hline $\mathrm{n}, 7 / \mathrm{n}, \mathrm{T}$ (Liner) & 0.0016 \\
\hline $\mathrm{n}, 6 / \mathrm{n}, \mathrm{T} \mathrm{(bag} \mathrm{6)}$ & 0.0055 \\
\hline $\mathrm{n}, 5 / \mathrm{n}, \mathrm{T}$ (Bag 5) & 0.0096 \\
\hline $\mathrm{n}, 4 / \mathrm{n}, \mathrm{T}$ (Bag 4) & 0.0139 \\
\hline $\mathrm{n}, 3 / \mathrm{N}, \mathrm{T}$ (bag 3) & 0.0185 \\
\hline $\mathrm{n}, 2 / \mathrm{n}, \mathrm{T} \quad$ (Bag 2) & 0.0233 \\
\hline $\mathrm{n}, 1 / \mathrm{n}, \mathrm{T}$ (Inner Bag) & 0.0285 \\
\hline
\end{tabular}

Since in all three cases the hydrogen concentration was well below $4 \%$, the model matches the data from the WIPP TRUCON data. 
CHPRC-01674, Rev. 1

\section{Appendix F}

Attachment from E-Mail Regarding Gram Limit Guidance for Debris Waste Streams 


\section{Appendix F \\ Attachment from E-Mail Regarding Gram Limit Guidance for Debris Waste Streams}

Marusich, Robert $M$

Subject:

FW: Gram Guidance Table

From: Greager, Eric $M$

Sent: Monday, July 18, 2011 11:17 AM

To: Clinton, Richard (Rich)

Cc: Arrenholz, Daniel A; DeRosa, David C; Danna, Marc; Greager, Eric M

Subject: FW: Gram Guidance Table

Rich:

This might be the table you were asking me about last week.

Eric

From: Smith, Kathryn A

Sent: Wednesday, November 19, 2003 1:16 PM

To: Greager, Eric M; Roberts, Kay ]

Cc: Clark, Travis

Subject: Gram Guidance Table

Here's the latest and greatest gram guidance table. Removed days to matrix depletion...

KathrynA. Smith

Scte Transportation Certification Official

(509) 372-3300 


\section{Attachment to Email}

\section{Gram Limit Guidance for Debris Waste Streams}

Note: This information is for guidance only and is not a waste packaging instruction. All waste is to be packaged in accordance with an approved waste profile sheet.

These tables apply only to debris waste streams (RH 125/225 TRUCON Code). This consists of: surgical gloves, plastic bags and sheets, paper products, cloth, tape, rubber, leaded glass, lead-lined hood gloves, lead blankets, light bulbs, flashlight batteries, piping, conduit, wiring, glass and metal portions of gloveboxes, pumps, motors, standard laboratory equipment and various other debris. For questions regarding "debris", contact the TRU Program.

\begin{tabular}{|l|c|c|c|}
\hline Package Configuration & $\begin{array}{c}\text { Gram Limit } \\
\text { Weapons Grade }\end{array}$ & $\begin{array}{c}\text { Gram Limit } \\
\text { Fuel Grade }\end{array}$ & $\begin{array}{c}\text { Gram Limit } \\
\text { Reactor Grade }\end{array}$ \\
\hline 55 Gal Drum 3 Filtered Layers $(0.2634 \mathrm{w})$ & $\mathbf{8 3}$ grams & 36 grams & 25 grams \\
\hline 55 Gal Drum 1 Filtered Layer $(0.3131 \mathrm{w})$ & 99 grams & 40 grams & 28 grams \\
\hline SWB 3 Filtered Layers $\quad(0.6383 \mathrm{w})$ & 198 grams & 84 grams & 58 grams \\
\hline SWB 1 Filtered Layer $\quad(0.9763 \mathrm{w})$ & $325 \mathrm{FGE}$ & 127 grams & 91 grams \\
\hline 55 Gal Drum 3 Non-Filtered Layers $(0.0690 \mathrm{w})$ & 27 grams & 9 grams & 4.5 grams \\
\hline 55 Gal Drum 3 Non-Filtered Layers $(0.0221 \mathrm{w})$ & 6 grams & 3.1 grams & 2.7 grams \\
\hline 55 Gal Drum 6 Non-Filtered Layers $(0.0326 \mathrm{w})$ & 12 grams & 4 grams & 3 grams \\
\hline 55 Gal Drum 6 Non-Filtered Layers $(0.0104 \mathrm{w})$ & 3.1 grams & 1.2 grams & 0.9 gram \\
\hline SWB 3 Filtered Layers Option 2 see note** $(0.9764)$ & 325 FGE* $^{*}$ & 127 grams & 91 grams \\
\hline SWB 1 Filtered Layer Option 2 see note** $(1.3832)$ & 325 FGE $^{*}$ & 200 grams & 135 grams \\
\hline
\end{tabular}

* TRAMPAC limit - Includes actual plus 2 times measurement uncertainty

* * Option 2 Includes 2 filters per inner bag and 4 filters on SWB.

For percentages of Am-241 or Pu-238 greater than those listed below, contact the TRU Program for gram limits. The gram limits will be greatly affected by higher percentages of Am-241 or Pu-238.

Am-241

Weapons Grade: , $\quad 0.16 \%$

Fuel Grade: $\quad 1.46 \%$

Reactor Grade: $\quad 2.45 \%$

\begin{tabular}{ll} 
Pu-238 & \\
\hline Weapons Grade: & $0.01 \%$ \\
Fuel Grade: & $0.15 \%$ \\
Reactor Grade: & $0.27 \%$
\end{tabular}

Reactor Grade: $\quad 0.27 \%$

For waste with only Americium-241 present see below. This table is not to be combined or used with the table above.

\begin{tabular}{|l|c|}
\hline Package Configuration & $\begin{array}{c}\text { Gram Limit } \\
\text { Am-241 Only }\end{array}$ \\
\hline 55 Gal Drum 3 Filtered Layers $(0.2634 \mathrm{w})$ & 2 grams \\
\hline 55 Gal Drum 1 Filtered Layer $(0.3131 \mathrm{w})$ & 2.5 grams \\
\hline SWB 3 Filtered Layers $\quad(0.6383 \mathrm{w})$ & grams \\
\hline SWB 1 Filtered Layer $\quad(0.9764 \mathrm{w})$ & $\mathbf{8 . 4}$ grams \\
\hline 55 Gal Drum 3 Non-Filtered Layers $(0.0637 \mathrm{w})$ & 0.5 gram \\
\hline 55 Gal Drum 3 Non-Filtered Layers $(0.0204 \mathrm{w})$ & 0.15 gram \\
\hline 55 Gal Drum 6 Non-Filtered Layers $(0.0326 \mathrm{w})$ & 0.25 gram \\
\hline 55 Gal Drum 6 Non-Filtered Layers $(0.0104 \mathrm{w})$ & 0.08 gram \\
\hline SWB 3 Filtered Layers Option 2 see note** $(0.9764)$ & 8.4 grams \\
\hline SWB 1 Filtered Layer Option 2 see note** $(1.3832)$ & 11.8 grams \\
\hline
\end{tabular}

** Option 2 Includes 2 filters per inner bag and 4 filters on SWB. 
CHPRC-01674, Rev. 1

This page is intentionally left blank. 
CHPRC-01674, Rev. 1

\section{Appendix G}

\section{Clarification of Data Used by WIPP in the Development of the} TRUCON Code for PTO in SWB 


\section{Appendix G \\ Clarification of Data Used by WIPP in the Development of the TRUCON Code for PTO in SWB}

\section{G.1 Clarification on TRUCON Code Information and Decay Heat}

The following is a series of e-mails sent between Robert Marusich of CHPRC and Various individuals at WIPP (Jennifer Biedscheid and Murthy Devarakonda)

From: Biedscheid, Jennifer - WTS [mailto:Jennifer.Biedscheid@wipp.ws]

Sent: Tuesday, November 29, 2011 10:17 AM

To: Marusich, Robert M

Cc: Rhoades, James - DOE; Brown, Mike - DOE; Sellmer, Todd - WTS; Devarakonda, Murthy - WTS; Sinisa M Djordjevic; Morrison, Cindy - WTS

Subject: WIPP responses to me questions - Need your help in interpreting WIPP TRUCON code data for Hanford

Robert:

Responses to your specific questions (of 11/18/11; clarified on 11/20/11) are provided below (in blue font).

Please let us know if you have additional questions or if any of the responses require clarification.

Thank you,

Jennifer

Jennifer Biedscheid

Advisory Engineer

Washington TRU Solutions LLC

Contractor for the U.S. Department of Energy

Office: 505.878 .1343

Mobile: 505.231 .8228

Facsimile: 505.821 .9341

iennifer.biedscheid@wipp.ws

Question 1: The TRUCON code data made no mention of a liner (Rev 40 of CH-TRUCON for RH-111S/112S). The Pencil Tank Overpacks (PTO) in a Standard Waste Box configuration has a liner in it. Does the TRUCON data include a liner that has openings large enough that the hydrogen concentration in the liner is the same as in the SWB or was it based on no liner being present? If a liner was assumed to be present, what is the diffusivity of the liner. 
Response to Question 1: All CH-TRUCON codes are developed using information provided by the requesting site. The approved packaging configuration description for C H-TRUCON Code RH $111 \mathrm{~S} / 211 \mathrm{~S}$ is based on information provided by Hanford, which did not specify a liner in the SWB. RH $111 \mathrm{~S} / 211 \mathrm{~S}$ payload shipping categories assume no liner is present in the SWB. The confinement layers consist only of the drum liner bag (twist-and-tape closure), the filtered PVC pipe (3.7E-06 mol $/ \mathrm{s} / \mathrm{mf})$, and the SWB $(3.7 \mathrm{E}-05 \mathrm{~mol} / \mathrm{s} / \mathrm{mf}$ total). Correspondence with Eric Greager during the code development process that confirmed the accuracy of the description for RH $111 \mathrm{~S} / 211 \mathrm{~S}$ is attached. I am copying Eric on this message so that any discrepancies can be addressed internally at Hanford.

Question 2: Regarding the plastic bag around the cardboard tube (we call it the sonotube). What diffusivity was used for the plastic bag in the W"IPP development of the TRUCON code? Not having that data, I considered using the WIPP data you sent to me for a "large twist and tape liner bag" - a diffusivity of $4.67 \times 10^{-6}$ moles/s-mole fraction. One could also use the diffusivity of the twist and tape bag from The tests performed in the CH-TRU Payload appendicies, Section 6.8 , Table $6.8-5$ of around $1.054 \mathrm{E}-6 \mathrm{moles} / \mathrm{s}-\mathrm{mole}$ fraction (adding the diffusivity of the bag and the diffusivity of the closure). Which was used in the analysis for the TRUCON code? There are indications that the bag we will use may be in-between the sizes of the bags used in the analysis. How would you accommodate that?

Response to Question 2: Based on the information (bag dimensions) provided by Hanford, a "drum liner bag" (4.67E-06 $\mathrm{mol} / \mathrm{s} / \mathrm{mf}$ as specified in CH-TRU Payload Appendix 2.2) was used in the calculation of payload shipping categories. As stated above, the generator site information is used in the development of the $\mathrm{CH}_{-}$ TRUCON code and resulting shipping category. If there are any discrepancies in the packaging description provided by Hanford (versus the information being presented now), these need to be resolved internally at Hanford and a new code requested if applicable.

Regarding the hypothetical question as to how bag sizes in between those defined in the CH-TRU Payload Appendices are addressed, the lower diffusivity value is used. Note that any site-specific analyses Hanford is performing can presumably use actual values.

Question 3: Do the equations for WIPP use as an maximum allowable $\mathrm{H} 2$ concentration within package of $4 \%$ hydrogen or $5 \%$ hydrogen?

Response to Question 3: The NRC requirements specify a limit of 5\% hydrogen concentration in all regions of the payload/package. If flammable volatile organic compounds are present in concentrations greater than 500 $\mathrm{ppm}$, the allowed hydrogen concentration is proportionately reduced to keep the concentrations of the mixture below a mixture lower explosive limit.

Question 4: . For TRUCON code RH 111S/112S, how many PTOs were assumed to be in the standard waste box? I assume that since the TRUCON code does not have any gram load limits, the limit is the standard value for SWBs ( $325 \mathrm{~g})$.

Response to Question 4: As stated in the CH-TRUCON document, CH-TRUCON Code RH 111/211S assumes up to six pencil tank overpacks per standard waste box. The CH-TRUCON code does have gram loading limits in the form of a decay heat limit. A decay heat limit (of 0.3915 watt) is associated with the payload shipping category $(1001600077)$ for RH 111/211S. Compliance with this decay heat limit per SWB is required in addition to the $325 \mathrm{~g}$ fissile gram equivalent limit per SWB. Based on the decay heat limit and assuming weapons-grade plutonium, you cannot put $325 \mathrm{~g}$ FGE per PTO. However, if hydrogen is measured in the SWB headspace and found to be low, higher FGE quantities (exceeding the decay heat limit) per SWB may be compliant. (See clarification on next page). 


\section{CHPRC-01674, Rev. 1}

From: Marusich, Robert M [mailto:Robert M Marusich@RL.gov]

Sent: Tuesday, January 10, 2012 12:20 PM

To: Biedscheid, Jennifer - WTS

Cc: Marusich, Robert M

Subject: A clarification, please on the Hanford calculation of hydrogen in waste packages.

\section{First Question that needs clarification:}

You replied, below, that there is a decay heat limit besides a gram limit. The decay heat limit was 0.3915 W. Is this limit a "per PTO" limit or an "SWB-as-a-whole" limit?

Reply from Murthy Devarakonda:: The decay heat limit is per SWB (not per pencil tank overpack-several pencil tank overpacks may be present per SWB).

\section{Second question that needs clarification:}

In my calculations, using fuels grade $\mathrm{Pu}$, I get that $0.3915 \mathrm{~W}$ is equal to about $60 \mathrm{~g}$. If the decay heat limit is an SWB limit, then one could only put $60 \mathrm{~g}$ in an SWB.

Reply from Murthy Devarakonda: : Concluding that the decay heat limit will limit the gram loading of the SWB to $60 \mathrm{~g}$ is incorrect - as discussed during our phone call a few months back, the decay heat limit can be exceeded if SWB headspace hydrogen gas measurement shows that the flammable gas generation rate is below the limit (calculation done in the WDS software). Headspace measurement is a valid, viable, and approved compliance methodology and has been used to qualify several thousand containers (including containers from Hanford) that have already been shipped to WIPP.

Bob Marusich

Safety Analysis Group

376-8081

Pager 85-7426

PFP, MO-273, Room C-108 


\section{G.2 Clarification -Sonotube Bag Size and Diffusivity}

Morrison, Cindy - WTS

$\begin{array}{ll}\text { From: } & \text { Biedscheid, Jennifer - WTS } \\ \text { Sent: } & \text { Monday, December 06, 2010 11:06 AM } \\ \text { To: } & \text { Morrison, Cindy - WTS } \\ \text { Subject: } & \text { FW: TRUCON request Attachment, TRUCON Request }\end{array}$

Jennifer Biedscheid

Advisory Engineer

Washington TRU Solutions LLC

Contractor for the U.S. Department of Energy

Office: 505.878 .1343

Mobile: 505.231 .8228

Facsimile: 505.821 .9341

Jennifer.biedscheid@wipp.ws

-.--Original Message-....

From: Greager, Eric M [mailto:Eric_M_Greager@RL.gov]

Sent: Thursday, December 02, $2010 \quad 4: 19$ PM

To: Biedscheid, Jennifer - WTS

Cc: North, Amanda - WTS; Reeves, Ron; DeRosa, David C; Greager, Eric M

Subject: RE: TRUCON request Attachment, TRUCON Request

Jennifer:

I received the calculations from PFP today on the surface area of the plastic bags that contain the cardboard sonotubes in the pencil tank overpacks. For the longer bags, the calculation comes out to 3975 square inches ( 2.56 square meters) and the shorter bags come to 3405 square inches ( 2.2 square meters). So, it looks like both bags exceed the threshold of 1.6 square meters to qualify as a drum liner bag.

Eric

-.---Original Message-....

From: Biedscheid, Jennifer - WTS [mailto:Jennifer.Bledscheid@wipp.ws]

Sent: Tuesday, November 30, 2010 10:18 AM

To: Greager, Eric M

Cc: North, Amanda - WTS; Reeves, Ronald D; DeRosa, David C

Subject: RE: TRUCON request Attachment, TRUCON Request

Eric:

Do you know the dimensions of the bagout bag that is horsetailed closed around the sonotube? If it has an avallable surface area of $1.6 \mathrm{~m} 2$ or greater, it could be considered a drum liner bag (which has a greater hydrogen release rate than an inner bag; although, as you know, the filtered bag would have the highest release rate of all bag types).

Thank you,

Jennifer

Jennifer Biedscheid

Advisory Engineer 
CHPRC-01674, Rev. 1

\section{Appendix $\mathbf{H}$}

\section{Equations Shown in the Spreadsheet}




\section{Appendix $\mathrm{H}$ \\ Equations Shown in the Spreadsheet}

With the exception of a few variables, the "variable names" (the variables are in Column A) are obvious. The ones that are not are defined below.

\begin{tabular}{|l|l|l|}
\hline \multicolumn{1}{|c|}{ Cell } & \multicolumn{1}{|c|}{ Variable } & \multicolumn{1}{c|}{ Definition } \\
\hline A35 & n,5/N,T & Mass fraction in the SWB. \\
\hline A36 & n,4/N,T & Mass fraction in the SWB Liner. \\
\hline A37 & n,3/N,T & Mass fraction in the PTO. \\
\hline A38 & n,2/N,T & Mass fraction in the bag around the sonotube. \\
\hline A39 & n,1/N,T & Mass fraction within the sonotube. \\
\hline E29 & watts & Input value - the watts in the waste package. \\
\hline A26 & $\begin{array}{l}\text { Grams plutonium in inner } \\
\text { package }\end{array}$ & Grams plutonium in the sonotube. \\
\hline H24- H29 & grams & $\begin{array}{l}\text { Reading down, the values are the grams of that plutonium (or } \\
\text { americium) isotope in a gram of plutonium mix (Cell D25). }\end{array}$ \\
\hline I24- I29- & Ci/gram & $\begin{array}{l}\text { Reading down, these are the values for specific activity for the } \\
\text { plutonium and americium isotopes. }\end{array}$ \\
\hline J24-J29 & Curies & $\begin{array}{l}\text { Reading down, these are the values of the curies of the plutonium } \\
\text { and americium isotopes in a gram of the plutonium mix. }\end{array}$ \\
\hline K24-K29 & Mev/dis & $\begin{array}{l}\text { Reading down, the values are the energy of the radiation given } \\
\text { off by the plutonium (or americium) isotope. }\end{array}$ \\
\hline D28 andN31 & Average Mev & $\begin{array}{l}\text { I29 is the average energy of the radiation given off by the } \\
\text { mixture of plutonium and americium isotopes. }\end{array}$ \\
\hline J31 & Total minus ${ }^{241}$ Pu & $\begin{array}{l}\text { Cell H38 provides the curies per gram of the alpha emitting } \\
\text { isotopes in the plutonium and americium mix. }\end{array}$ \\
\hline
\end{tabular}

The next page shows the layout of the spreadsheet. The three pages after that show the equations used for each cell within the spreadsheet. 
CHPRC-01674, Rev. 1

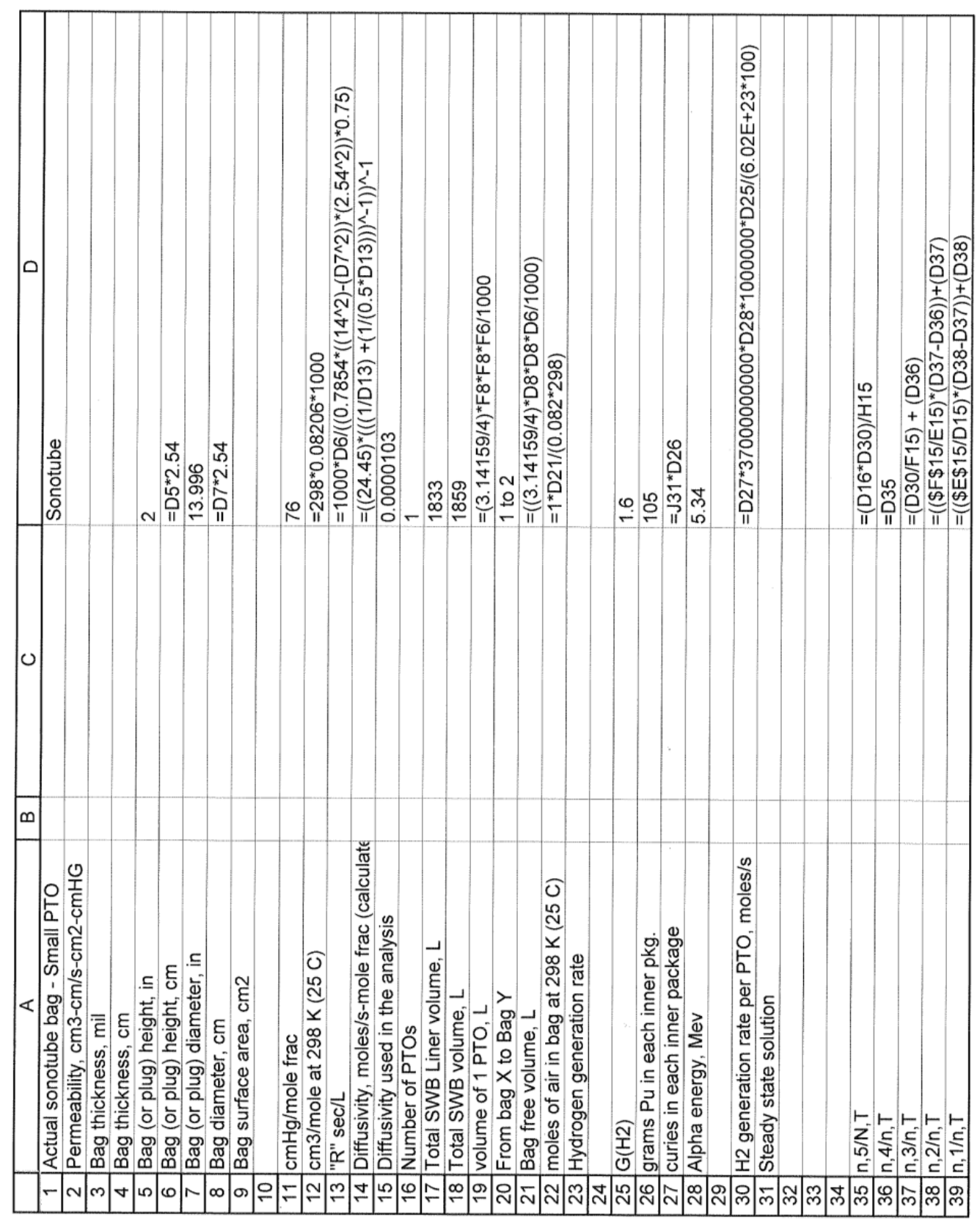


CHPRC-01674, Rev. 1

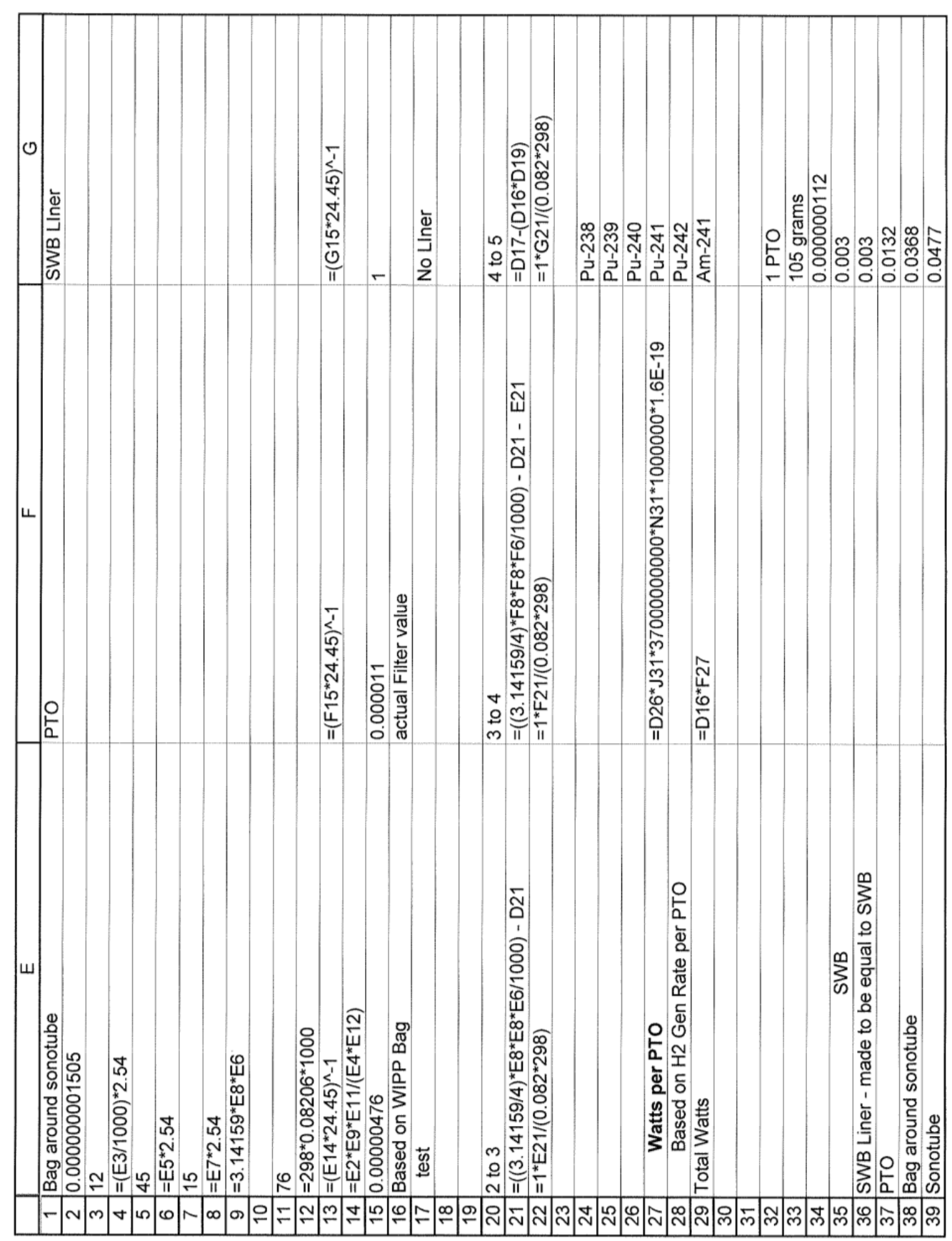


CHPRC-01674, Rev. 1

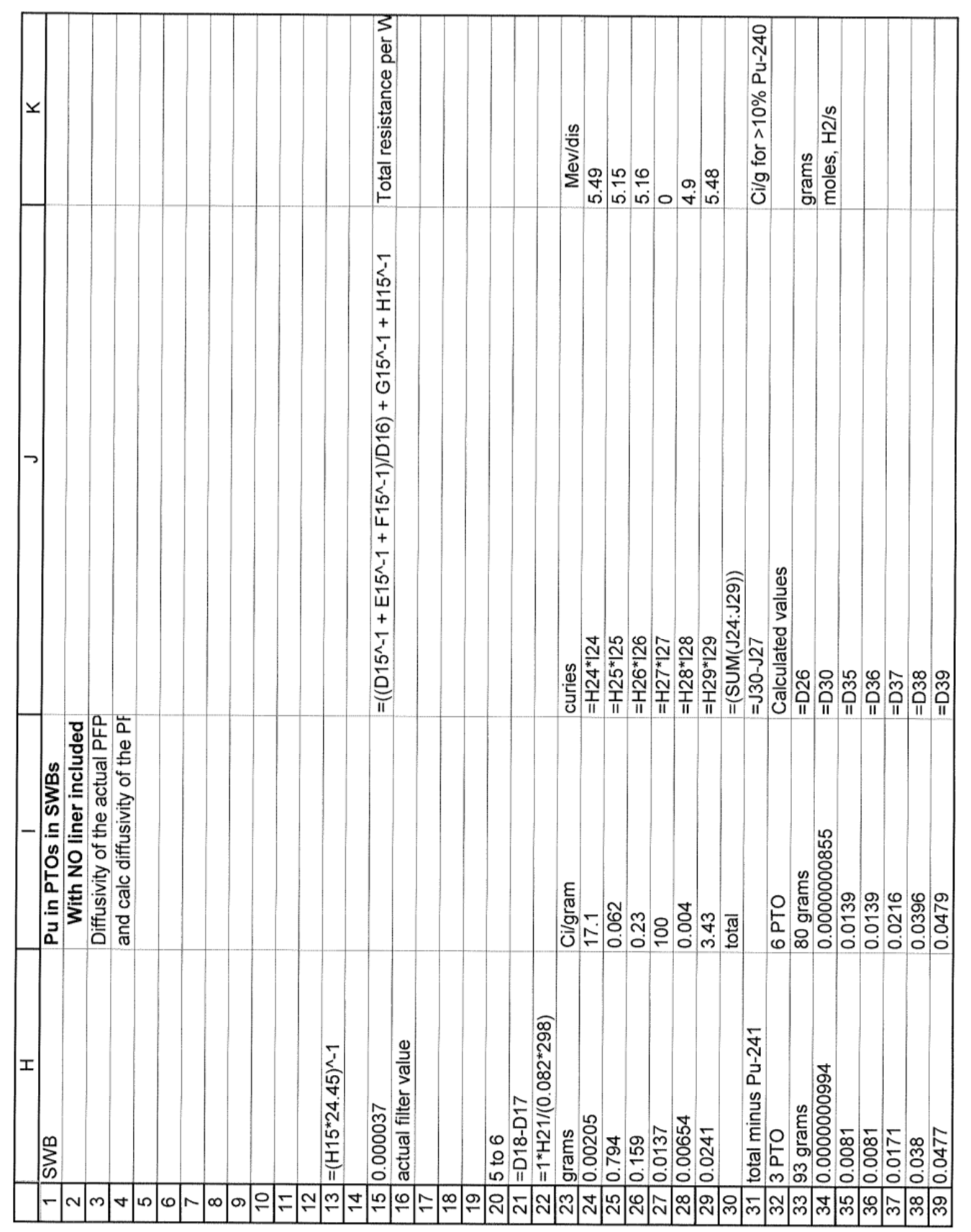


CHPRC-01674, Rev. 1

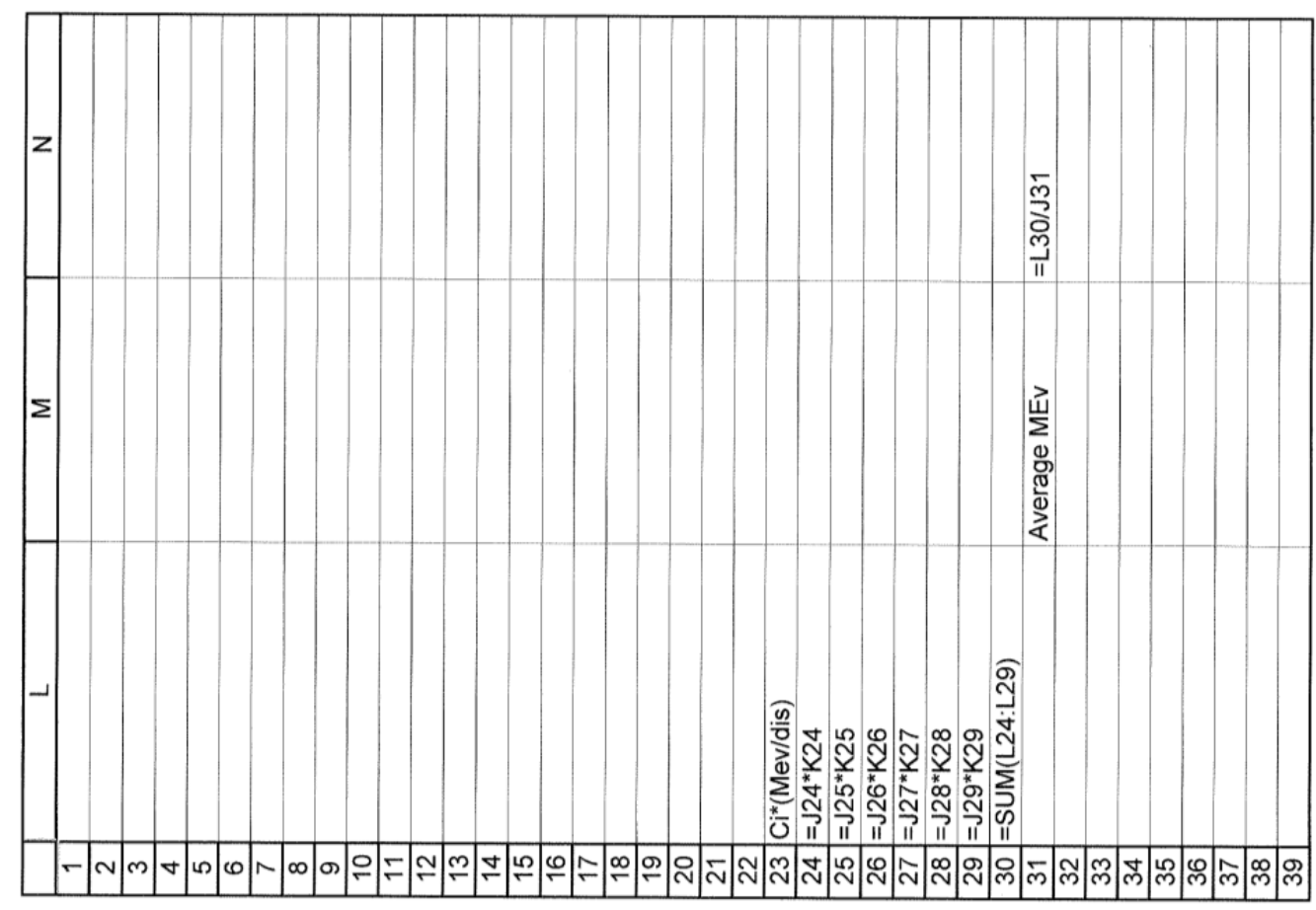


CHPRC-01674, Rev. 1

\section{Appendix I}

\section{Peer Review Sheet}




\section{Appendix I \\ Peer Review Sheet}

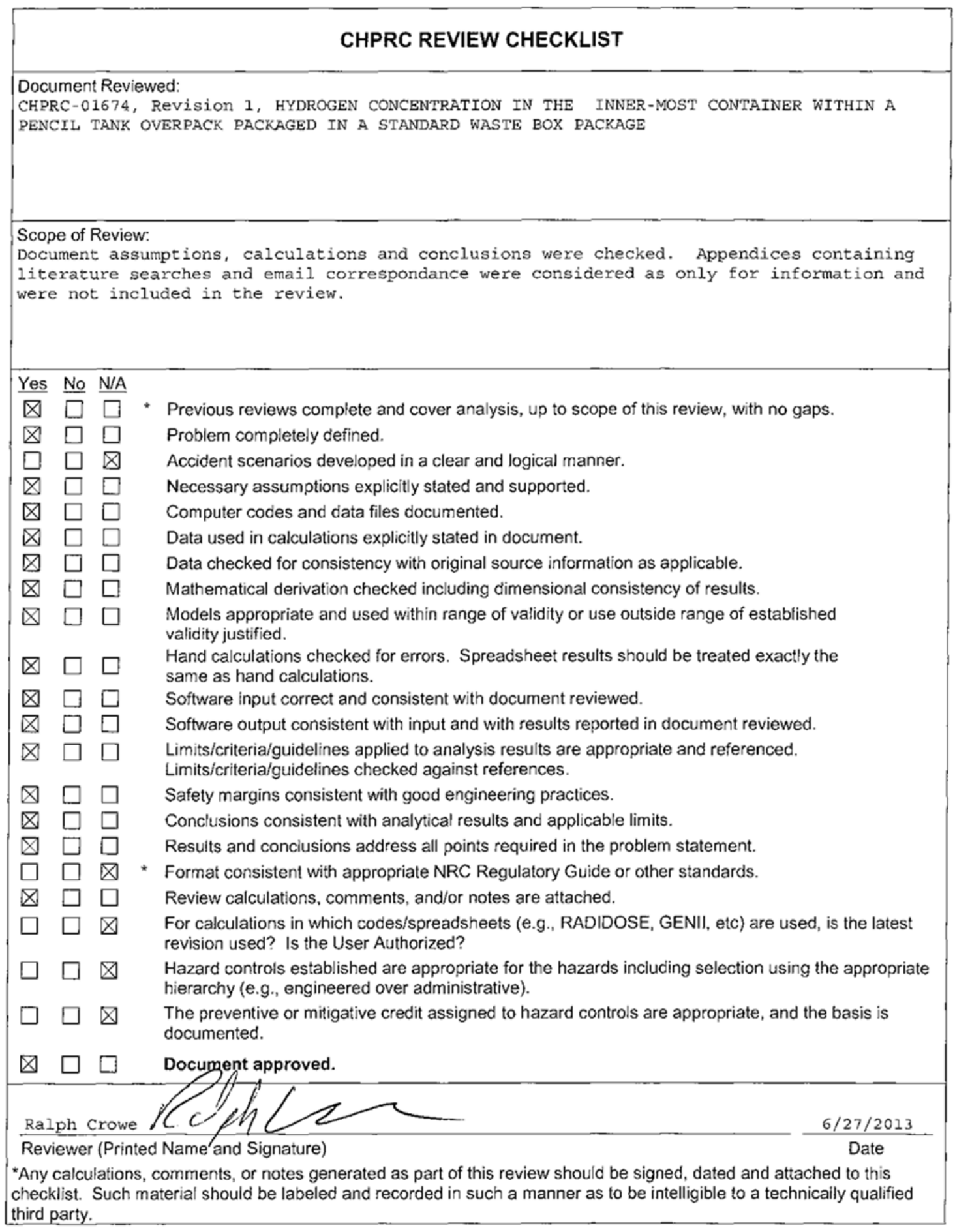


$\mathrm{cm} \_\mathrm{Hg} \equiv \frac{\mathrm{cm}}{\text { in }} \cdot$ in_Hg

$\mathrm{atm}=76 \cdot \mathrm{cm} \_\mathrm{Hg}$

$\operatorname{mol}_{\mathrm{frac}}:=\mathrm{atm}$

molecule $\equiv 1$

dis $\equiv 1$

$\mathrm{ev} \equiv 1.6021757 \cdot 10^{-19} \cdot$ joule

$\mathrm{Mev} \equiv 10^{6} \mathrm{ev}$

$\mathrm{Ci} \equiv 3.7 \cdot 10^{10} \cdot \frac{\mathrm{dis}}{\mathrm{s}}$

$\mathrm{N}_{\mathrm{A}}:=6.02 \cdot 10^{23} \cdot \frac{\text { molecule }}{\text { mole }}$

$\mathrm{R}_{\mathrm{gas}} \equiv 0.08205746 \cdot \frac{\mathrm{L} \cdot \mathrm{atm}}{\mathrm{K} \cdot \mathrm{mole}}$

$\mathrm{P}_{\mathrm{STP}}:=1 \cdot \mathrm{atm} \quad \mathrm{T}_{\mathrm{STP}}:=298 \cdot \mathrm{K}$

$\mathrm{C}_{\mathrm{mol}}:=\frac{\mathrm{atm}}{\left(\mathrm{R}_{\text {gas }}{ }^{\mathrm{T}} \mathrm{STP}\right)}$

\subsection{Hydrogen Generation Rate}

Calculated from PFP Pu $\quad \mathrm{Mev}_{\mathrm{dis}}:=5.34 \cdot \frac{\mathrm{Mev}}{\mathrm{dis}}$
inventory

$\mathrm{Pu}_{\text {mass }}:=250 \cdot \mathrm{gm}$

$\mathrm{Ci}_{\text {total }}:=\mathrm{Pu}_{\text {mass }} \cdot \mathrm{Ci}_{\mathrm{g} . \mathrm{Pu}}=50.9 \cdot \mathrm{Ci}$

$$
\begin{aligned}
& \mathrm{n}_{\mathrm{H} 2}\left(\mathrm{~N}_{\mathrm{H} 2}, \mathrm{~L}_{\mathrm{r}}, \mathrm{L}_{\mathrm{L}}, \mathrm{L}_{\mathrm{D}}\right):=\mid \begin{array}{l}
\mathrm{n}_{8} \leftarrow \frac{\mathrm{N}_{\mathrm{H} 2}}{\mathrm{~L}_{\mathrm{D}} \cdot \mathrm{atm}} \\
\mathrm{n}_{7} \leftarrow \frac{\mathrm{L}_{\mathrm{D}}}{\mathrm{L}_{\mathrm{L}}} \cdot \mathrm{n}_{8}+\mathrm{n}_{8}
\end{array} \\
& \mathrm{n}_{6} \leftarrow \frac{\mathrm{L}_{\mathrm{L}}}{\mathrm{L}_{\mathrm{r}_{0,5}}} \cdot\left(\mathrm{n}_{7}-\mathrm{n}_{8}\right)+\mathrm{n}_{7} \\
& \mathrm{n}_{5} \leftarrow \frac{\mathrm{L}_{\mathrm{r}_{0,5}}}{\mathrm{~L}_{\mathrm{r}_{0,4}}} \cdot\left(\mathrm{n}_{6}-\mathrm{n}_{7}\right)+\mathrm{n}_{6} \\
& \mathrm{n}_{4} \leftarrow \frac{\mathrm{L}_{0,4}}{\mathrm{~L}_{\mathrm{r}_{0,3}}} \cdot\left(\mathrm{n}_{5}-\mathrm{n}_{6}\right)+\mathrm{n}_{5} \\
& \mathrm{n}_{3} \leftarrow \frac{\mathrm{L}_{\mathrm{r}_{0,3}}}{\mathrm{~L}_{\mathrm{r}_{0,2}}} \cdot\left(\mathrm{n}_{4}-\mathrm{n}_{5}\right)+\mathrm{n}_{4} \\
& \mathrm{n}_{2} \leftarrow \frac{\mathrm{L}_{\mathrm{r}_{0,2}}}{\mathrm{~L}_{\mathrm{r}_{0,1}}} \cdot\left(\mathrm{n}_{3}-\mathrm{n}_{4}\right)+\mathrm{n}_{3} \\
& \mathrm{n}_{1} \leftarrow \frac{\mathrm{L}_{\mathrm{r}_{0,1}}}{\mathrm{~L}_{\mathrm{r}_{0,0}}} \cdot\left(\mathrm{n}_{2}-\mathrm{n}_{3}\right)+\mathrm{n}_{2}
\end{aligned}
$$

$$
\mathrm{Ci}_{\mathrm{g} . \mathrm{Pu}}:=0.2035 \cdot \frac{\mathrm{Ci}}{\mathrm{gm}}
$$

$$
\begin{gathered}
\mathrm{Pu}_{\text {mass }} \cdot \mathrm{Ci}_{\mathrm{g} \cdot \mathrm{Pu}} \cdot \mathrm{Mev}_{\text {dis }}=1.61 \mathrm{~W} \\
\mathrm{Pu}_{\text {mass }} \cdot 0.0064 \frac{\mathrm{watt}}{\mathrm{gm}}=1.6 \mathrm{~W}
\end{gathered}
$$

$\mathrm{G}_{\mathrm{H} 2}:=0.4 \cdot \frac{\text { molecule }}{100 \mathrm{ev}}$

$$
\mathrm{N}_{\mathrm{H} 2}:=\frac{\mathrm{Ci}_{\text {total }} \cdot \mathrm{Mev}_{\mathrm{dis}} \cdot \mathrm{G}_{\mathrm{H} 2}}{\mathrm{~N}_{\mathrm{A}}}=6.7 \times 10^{-8} \frac{\mathrm{mol}}{\mathrm{s}} \quad \mathrm{N}_{\mathrm{H} 2} \cdot \frac{\mathrm{R}_{\mathrm{gas}} \cdot \mathrm{T}_{\mathrm{STP}}}{\mathrm{P}_{\mathrm{STP}}}=5.9 \cdot \frac{\mathrm{mL}}{\mathrm{hr}}
$$

$\mathrm{G}_{\mathrm{H} 2}:=1.6 \cdot \frac{\text { molecule }}{100 \mathrm{ev}}$ 


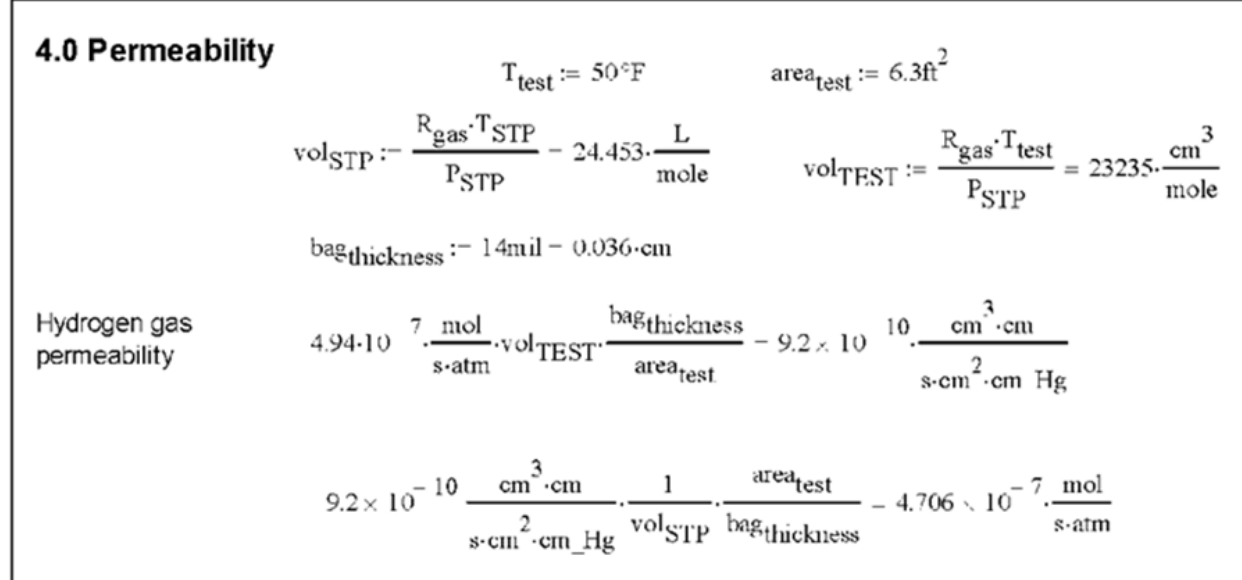

\subsection{Permeability of "Horse-Tailed" Closures}

$$
\text { area }_{\text {test }}:^{-}+710 \cdot \mathrm{cm}^{2} \quad \text { bag }_{\text {thickness }}-0.036 \cdot \mathrm{cm}
$$

$$
\begin{array}{lll}
\begin{array}{l}
\text { Hydrogen gas } \\
\text { permeability }
\end{array} & 1.71 \cdot 10^{-7} \cdot \frac{\mathrm{mol}}{\mathrm{s} \cdot \mathrm{atm}} \cdot \mathrm{vol}_{\mathrm{STP}} \cdot \frac{14 \mathrm{mil}}{\text { area }_{\text {test }}}=2.8,10^{-9} \cdot \frac{\mathrm{cm}^{3} \cdot \mathrm{cm}}{\mathrm{s} \cdot \mathrm{cm}^{2} \cdot \mathrm{cm}_{-} \mathrm{Hg}} & \text { Appendix B } \\
& 2.32 \cdot 10^{7} \cdot \frac{\mathrm{mol}}{\mathrm{s} \cdot \mathrm{atm}} \cdot \mathrm{vol}_{\mathrm{STP}} \cdot \frac{G_{\text {amil }}}{\text { area }_{\text {test }}}-1.6,10^{9} \frac{9 \mathrm{~cm}^{3} \cdot \mathrm{cm}}{\mathrm{s} \cdot \mathrm{cm}^{2} \cdot \mathrm{cm} \mathrm{Hg}} & \text { Appendix B }
\end{array}
$$

\subsubsection{Sonotube gap resistance}

$$
\begin{aligned}
& \text { Sonotube } \\
& \mathrm{D}:=11 \mathrm{in} \quad \text { diffusivity of } \\
& \text { diameter } \\
& \text { hydrogen } \\
& \text { Diff } I 12:=0.75 \cdot \frac{\mathrm{cm}^{2}}{\mathrm{~s}} \\
& \text { length of cushion flow path } x_{\text {cushion }}:=2 \text {-in } \\
& \text { length of plug flow path } \\
& \mathrm{x}_{\text {plug }}:=1 \cdot 0 \cdot \mathrm{in} \\
& \text { gap }_{\text {cushion }}:=2 \mathrm{mil} \\
& \text { Diff }_{\text {sonotube }}:=\left(\frac{1}{\mathrm{R}_{\text {cushion }}}, \frac{1}{\mathrm{R}_{\text {plug }}}\right) \cdot \frac{1}{\left(\mathrm{rol}_{\mathrm{STP}} \cdot \mathrm{atm}\right)}=1, \mathrm{in} 8 \mathrm{x} \times 10^{-5} \cdot \frac{\mathrm{mol}}{\mathrm{s} \cdot \mathrm{mol}_{\mathrm{frac}}} \\
& \mathrm{R}_{\text {cushion }}:=\frac{\mathrm{x}_{\text {cushion }}}{\frac{\pi}{4} \cdot\left[D^{2}-\left(D-2 \mathrm{gap}_{\text {cushion }}\right)^{2}\right] \cdot \mathrm{Diff} H 2}=1195 \cdot \frac{\mathrm{s}}{\mathrm{L}} \quad \mathrm{R}_{\text {plug }}:=\frac{\mathrm{x}_{\text {plug }}}{\frac{\pi}{4} \cdot\left[D^{2}-\left(\mathrm{D}-2 \mathrm{gap}_{\text {plug }}\right)^{2}\right] \cdot \mathrm{Diff}_{\mathrm{H} 2}}=598 \cdot \frac{\mathrm{s}}{\mathrm{L}}
\end{aligned}
$$



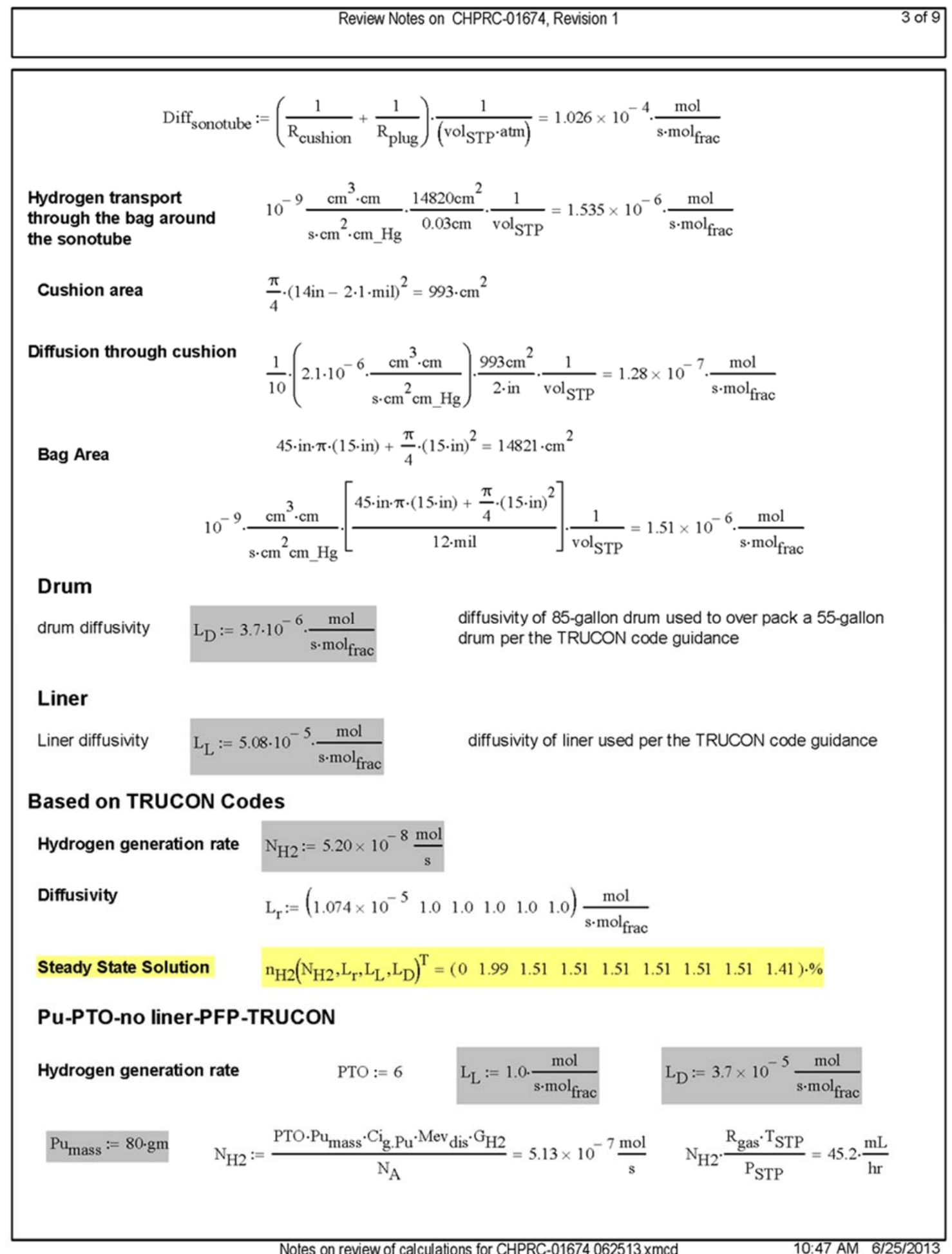


$$
\begin{aligned}
& \text { Diffusivity } \quad \mathrm{L}_{\mathrm{r}}:=\left(\mathrm{PTO} \cdot 1.0 \cdot 10^{-5} \mathrm{PTO} \cdot 4.67 \times 10^{-6} \mathrm{PTO} \cdot 1.1 \cdot 10^{-5} 1.0 \quad 1.0 \quad 1.0\right) \frac{\mathrm{mol}}{\mathrm{s} \cdot \mathrm{mol}_{\mathrm{frac}}} \\
& \text { Steady State Solution } \quad \mathrm{n}_{\mathrm{H} 2}\left(\mathrm{~N}_{\mathrm{H} 2}, \mathrm{~L}_{\mathrm{r}}, \mathrm{L}_{\mathrm{L}}, \mathrm{L}_{\mathrm{D}}\right)^{\mathrm{T}}=\left(\begin{array}{lllllllll}
0 & 4.85 & 3.99 & 2.16 & 1.39 & 1.39 & 1.39 & 1.39 & 1.39
\end{array}\right) \cdot \% \\
& \mathrm{~L}_{\mathrm{L}}:=1 \cdot 0 \cdot \frac{\mathrm{mol}}{\mathrm{s} \cdot \mathrm{mol}_{\mathrm{frac}}} \\
& \mathrm{L}_{\mathrm{D}}:=3.7 \times 10^{-5} \frac{\mathrm{mol}}{\mathrm{s} \cdot \mathrm{mol}_{\mathrm{frac}}} \\
& \mathrm{L}_{\mathrm{r}}(\mathrm{PTO}):=\left(\text { PTO } \cdot 1.03 \times 10^{-5} \text { PTO } 4.67 \times 10^{-6} \text { PTO } 1.1 \times 10^{-5} 1.01 .01 .0\right) \frac{\mathrm{mol}}{\mathrm{s} \cdot \mathrm{mol}_{\mathrm{frac}}}
\end{aligned}
$$

PTO := 6 Pumass $:=80 \cdot \mathrm{gm}$

$$
\mathrm{N}_{\mathrm{H} 2}:=\frac{\mathrm{PTO} \cdot \mathrm{Pu}_{\text {mass }} \cdot \mathrm{Ci}_{\mathrm{g} \cdot \mathrm{Pu}} \cdot \mathrm{Mev}_{\mathrm{dis}} \cdot \mathrm{G}_{\mathrm{H} 2}}{\mathrm{~N}_{\mathrm{A}}}=5.13 \times 10^{-7} \frac{\mathrm{mol}}{\mathrm{s}} \quad \mathrm{PTO} \cdot \mathrm{Pu}_{\text {mass }} \cdot 0.0064 \frac{\text { watt }}{\mathrm{gm}}=3.07 \mathrm{~W}
$$

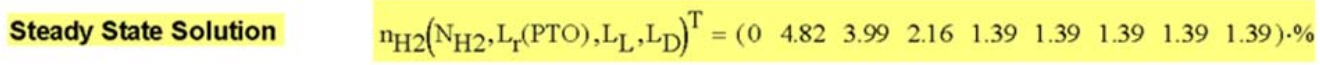

$$
\text { PTO }:=3 \quad \mathrm{Pu}_{\text {mass }}:=93 \cdot \mathrm{gm} \quad \mathrm{N}_{\mathrm{H} 2}:=\frac{\mathrm{PTO} \cdot \mathrm{Pu}_{\text {mass }} \cdot \mathrm{Ci}_{\mathrm{g} . \mathrm{Pu}} \cdot \mathrm{Mev}_{\mathrm{dis}} \cdot \mathrm{G}_{\mathrm{H} 2}}{\mathrm{~N}_{\mathrm{A}}}=2.98 \times 10^{-7} \frac{\mathrm{mol}}{\mathrm{s}}
$$

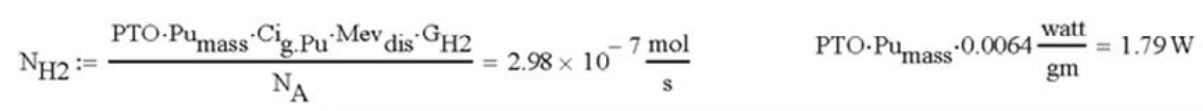

Steady State Solution

PTO $:=1 \quad$ Pumass $:=105 \cdot \mathrm{gm}$

$$
\mathrm{N}_{\mathrm{H} 2}:=\frac{\text { PTO } \cdot \mathrm{Pu}_{\text {mass }} \cdot \mathrm{Ci}_{\mathrm{g} \cdot \mathrm{Pu}} \cdot \mathrm{Mev}_{\mathrm{dis}} \cdot \mathrm{G}_{\mathrm{H} 2}}{\mathrm{~N}_{\mathrm{A}}}=1.12 \times 10^{-7} \frac{\mathrm{mol}}{\mathrm{s}} \quad \text { PTO } \cdot \mathrm{Pu}_{\text {mass }} \cdot 0.0064 \frac{\text { watt }}{\mathrm{gm}}=0.67 \mathrm{~W}
$$

Steady State Solution

$$
\mathrm{n}_{\mathrm{H} 2}\left(\mathrm{~N}_{\mathrm{H} 2}, \mathrm{~L}_{\mathrm{r}}(\mathrm{PTO}), \mathrm{L}_{\mathrm{L}}, \mathrm{L}_{\mathrm{D}}\right)^{\mathrm{T}}=\left(\begin{array}{lllllllll}
0 & 4.82 & 3.73 & 1.32 & 0.3 & 0.3 & 0.3 & 0.3 & 0.3
\end{array}\right) \cdot \%
$$

$$
\text { Pu-PTO-PFP-bag filter-no liner } \quad \mathrm{L}_{\mathrm{L}}:=1.0 \cdot \frac{\mathrm{mol}}{\mathrm{s} \cdot \mathrm{mol}_{\mathrm{frac}}} \quad \mathrm{L}_{\mathrm{D}}:=3.7 \times 10^{-5} \frac{\mathrm{mol}}{\mathrm{s} \cdot \mathrm{mol}_{\mathrm{frac}}}
$$

Diffusivity

$$
\text { PTO }:=6 \quad \mathrm{Pu}_{\text {mass }}:=125 \cdot \mathrm{gm}
$$

$$
\mathrm{N}_{\mathrm{H} 2}:=\frac{\text { PTO } \cdot \mathrm{Pu}_{\text {mass }} \cdot \mathrm{Ci}_{\mathrm{g} . P u} \cdot \mathrm{Mev}_{\mathrm{dis}} \cdot \mathrm{G}_{\mathrm{H} 2}}{\mathrm{~N}_{\mathrm{A}}}=8.01 \times 10^{-7} \frac{\mathrm{mol}}{\mathrm{s}} \quad \text { PTO } \cdot \mathrm{Pu}_{\text {mass }} \cdot 0.0064 \frac{\mathrm{watt}}{\mathrm{gm}}=4.8 \mathrm{~W}
$$

Steady State Solution $\quad \mathrm{n}_{\mathrm{H} 2}\left(\mathrm{~N}_{\mathrm{H} 2}, \mathrm{~L}_{\mathrm{r}}(\mathrm{PTO}), \mathrm{L}_{\mathrm{L}}, \mathrm{L}_{\mathrm{D}}\right)^{\mathrm{T}}=\left(\begin{array}{lllllllll}0 & 4.8 & 3.5 & 3.38 & 2.17 & 2.17 & 2.17 & 2.17 & 2.17\end{array}\right) \cdot \%$ 
PTO $:=3 \quad \mathrm{Pu}_{\text {mass }}:=161 \cdot \mathrm{gm} \quad \mathrm{N}_{\mathrm{H} 2}:=\frac{\mathrm{PTO} \cdot \mathrm{Pu}_{\text {mass }} \cdot \mathrm{Ci}_{\mathrm{g} . \mathrm{Pu}} \cdot \mathrm{Mev}_{\mathrm{dis}} \cdot \mathrm{G}_{\mathrm{H} 2}}{\mathrm{~N}_{\mathrm{A}}}=5.16 \times 10^{-7} \frac{\mathrm{mol}}{\mathrm{s}}$

$\mathrm{N}_{\mathrm{H} 2}:=\frac{\mathrm{PTO} \cdot \mathrm{Pu}_{\text {mass }} \cdot \mathrm{Ci}_{\mathrm{g} \cdot \mathrm{Pu} \cdot \mathrm{Mev}_{\mathrm{dis}} \cdot \mathrm{G}_{\mathrm{H} 2}}}{\mathrm{~N}_{\mathrm{A}}}=5.16 \times 10^{-7} \frac{\mathrm{mol}}{\mathrm{s}} \quad \mathrm{PTO} \cdot \mathrm{Pu}_{\text {mass }} \cdot 0.0064 \frac{\mathrm{watt}}{\mathrm{gm}}=3.09 \mathrm{~W}$

Steady State Solution $\quad \quad \mathrm{n}_{\mathrm{H} 2}\left(\mathrm{~N}_{\mathrm{H} 2}, \mathrm{~L}_{\mathrm{r}}(\mathrm{PTO}), \mathrm{L}_{\mathrm{L}}, \mathrm{L}_{\mathrm{D}}\right)^{\mathrm{T}}=\left(\begin{array}{lllllllll}0 & 4.79 & 3.12 & 2.96 & 1.4 & 1.4 & 1.4 & 1.4 & 1.4\end{array}\right) \cdot \%$

PTO $:=1 \quad \mathrm{Pu}_{\text {mass }}:=200 \cdot \mathrm{gm} \quad \mathrm{N}_{\mathrm{H} 2}:=\frac{\text { PTO } \cdot \mathrm{Pu}_{\text {mass }} \cdot \mathrm{Ci}_{\mathrm{g} \cdot \mathrm{Pu}} \cdot \mathrm{Mev}_{\mathrm{dis}} \cdot \mathrm{G}_{\mathrm{H} 2}}{\mathrm{~N}_{\mathrm{A}}}=2.14 \times 10^{-7} \frac{\mathrm{mol}}{\mathrm{s}}$

$\mathrm{N}_{\mathrm{H} 2}:=\frac{\text { PTO } \cdot \mathrm{Pu}_{\text {mass }} \cdot \mathrm{Ci}_{\mathrm{g} . \mathrm{Pu}} \cdot \mathrm{Mev}_{\mathrm{dis}} \cdot \mathrm{G}_{\mathrm{H} 2}}{\mathrm{~N}_{\mathrm{A}}}=2.14 \times 10^{-7} \frac{\mathrm{mol}}{\mathrm{s}} \quad$ PTO $\cdot \mathrm{Pu}_{\text {mass }} \cdot 0.0064 \frac{\text { watt }}{\mathrm{gm}}=1.28 \mathrm{~W}$

$\mathrm{n}_{\mathrm{H} 2}\left(\mathrm{~N}_{\mathrm{H} 2}, \mathrm{~L}_{\mathrm{r}}(\mathrm{PTO}), \mathrm{L}_{\mathrm{L}}, \mathrm{L}_{\mathrm{D}}\right)^{\mathrm{T}}=\left(\begin{array}{lllllllll}0 & 4.79 & 2.72 & 2.52 & 0.58 & 0.58 & 0.58 & 0.58 & 0.58\end{array}\right) \cdot \%$

Pu-PTO-PFP-actual bag-liner $\quad \mathrm{L}_{\mathrm{L}}:=1.18 \cdot 10^{-4} \cdot \frac{\mathrm{mol}}{\mathrm{s} \cdot \mathrm{mol}_{\mathrm{frac}}} \quad \mathrm{L}_{\mathrm{D}}:=3.7 \times 10^{-5} \frac{\mathrm{mol}}{\mathrm{s} \cdot \mathrm{mol}_{\mathrm{frac}}}$

Diffusivity $\quad \mathrm{L}_{\mathrm{r}}(\mathrm{PTO}):=\left(\mathrm{PTO} \cdot 1.03 \times 10^{-5} \mathrm{PTO} \cdot 4.67 \times 10^{-6} \mathrm{PTO} \cdot 1.1 \times 10^{-5} 1.01 .01 .0\right) \frac{\mathrm{mol}}{\mathrm{s} \cdot \mathrm{mol}_{\mathrm{frac}}}$

PTO $:=6 \quad P u_{\text {mass }}:=80 \cdot \mathrm{gm}$

$\mathrm{N}_{\mathrm{H} 2}:=\frac{\text { PTO } \cdot \mathrm{Pu}_{\text {mass }} \cdot \mathrm{Ci}_{\mathrm{g} \cdot \mathrm{Pu}} \cdot \mathrm{Mev}_{\mathrm{dis}} \cdot \mathrm{G}_{\mathrm{H} 2}}{\mathrm{~N}_{\mathrm{A}}}=$, PTO $\cdot \mathrm{Pu}_{\text {mass }} \cdot 0.0064 \frac{\text { watt }}{\mathrm{gm}}=3.07 \mathrm{~W}$

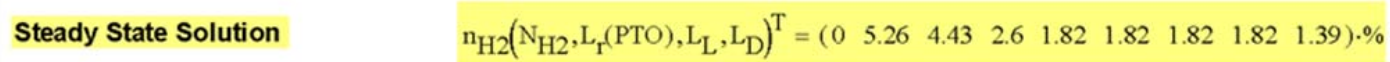

PTO $:=3 \quad \mathrm{Pu}_{\text {mass }}:=93 \cdot \mathrm{gm} \quad \mathrm{N}_{\mathrm{H} 2}:=\frac{\mathrm{PTO} \cdot \mathrm{Pu}_{\text {mass }} \cdot \mathrm{Ci}_{\mathrm{g} \cdot \mathrm{Pu}} \cdot \mathrm{Mev}_{\mathrm{dis}} \cdot \mathrm{G}_{\mathrm{H} 2}}{\mathrm{~N}_{\mathrm{A}}}=2.98 \times 10^{-7} \frac{\mathrm{mol}}{\mathrm{s}}$

$\mathrm{N}_{\mathrm{H} 2}:=\frac{\mathrm{PTO} \cdot \mathrm{Pu}_{\text {mass }} \cdot \mathrm{Ci}_{\mathrm{g} \cdot \mathrm{Pu}} \cdot \mathrm{Mev}_{\mathrm{dis}} \cdot \mathrm{G}_{\mathrm{H} 2}}{\mathrm{~N}_{\mathrm{A}}}=2.98 \times 10^{-7} \frac{\mathrm{mol}}{\mathrm{s}} \quad \mathrm{PTO} \cdot \mathrm{Pu}_{\text {mass }} \cdot 0.0064 \frac{\mathrm{watt}}{\mathrm{gm}}=1.79 \mathrm{~W}$

Steady State Solution $\quad \mathrm{n}_{\mathrm{H} 2}\left(\mathrm{~N}_{\mathrm{H} 2}, \mathrm{~L}_{\mathrm{r}}(\mathrm{PTO}), \mathrm{L}_{\mathrm{L}}, \mathrm{L}_{\mathrm{D}}\right)^{\mathrm{T}}=\left(\begin{array}{lllllllll}0 & 5.06 & 4.09 & 1.96 & 1.06 & 1.06 & 1.06 & 1.06 & 0.81\end{array}\right) \cdot \%$ 


$$
\begin{aligned}
& \text { PTO }:=1 \quad \mathrm{Pu}_{\text {mass }}:=105 \cdot \mathrm{gm} \quad \mathrm{N}_{\mathrm{H} 2}:=\frac{\mathrm{PTO} \cdot \mathrm{Pu}_{\mathrm{mass}} \cdot \mathrm{Ci}_{\mathrm{g} \cdot \mathrm{Pu}} \cdot \mathrm{Mev}_{\mathrm{dis}} \cdot \mathrm{G}_{\mathrm{H} 2}}{\mathrm{~N}_{\mathrm{A}}}=1.12 \times 10^{-7} \frac{\mathrm{mol}}{\mathrm{s}} \\
& \mathrm{N}_{\mathrm{H} 2}:=\frac{\mathrm{PTO} \cdot \mathrm{Pu}_{\text {mass }} \cdot \mathrm{Ci}_{\mathrm{g} . P \mathrm{Pu} \cdot \mathrm{Mev}_{\mathrm{dis}} \cdot \mathrm{G}_{\mathrm{H} 2}}}{\mathrm{~N}_{\mathrm{A}}}=1.12 \times 10^{-7} \frac{\mathrm{mol}}{\mathrm{s}} \quad \mathrm{PTO} \cdot \mathrm{Pu}_{\text {mass }} \cdot 0.0064 \frac{\text { watt }}{\mathrm{gm}}=0.67 \mathrm{~W}
\end{aligned}
$$

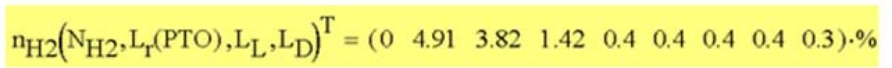

\section{Based on TRUCON Codes}

$$
\mathrm{L}_{\mathrm{L}}:=1.0 \cdot \frac{\mathrm{mol}}{\mathrm{s} \cdot \mathrm{mol}_{\mathrm{frac}}} \quad \mathrm{L}_{\mathrm{D}}:=3.7 \times 10^{-5} \frac{\mathrm{mol}}{\mathrm{s} \cdot \mathrm{mol}_{\mathrm{frac}}}
$$

Diffusivity

$$
\mathrm{L}_{\mathrm{r}}:=\left(\begin{array}{llllll}
1 & 4.76 \cdot 10^{-6} & 3.7 \cdot 10^{-6} & 1.0 & 1.0 & 1.0
\end{array}\right) \frac{\mathrm{mol}}{\mathrm{s} \cdot \mathrm{mol}_{\mathrm{frac}}}
$$

PTO $:=1$

$$
\mathrm{Pu}_{\text {mass }}:=88 \cdot \mathrm{gm}
$$

$$
\mathrm{N}_{\mathrm{H} 2}:=\frac{\text { PTO } \cdot \mathrm{Pu}_{\text {mass }} \cdot \mathrm{Ci}_{\mathrm{g} \cdot \mathrm{Pu}} \cdot \mathrm{Mev}_{\mathrm{dis}} \cdot \mathrm{G}_{\mathrm{H} 2}}{\mathrm{~N}_{\mathrm{A}}}=9.4 \times 10^{-8} \frac{\mathrm{mol}}{\mathrm{s}}
$$

Steady State Solution

$$
\mathrm{n}_{\mathrm{H} 2}\left(\mathrm{~N}_{\mathrm{H} 2}, \mathrm{~L}_{\mathrm{r}}, \mathrm{L}_{\mathrm{L}}, \mathrm{L}_{\mathrm{D}}\right)^{\mathrm{T}}=\left(\begin{array}{lllllllll}
0 & 4.77 & 4.77 & 2.8 & 0.25 & 0.25 & 0.25 & 0.25 & 0.25
\end{array}\right) \cdot \%
$$

\section{Pu-PTO-no liner-PFP-TRUCON}

$$
\begin{aligned}
& \text { Hydrogen generation rate } \quad \text { PTO :=1 } \quad \mathrm{L}_{\mathrm{L}}:=1.0 \cdot \frac{\mathrm{mol}}{\mathrm{s} \cdot \mathrm{mol}_{\mathrm{frac}}} \quad \mathrm{L}_{\mathrm{D}}:=3.7 \times 10^{-5} \frac{\mathrm{mol}}{\mathrm{s} \cdot \mathrm{mol}_{\mathrm{frac}}}
\end{aligned}
$$

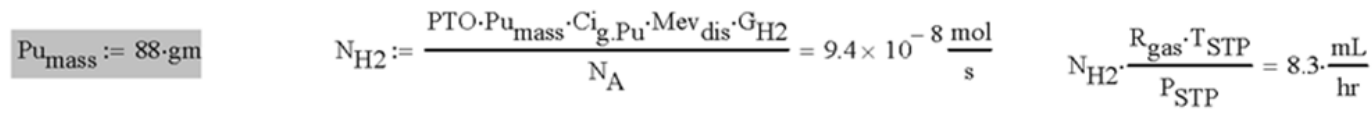

$$
\begin{aligned}
& \text { Diffusivity } \quad \mathrm{L}_{\mathrm{r}}:=\left(\mathrm{PTO} \cdot 1.0 \cdot 10^{-5} \mathrm{PTO} \cdot 4.67 \times 10^{-6} \mathrm{PTO} \cdot 1.1 \cdot 10^{-5} 1.0 \quad 1.01 .0\right) \frac{\mathrm{mol}}{\mathrm{s} \cdot \mathrm{mol}_{\mathrm{frac}}} \\
& \mathrm{P}_{\mathrm{H} 2}:=2.06 \cdot 10^{-9} \cdot \frac{\mathrm{cm}^{3} \cdot \mathrm{cm}}{\mathrm{s} \cdot \mathrm{cm}^{2} \cdot \mathrm{cm}-\mathrm{Hg}} \\
& \text { bag thickness } \quad \text { bag }_{\text {th }}:=\left(\begin{array}{lllllll}
14 & 14 & 14 & 14 & 14 & 14
\end{array}\right) \cdot \mathrm{mil} \\
& \text { bag height } \quad \operatorname{bag}_{\mathrm{ht}}:=\left(\begin{array}{llllll}
17 & 17.5 & 18 & 18.5 & 19 & 19.5
\end{array}\right) \cdot \text { in } \\
& \text { bag diameter } \quad \operatorname{bag}_{\text {dia }}:=\left(\begin{array}{llllll}
17 & 17.5 & 18 & 18.5 & 19 & 19.5
\end{array}\right) \cdot \text { in } \\
& \mathrm{L}_{\mathrm{L}}:=5.076 \cdot 10^{-5} \cdot \frac{\mathrm{mol}}{\mathrm{s} \cdot \mathrm{mol}_{\mathrm{frac}}} \quad \mathrm{L}_{\mathrm{D}}:=3.7 \times 10^{-6} \frac{\mathrm{mol}}{\mathrm{s} \cdot \mathrm{mol}_{\mathrm{frac}}} \quad \mathrm{L}_{\mathrm{r}}:=\mathrm{P}_{\mathrm{H} 2} \cdot \frac{\overrightarrow{\mathrm{bag}_{\mathrm{ht}} \cdot \pi \cdot \mathrm{bag}_{\mathrm{dia}}}}{\mathrm{bag}_{\mathrm{th}}} \mathrm{C}_{\mathrm{mol}}
\end{aligned}
$$




$$
\begin{aligned}
& \mathrm{Pu}_{\text {mass }}:=5 \cdot \mathrm{gm} \quad \mathrm{L}_{\mathrm{r}}=\left(1.05 \times 10^{-6} 1.12 \times 10^{-6} 1.18 \times 10^{-6} 1.25 \times 10^{-6} 1.32 \times 10^{-6} 1.39 \times 10^{-6}\right) \cdot \frac{\mathrm{mol}}{\mathrm{s} \cdot \mathrm{mol}} \mathrm{frac}_{\mathrm{fac}} \\
& \mathrm{N}_{\mathrm{H} 2}:=\frac{\mathrm{Pu}_{\text {mass }} \cdot \mathrm{Ci}_{\mathrm{g} . P u^{-M e v}}{ }_{\mathrm{dis}} \cdot \mathrm{G}_{\mathrm{H} 2}}{\mathrm{~N}_{\mathrm{A}}}=5.34 \times 10^{-9} \frac{\mathrm{mol}}{\mathrm{s}} \\
& \mathrm{N}_{\mathrm{H} 2} \cdot \frac{\mathrm{R}_{\text {gas }} \cdot \mathrm{T}_{\mathrm{STP}}}{\mathrm{P}_{\mathrm{STP}}}=0.5 \cdot \frac{\mathrm{mL}}{\mathrm{hr}} \\
& \mathrm{N}_{\mathrm{H} 2}:=5.42 \times 10^{-9} \frac{\mathrm{mol}}{\mathrm{s}}
\end{aligned}
$$

Steady State Solution $\quad \mathrm{n}_{\mathrm{H} 2}\left(\mathrm{~N}_{\mathrm{H} 2}, \mathrm{~L}_{\mathrm{r}}, \mathrm{L}_{\mathrm{L}}, \mathrm{L}_{\mathrm{D}}\right)^{\mathrm{T}}=\left(\begin{array}{lllllllll}0 & 2.85 & 2.34 & 1.85 & 1.39 & 0.96 & 0.55 & 0.16 & 0.15\end{array}\right) \cdot \%$

\section{TRUCON 6 bag heat sealed TRUCON codes -6 non-filtered bags (no}

$$
\text { Hydrogen gas permeability } \quad \mathrm{P}_{\mathrm{H} 2}:=9.6 \cdot 10^{-10} \cdot \frac{\mathrm{cm}^{3} \cdot \mathrm{cm}}{\mathrm{s} \cdot \mathrm{cm}^{2} \cdot \mathrm{cm} \_\mathrm{Hg}}
$$

$$
\begin{aligned}
& \text { Diffusivities } \quad \mathrm{L}_{\mathrm{L}}:=5.076 \cdot 10^{-5} \cdot \frac{\mathrm{mol}}{\mathrm{s} \cdot \mathrm{mol}_{\mathrm{frac}}} \quad \mathrm{L}_{\mathrm{D}}:=3.7 \times 10^{-6} \frac{\mathrm{mol}}{\mathrm{s} \cdot \mathrm{mol}_{\mathrm{frac}}} \\
& \mathrm{L}_{\mathrm{r}}:=\mathrm{P}_{\mathrm{H} 2} \cdot \frac{\overrightarrow{\mathrm{bag}_{\mathrm{ht}} \cdot \pi \cdot \mathrm{bag}_{\text {dia }}}}{\text { bag }_{\text {th }}} C_{\mathrm{mol}} \quad \mathrm{L}_{\mathrm{r}}=\left(4.9 \times 10^{-7} 5.2 \times 10^{-7} 5.5 \times 10^{-7} 5.8 \times 10^{-7} \quad 6.1 \times 10^{-7} 6.5 \times 10^{-7}\right) \cdot \frac{\mathrm{mol}}{\mathrm{s} \cdot \mathrm{mol}_{\text {frac }}} \\
& \mathrm{Pu}_{\text {mass }}:=5 \cdot \mathrm{gm} \quad \mathrm{N}_{\mathrm{H} 2}:=\frac{\mathrm{Pu}_{\text {mass }} \cdot \mathrm{Ci}_{\mathrm{g} . \mathrm{Pu}} \cdot \mathrm{Mev}_{\text {dis }} \cdot \mathrm{G}_{\mathrm{H} 2}}{\mathrm{~N}_{\mathrm{A}}}=5.34 \times 10^{-9} \frac{\mathrm{mol}}{\mathrm{s}} \quad \mathrm{N}_{\mathrm{H} 2} \cdot \frac{\mathrm{R}_{\mathrm{gas}} \cdot{ }^{\mathrm{T}} \mathrm{STP}}{\mathrm{P}_{\mathrm{STP}}}=0.5 \cdot \frac{\mathrm{mL}}{\mathrm{hr}}
\end{aligned}
$$

Based on total watts $\quad \mathrm{N}_{\mathrm{H} 2}:=5.42 \times 10^{-9} \frac{\mathrm{mol}}{\mathrm{s}}$

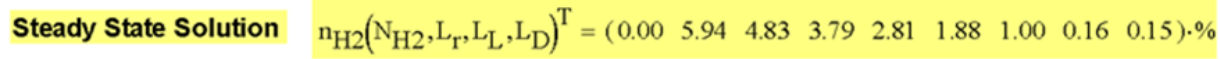

\section{TRUCON 3 bag with}

\section{filter}

Hydrogen gas permeability

$$
\begin{aligned}
& \mathrm{L}_{\mathrm{r}}:=\mathrm{P}_{\mathrm{H} 2} \cdot \frac{\overrightarrow{\mathrm{bag}_{\mathrm{ht}} \cdot \pi \cdot \mathrm{bag}_{\text {dia }}}}{\text { bag }_{\mathrm{th}}} C_{\mathrm{mol}} \\
& \mathrm{L}_{\mathrm{r}}=\left(4.91 \times 10^{-7} 5.21 \times 10^{-7} 5.51 \times 10^{-7} 5.82 \times 10^{-7} 6.14 \times 10^{-7} 6.47 \times 10^{-7}\right) \cdot \frac{\mathrm{mol}}{\mathrm{s} \cdot \mathrm{mol}} \mathrm{frac}
\end{aligned}
$$

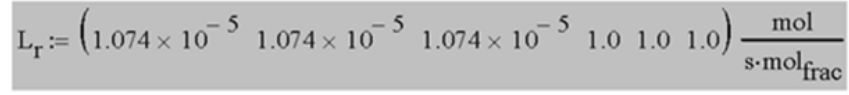




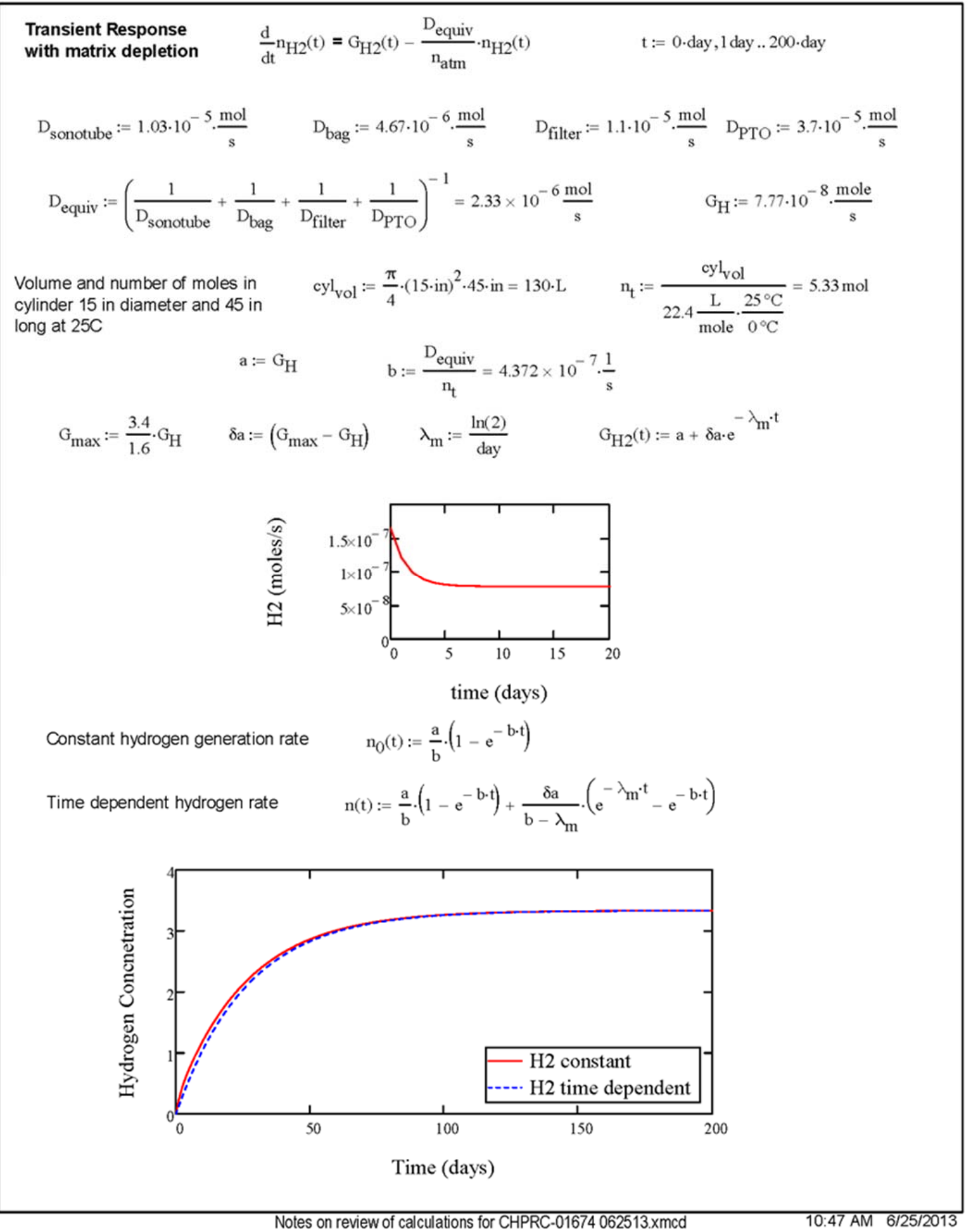

